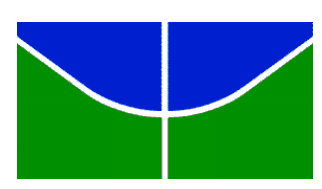

Universidade de Brasília

Instituto de Psicologia

Departamento de Psicologia Clínica

Programa de Pós-Graduação em Psicologia Clínica e Cultura

DO ESTADO DA ARTE AO DESENVOLVIMENTO DE UMA INTERVENÇÃO PARA EDUCAÇÃO PARA A APOSENTADORIA

LEONARDO MARTINS BARBOSA

Brasília, 2016 


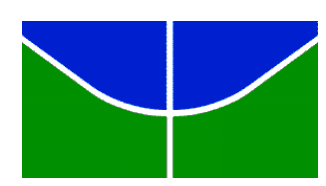

Universidade de Brasília

Instituto de Psicologia

Departamento de Psicologia Clínica

Programa de Pós-Graduação em Psicologia Clínica e Cultura

\title{
DO ESTADO DA ARTE AO DESENVOLVIMENTO DE UMA INTERVENÇÃO PARA EDUCAÇÃO PARA A APOSENTADORIA
}

Leonardo Martins Barbosa

\begin{abstract}
Texto submetido ao Programa de Pós-Graduação em Psicologia Clínica e Cultura da Universidade de Brasília, como parte dos requisitos necessários para a obtenção do título de Doutor em Psicologia.
\end{abstract}

Orientadora: Profa. Dra. Sheila Giardini Murta

Brasília, 2016 


\section{DO ESTADO DA ARTE AO DESENVOLVIMENTO DE UMA INTERVENÇÃO PARA EDUCAÇÃO PARA A APOSENTADORIA}

Banca Examinadora:

Profa. Dra. Sheila Giardini Murta

Universidade de Brasília - PCL/UnB

Presidente da Banca

Prof. Dr. Vicente Paulo Alves

Universidade Católica de Brasília - UCB

Membro Titular

Profa. Dra. Isolda de Araújo Günther

Universidade de Brasília - PST/UnB

Membro Titular

Profa. Dra. Laércia Abreu Vasconcelos

Universidade de Brasília - PPB/UnB

Membro Titular

Profa. Drạ. Maria Inês Gandolfo Conceição

Universidade de Brasília - PCL/UnB

Membro Titular

Profa. Dra. Carla Sabrina Antloga Universidade de Brasília - PCL/UnB

Membro Suplente 


\section{SUMÁRIO}

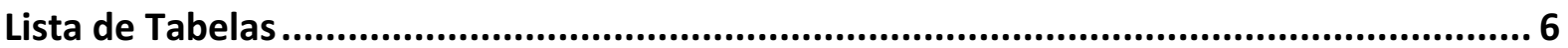

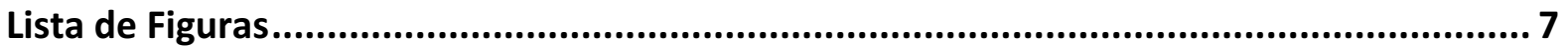

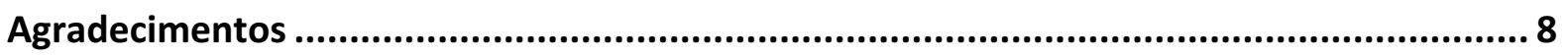

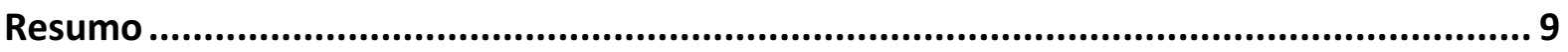

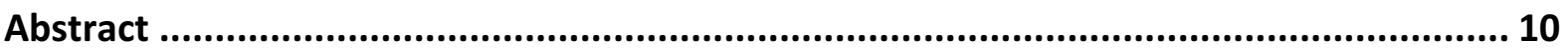

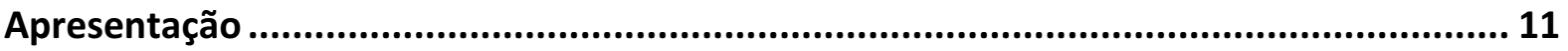

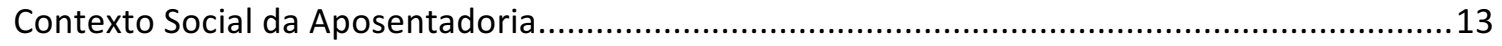

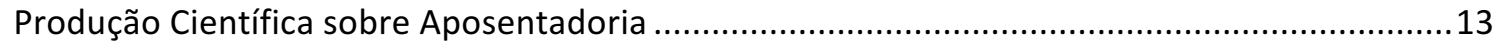

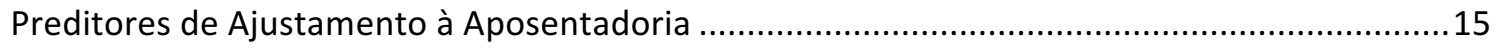

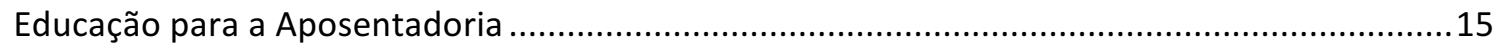

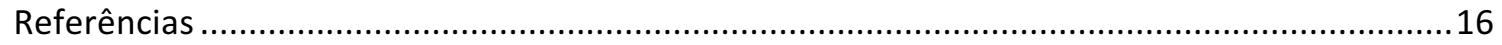

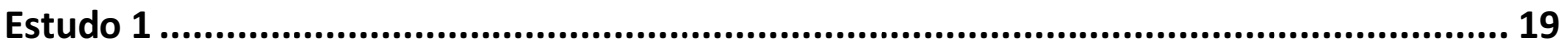

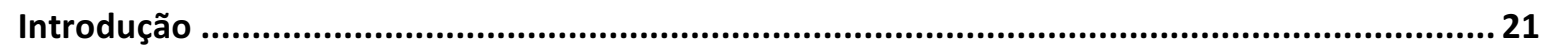

Método

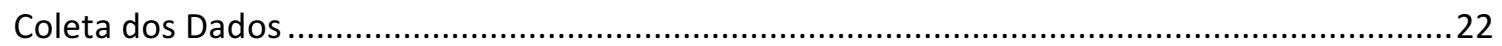

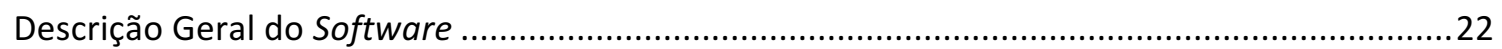

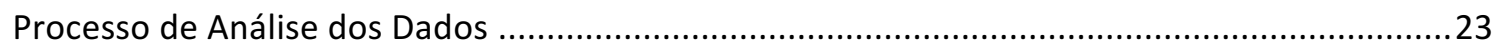

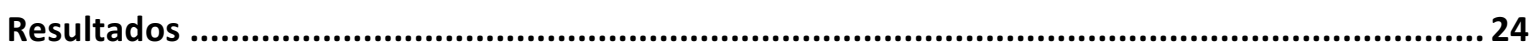

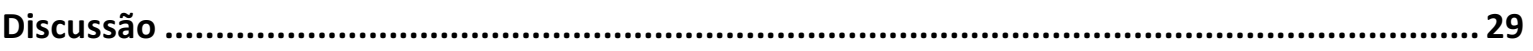

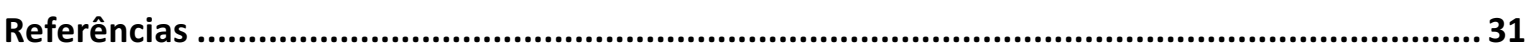

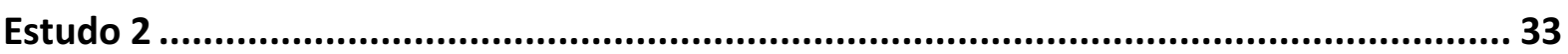

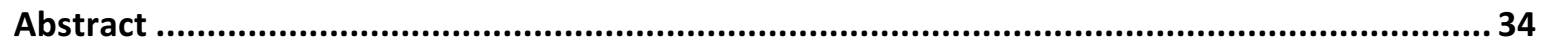

Method

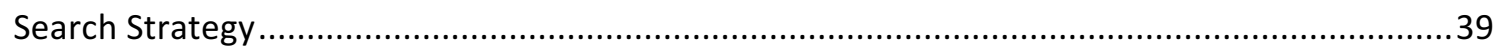

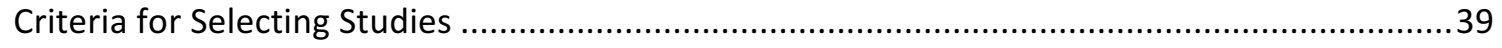

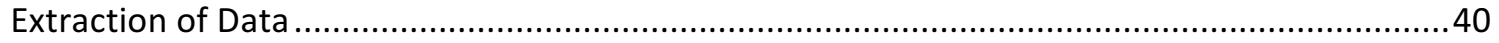

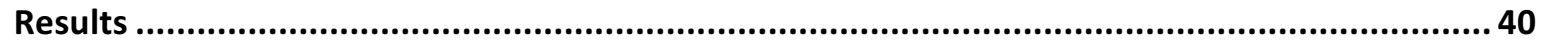

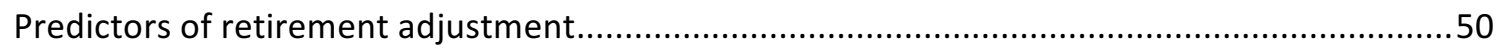

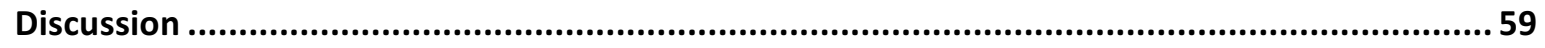

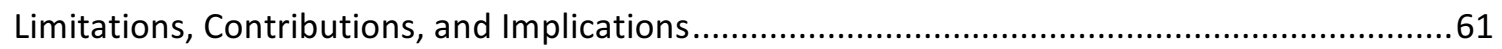

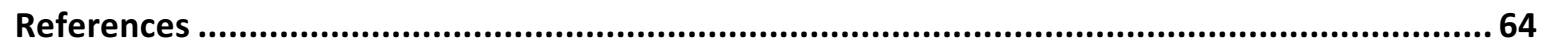

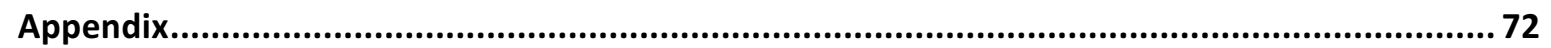

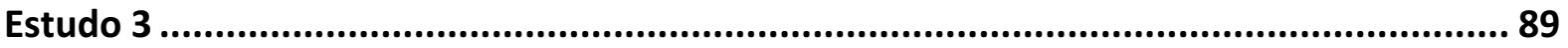

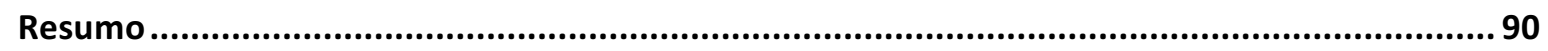

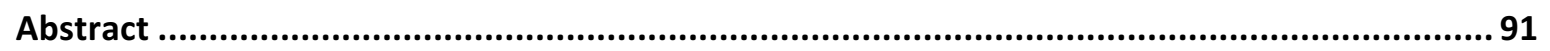

Desenvolvimento de Intervenções em Prevenção e Promoção em Saúde Mental......................93

Uma Abordagem Sistemática para o Desenvolvimento de Intervenções ...................................94

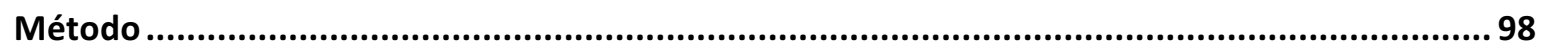

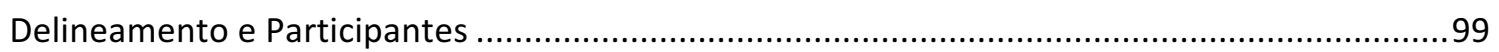

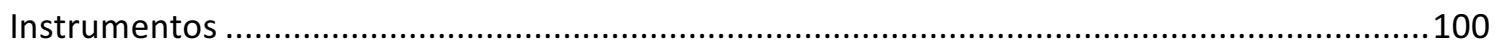

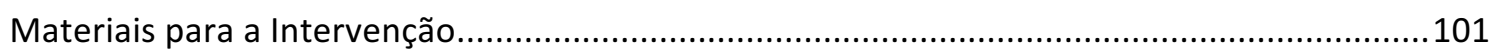

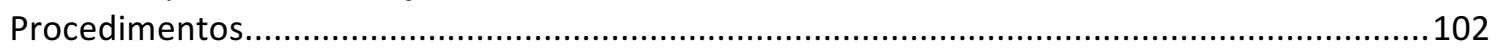

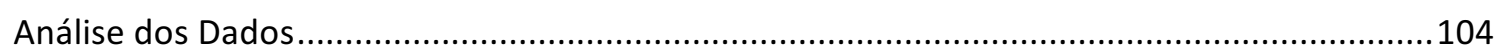

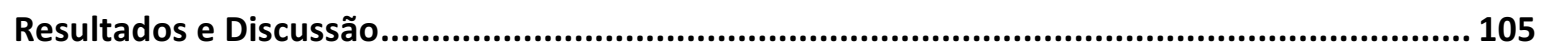

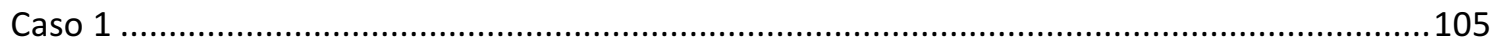




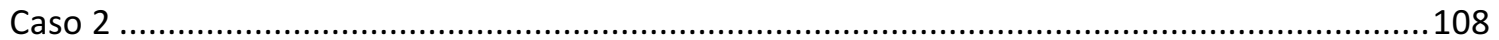

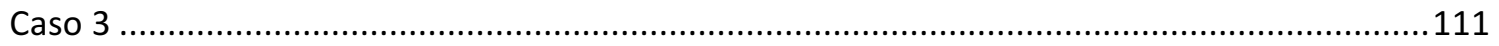

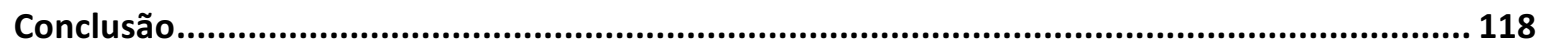

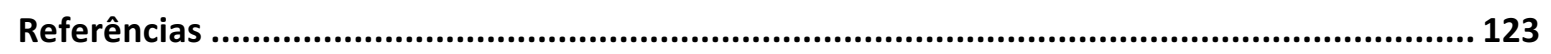




\section{LISTA DE TABELAS}

\section{Estudo 1}

Tabela 1

Tabela 2

Estudo 2

Tabela 1

Tabela 2

\section{Estudo 3}

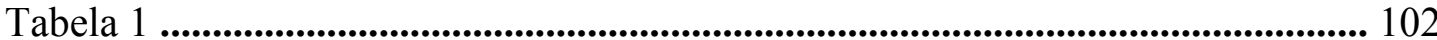

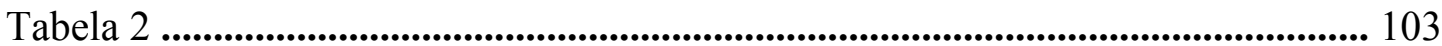

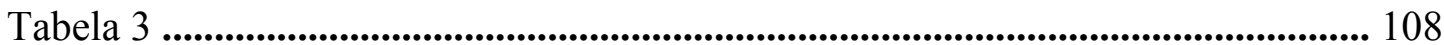

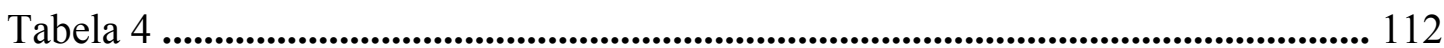

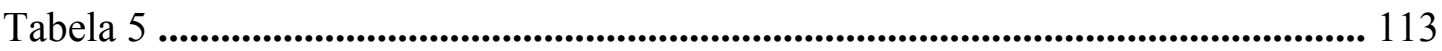

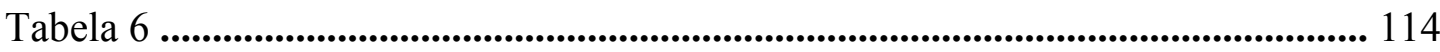

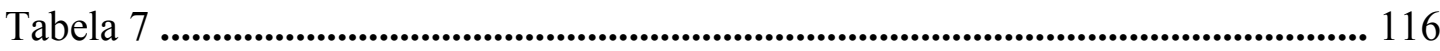




\section{LISTA DE FIGURAS}

\section{Estudo 1}

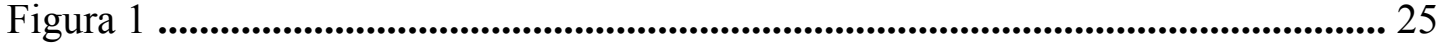

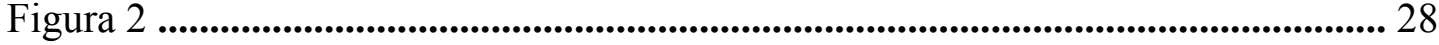

Figura 3 ........................................................................................................................................... 29

Estudo 2

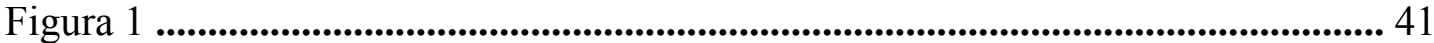

Estudo 3

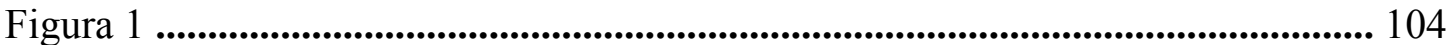

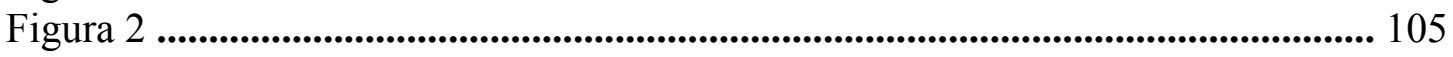




\title{
AGRADECIMENTOS
}

\author{
"Resta esse constante esforço para caminhar dentro do labirinto \\ Esse eterno levantar-se depois de cada queda \\ Essa busca de equilíbrio no fio da navalha \\ Essa terrível coragem diante do grande medo, e esse medo \\ Infantil de ter pequenas coragens.”
}

Vinícius de Moraes

Avaliando o haver, tenho a impressão de que se assemelha ao início. Nos primeiros anos de escola, assim como nos anos de graduação e nos anos de doutorado, o grande desafio foi olhar o mundo de frente, de pé e com os pés no chão. A cada novo avanço, uma tentativa ingênua de me desprender seguida de uma queda pedagógica, lembrete de que o ponto de partida e o ponto de chegada exigem que se tenha os pés no chão. Essa tese é o produto dos anos de educação, mas o haver dos anos de vida se resume na advertência de que é preciso manter os pés no chão. Portanto, agradeço em primeiro lugar à vida, que continua a me oferecer essa lição. Agradeço também:

Aos meus pais, por me mostrarem a vida de uma forma peculiar, mas que funcionou.

À Bárbara, por me disponibilizar uma lista de virtudes maior do que eu teria espaço para escrever. Seu amor e sua confiança (e sua revisão) estão presentes em cada linha e nas entrelinhas dessa tese. E na esperança de que era possível seguir adiante, mesmo quando nenhum sinal indicava isso.

À Andréia, por muitas vezes compartilhar do pouco que dispunha.

À Tia Nelci, por acreditar mesmo quando eu não sabia aonde ia.

Ao Leonel e ao Pedro, por mostrarem que existe algo além.

Aos amigos Jordana e Homero, Larissa, Samia, Karine, Luciana e Tiago, Fernanda e Alysson, Camila, Fabio, Virgínia, Rodolfo e Isabel, Rodrigo, Bruno, Artur, Diego, Ricardo e Michael por me mostrarem o valor da amizade.

Ao Fabio, pela inspiração de um irmão mais velho.

Ao Henrique Affonso, pela inspiração.

Aos colegas do Grupo de Estudos em Prevenção e Promoção em Saúde no Ciclo da Vida-GEPPSVida e ao Pedro, pela companhia, pelo estímulo indispensável e pelo suporte acadêmico.

Aos psicólogos Samita, Tahiná e Bernardo, pela mistura de amizade e profissionalismo.

Aos pesquisadores e professores que dedicam suas vidas à ciência e compartilham suas obras publicamente. São centenas de autores que não me conhecem e não me pediram nada em troca, mas a quem devo praticamente todo meu o conhecimento. Que a vida lhes retribua.

Por fim, à Sheila. É difícil colocar em palavras. Em 2005, anos antes de te conhecer, a leitura do livro Tornar-se Pessoa, do Carl Rogers, mudou meu caminho na Psicologia, na vida. Foi com o Rogers que entendi a necessidade de se manter os pés no chão para ser pleno. Sheila, você encarna e compartilha o que significa Tornar-se Pessoa. Não há palavras que permitam agradecer por isso. 


\section{RESUMO}

Ao descrever a incompletude da ontogenia humana, Paul Baltes apontou que a velhice é um fenômeno historicamente novo e, por isso, as sociedades ainda estão se adaptando a essa novidade. A expectativa de vida no mundo cresce continuamente e apresenta reflexos importantes, como a mudança do papel social da aposentadoria. Atualmente estima-se que um aposentado brasileiro viva cerca de 20 anos além da idade média da aposentadoria por tempo de serviço. Considerando esse cenário social, esta tese examina o contexto acadêmico da pesquisa sobre aposentadoria e apresenta uma intervenção para prevenir desfechos negativos e promover bem-estar na aposentadoria. O Estudo 1 teve o objetivo de investigar a publicação de artigos científicos sobre aposentadoria nos últimos 25 anos. Por meio da análise semântica das palavras-chave dos estudos da base de dados Scopus que mencionam a palavra retirement $(\mathrm{n}=18.362)$, identificou-se que as áreas mais desenvolvidas na pesquisa em aposentadoria são saúde e economia. O estudo das políticas públicas, que foca demandas sociais, apareceu como foco de interesse comum entre essas duas áreas. Entre os temas pouco pesquisados - portanto, ausentes dos resultados - está, por exemplo, a pesquisa em educação para a aposentadoria (EPA), que visa a preparar os trabalhadores para essa transição de vida. A análise dos dados deste estudo indica tendências de pesquisa e subáreas em que ainda precisamos avançar, delineando uma agenda de pesquisa baseada em evidências. Com o objetivo de avançar em uma dessas subáreas, a identificação dos determinantes psicossociais de uma boa aposentadoria, o Estudo 2 realizou uma revisão sistemática sobre preditores de ajustamento à aposentadoria. Foram investigadas sete bases de dados em busca de artigos publicados também nos últimos 25 anos. Foram encontrados 3.255 registros, mas restaram apenas 115 após a aplicação dos critérios de inclusão e exclusão. Os resultados indicaram quatro grupos de preditores descritos na literatura: Grupo 1, formado por preditores frequentemente estudados e com a maior proporção de efeitos positivos (p. ex., saúde e finanças); Grupo 2, também formado por preditores frequentemente estudados, mas com uma proporção de efeitos positivos menor do que aqueles do Grupo 1 (p. ex., EPA e espiritualidade); Grupo 3, formado por preditores pouco estudados e com elevada proporção de efeitos positivos (p. ex., metas e família); Grupo 4, formado por preditores com alta proporção de efeitos nulos ou mistos (p. ex., idade e sexo). A partir dessas evidências sobre os fatores que podem promover uma boa aposentadoria, o Estudo 3 apresenta a validação social de um estudo de casos múltiplos sobre uma intervenção para EPA. Foram realizadas três implementações em contextos diferentes, baseando-se na terapia de aceitação, que visa a promover flexibilidade, e no modelo prossocial, que visa a promover cooperação. Os resultados mostraram que a intervenção teve metas socialmente válidas, procedimentos socialmente aceitáveis e efeitos socialmente importantes. No entanto, a intervenção requer modificações como o uso de métodos mais dinâmicos, implementação das atividades com mais fidelidade ao planejamento e avaliações de follow-up para avaliar validade social dos efeitos ao longo do tempo. Em conjunto, os estudos apresentam o que tem sido feito na pesquisa sobre aposentadoria e oferecem contribuições para a área de EPA, em que as lacunas identificadas não contemplam a demanda social. Espera-se que estes resultados aumentem a compreensão sobre a vida da pessoa aposentada e, principalmente, contribuam para o desenvolvimento de políticas públicas que permitam a essa população desfrutar de uma qualidade de vida compatível com seus anos de dedicação e contribuição à sociedade.

Palavras-chave: aposentadoria; ajustamento à aposentadoria; educação para a aposentadoria. 


\begin{abstract}
When Paul Baltes described the incompleteness of human ontogeny architecture, he pointed out that aging is a new phenomenon in history. And the young old age has grown as fast as young ones use to grow. Events like epidemiological revolution and reduction in child birth mortality helped world life expectancy grow steadily and brought consequences such as changes in retirement social role. Nowadays a Brazilian retiree lives around 20 years over retirement due working years mean. In this social context, this thesis examines the academic context of the research on retirement and presents an intervention to prevent negative outcomes and promote well-being in retirement. Study 1 aims to investigate the publication of scientific articles on retirement over the past 25 years. Through the semantic analysis of database studies of keywords Scopus analysis that mention the word retirement $(n=18,362)$, is expected to identify the most developed and the less developed areas on retirement research. Data analysis indicates research trends and sub-areas we need to investigate further, outlining an evidence-based research agenda. Study 2 carries out a systematic review of predictors of adjustment to retirement aiming to summarize the psychosocial determinants of a good retirement. We investigated seven databases searching for articles published in the last 25 years. This search found 3,255 records, but only 115 remained after applying inclusion and exclusion criteria. The results indicated four groups of retirement adjustment predictors: Group 1, consisting of often studied predictors and the highest proportion of positive effects (eg., health and finance); Group 2 also consists of frequently studied predictors, but ones with a proportion of positive effects lower than those of Group 1 (e.g., retirement education and spiritual activities..); Group 3 consists of scarcely studied predictors with high proportion of positive effects (eg., goals and family..); and Group 4 consists of predictors with a high proportion of null or mixed effects (eg., age and sex). Based on this evidence, Study 3 describes the social validation of a multiple case study regarding an intervention focused on retirement education. Three implementations were carried out in different contexts. The intervention was based on the acceptance and commitment therapy, which aims to promote flexibility, and prosocial model, which aims to promote cooperation. The results show the intervention had socially valid goals, socially acceptable procedures and socially important effects. However, the intervention still requires improvement, such as applying dynamic methods, printed material formatting and implementing the intervention with higher fidelity. Considered together, these studies show what has been done on retirement research and offer contributions to the field of interventions, a socially relevant shortcoming. We hope these results increase the understanding of life in retirement and assist this population to enjoy a so deserved quality of life.
\end{abstract}

Keywords: retirement; retirement adjustment; retirement education. 


\section{APRESENTAÇÃO}

Esta é uma tese sobre aposentadoria e está organizada em três estudos. No primeiro e no segundo estudos, a prof ${ }^{\mathrm{a}}$. Sheila e eu avaliamos o contexto acadêmico das publicações científicas, realizando um exame abrangente da publicação de artigos sobre aposentadoria e revisando a literatura sobre ajustamento à aposentadoria. Então, em consonância com as evidências encontradas, no terceiro estudo avaliamos uma intervenção com o objetivo de educação para a aposentadoria (EPA). Embora este seja o resultado dos anos de estudo no doutorado, sua origem está em um trabalho anterior, iniciado no mestrado.

Durante o primeiro ano do curso de mestrado, estudei o tema estresse, pois era assim que muitos pacientes denominavam seu sofrimento. Sofrimento era uma experiência muito frágil para justificar comportamentos como crises de pânico, explosões de raiva ou insônia; estresse, no entanto, era motivo para que cônjuges, chefes e cardiologistas encaminhassem seus cônjuges, funcionários e pacientes para o consultório psicológico. Meu plano inicial visava a desenvolver uma intervenção grupal para tratamento do estresse, mas depois de um ano sucumbi às dificuldades do projeto: as pessoas estavam estressadas demais para se comprometerem com a intervenção. Então decidi estudar uma das ferramentas que planejava aplicar no enfrentamento do estresse, a Terapia de Aceitação e Compromisso (ACT; Hayes, Strosahl, \& Wilson, 1999).

Partindo do pressuposto de que o sofrimento emocional deriva de mecanismos psicológicos saudáveis, a $\mathrm{ACT}$ evita os problemas ontológicos relativos à natureza dos transtornos mentais (Frances, 2010) e enfatiza a funcionalidade da atividade humana. Sua integração a uma teoria básica sobre a cognição e a linguagem humanas (Hayes, BarnesHolmes, \& Roche, 2001) desenvolvida a partir de evidências experimentais permite tanto compreender o funcionamento psicológico quanto planejar intervenções que atuem com precisão nos mecanismos psicopatológicos. Ambas as dimensões, técnica e teórica, baseiam- 
se em pressupostos filosóficos comuns, o pragmatismo (Hayes, Hayes, \& Reese, 1988), conferindo coesão às diferentes dimensões do projeto básico de enfrentamento do sofrimento humano.

Em pouco menos de duas décadas de existência oficial, já foram produzidos cerca de 150 estudos controlados aleatorizados sobre ACT (ACBS publications, 2016). Abrangendo aplicações a contextos diversos - por exemplo, incluindo depressão, personalidade borderline, práticas parentais e estilo de vida em pacientes que tiveram câncer - as evidências mostram resultados pelo menos equivalentes às intervenções convencionais (Arch et al., 2012; Levin, Hildebrandt, Lilis, \& Hayes, 2012; Ruiz, 2012). A dissertação resultou em um trabalho teórico de organização dessas informações no formato de um manuscrito apresentando história, modelo, conceitos e evidências da ACT (Barbosa \& Murta, 2014) ao público brasileiro. Adicionalmente, também resultou em um trabalho empírico, a adaptação e o exame das propriedades de um instrumento psicométrico baseado na ACT, o Acceptance and Action Questionnaire-II (AAQ-II; Barbosa \& Murta, 2015).

Ao fim do mestrado, eu tinha à disposição uma abordagem que, ao mesmo tempo, me agradava pessoalmente e também se baseava em boas evidências empíricas. No entanto, a ACT era usada principalmente no contexto de tratamentos psicológicos e eu era um psicólogo clínico trabalhando principalmente em consultório, lidando com problemas instalados que já comprometiam a funcionalidade dos pacientes. Avaliei que ainda havia muito o que aprender com a prof ${ }^{a}$. Sheila e, para me aproximar dos seus temas de pesquisa, decidi seguir no doutorado pesquisando a aplicação da ACT no campo da aposentadoria. No mestrado, a ACT havia me surpreendido como um método amplo, coeso e efetivo. Como um método, no entanto, tratava-se de uma atividade meio. No doutorado, eu estava prestes a me surpreender com a relevância do tema aposentadoria e a demanda por métodos que favorecem a promoção de uma vida com mais qualidade na aposentadoria. 


\section{Contexto Social da Aposentadoria}

Durante a maior parte de sua história, a expectativa de vida média do ser humano foi de 25 anos (Hayflick, 2007). Na década de 1950, esse número já era cerca de 48 anos, enquanto hoje está em torno dos 65 anos (United Nations, 2013). Atualmente apenas o Japão tem mais de um terço da sua população formado por idosos; em 2050, no entanto, espera-se que mais de 60 países tenham pelo menos um idoso entre cada três habitantes (HelpAge, 2013). No Brasil, apenas entre 1980 e 2005, a expectativa de vida ao nascer saltou de 62 para 72 anos (Camarano \& Kanso, 2009). E as projeções indicam que o aumento da longevidade média deve continuar (Camarano \& Kanso, 2009; Global AgeWatch, 2013), aumentando a duração da aposentadoria, assim como o interesse nas condições de vida nesse período. $\mathrm{Na}$ União Europeia, por exemplo, um indivíduo vive em média entre duas e três décadas depois de se aposentar (European Comission, 2015). As consequências desse fenômeno são amplas, abrangendo desde riscos à estabilidade financeira - resultantes, por exemplo, da readaptação dos sistemas de seguridade social (Izerrougene, 2009) - a riscos à saúde - resultantes, por exemplo, das doenças crônicas, principais causas de mortalidade no Brasil (Brasil, 2015) e no mundo (World Health Organization, 2015). De modo geral, a aposentadoria é um estágio de vida que merece, e merecerá ainda mais, atenção especial.

\section{Produção Científica sobre Aposentadoria}

Nesse cenário, é importante verificar o que a ciência tem produzido sobre o tema. Por isso, o Estudo 1 desta tese tem o objetivo de investigar a publicação de artigos científicos sobre aposentadoria desde a década de 1990. Por meio de uma análise semântica das palavras-chave dos estudos da base de dados Scopus que mencionam a palavra retirement $(\mathrm{N}$ =18.362), espera-se identificar as áreas mais desenvolvidas e as áreas menos desenvolvidas na pesquisa sobre aposentadoria. Os resultados dessa investigação indicam duas grandes áreas de pesquisa sobre o tema: saúde e econômico-jurídico. A maior parte das publicações 
sobre o tema é feita nos Estados Unidos e na Europa, e as revistas com mais publicações abordam três temas: influência de fatores psicossociais sobre a saúde, aspectos econômicos da aposentadoria e implicações para políticas públicas. A comparação entre os termos mais comuns em 1991 e 2015 mostra, por exemplo, o crescimento da pesquisa sobre saúde física e mental e sobre os idosos mais velhos. Esses resultados podem indicar tendências de pesquisa e subáreas em que ainda precisamos avançar, delineando uma agenda de pesquisa baseada em evidências.

Entre os temas que recebem pouco destaque na publicação de artigos científicos sobre aposentadoria, encontra-se a EPA, área de pesquisa que visa ao desenvolvimento de intervenções com objetivo de favorecer a transição e o ajustamento à aposentadoria (Leandro-França, van Solinge, Henkens, \& Murta, 2016). Essa escassez é compatível com uma revisão recente sobre intervenções na área (Leandro-França, Murta, Hershey, \& Barbosa, 2016). Esta revisão buscou em 11 bases de dados eletrônicas artigos sobre EPA publicados em português, espanhol e inglês até 2014 que contivessem as palavras-chaves aposentadoria, intervenção, pré-aposentadoria, educação, aconselhamento, preparação e programa. Das 178 publicações encontradas, foram identificados apenas 11 estudos metodologicamente adequados, sendo que apenas cinco mencionavam as teorias que orientaram o desenvolvimento da intervenção. Esses resultados mostram que há demanda por intervenções de EPA; no entanto, percebemos que a diversidade de objetivos encontrada nessa amostra sinalizava a necessidade de organizar a literatura sobre os preditores de ajustamento à aposentadoria que deveriam ser promovidos nas intervenções de EPA. Do contrário, a própria efetividade das intervenções poderia ser comprometida pelo foco em variáveis pouco relevantes. 


\section{Preditores de Ajustamento à Aposentadoria}

Por isso, esta tese propõe como Estudo 2 uma revisão sistemática sobre preditores de ajustamento à aposentadoria. Foram investigadas sete bases de dados em busca de artigos publicados entre 1990 e 2014. Com o objetivo de identificar evidências sobre ajustamento à aposentadoria, foram pesquisados artigos com os descritores retirement $\mathrm{OU}$ retiring $\mathrm{OU}$ retire (relativos à aposentadoria) E scale OU measure OU instrument OU questionnaire (relativos a métodos de coleta de dados) E satisfaction OU adjustment OU well-being OU quality of life (relativos a variáveis critério). Foram encontrados 3.255 registros inicialmente, mas restaram apenas 115 após a aplicação dos critérios de inclusão e exclusão. Os resultados indicaram quatro grupos de preditores descritos na literatura: Grupo 1, formado por preditores frequentemente estudados e com a maior proporção de efeitos positivos (p. ex., saúde e finanças); Grupo 2, também formado por preditores frequentemente estudados, mas com uma proporção de efeitos positivos menor do que aqueles do Grupo 1 (p. ex., atividades de EPA e espiritualidade); Grupo 3, formado por preditores pouco estudados e com elevada proporção de efeitos positivos (p. ex., metas e família); Grupo 4, formado por preditores com alta proporção de efeitos nulos ou mistos (p. ex., idade e sexo).

\section{Educação para a Aposentadoria}

Considerando a carência de intervenções de EPA apresentada no Estudo 1 e a identificação de bons preditores de ajustamento à aposentadoria no Estudo 2, tornou-se oportuna a realização do Estudo 3 desta tese, que consiste em um estudo de casos múltiplos para validação social de uma intervenção sobre EPA. Foram realizadas três implementações em contextos diferentes. A intervenção se baseia na ACT, que visa a promover flexibilidade psicológica, a habilidade de manter ou mudar de comportamento, de maneira consciente e intencional, em função dos valores (Hayes, Luoma, Bond, Masuda, \& Lillis, 2006). Complementarmente, avaliou-se a adequação de uma abordagem que visa a otimizar esses 
resultados por meio da promoção de cooperação e coesão em grupos, o Modelo Prossocial (Wilson, Ostrom, \& Cox, 2013). Os resultados mostraram que a intervenção de EPA teve metas socialmente válidas, pois são flexíveis e atendem às necessidades individuais. Os procedimentos também foram considerados aceitáveis e resultaram em relatos de satisfação elevada pelos participantes; no entanto, ainda são necessárias modificações importantes, como o uso de métodos mais dinâmicos, formatação do material impresso e aumento da integridade na implementação do conteúdo e das atividades previstas. E os efeitos foram considerados socialmente importantes, havendo mudanças de comportamento em áreas da vida relevantes para os participantes e atendendo suas demandas iniciais.

Assim, os três estudos que compõem esta tese apresentam uma conexão que resulta em uma delimitação progressiva de objetivos: parte de uma avaliação abrangente sobre a produção acadêmica sobre aposentadoria, passa pela revisão dos preditores de ajustamento a essa fase da vida e se encerra na avaliação de uma intervenção que visa à promoção de uma vida melhor para os aposentados. Espera-se que estes resultados contribuam para aumentar a compreensão sobre a vida da pessoa aposentada e, principalmente, para que essa população possa desfrutar de uma qualidade de vida compatível com seus anos de dedicação e contribuição à sociedade.

\section{Referências}

ACBS Publications (2016). Association for Contextual Behavioral Science. Retirado de https://contextualscience.org/publications

Arch, J. J., Eifert, G. H., Davies, C., Vilardaga, J. C. P., Rose, R. D., \& Craske, M. G. (2012). Randomized clinical trial of cognitive behavioral therapy (CBT) versus acceptance and commitment therapy (ACT) for mixed anxiety disorders. Journal of Consulting and Clinical Psychology, 80(5), 750-765. 
Barbosa, L. M., \& Murta, S. G. (2014). Terapia de aceitação e compromisso: História, fundamentos, modelo e evidências. Revista Brasileira de Terapia Comportamental e Cognitiva, 16(3), 34-49.

Barbosa, L. M., \& Murta, S. G. (2015). Propriedades psicométricas iniciais do Acceptance and Action Questionnaire - II - versão brasileira. Psico-USF, 20(1), 75-85.

BRASIL. (2015). VIGITEL 2014: Vigilância de fatores de Risco para doenças crônicas por inquérito telefônico.

Camarano, A. A., \& Kanso, S. (2009). Perspectivas de crescimento para a população brasileira: Velhos e novos resultados. Rio de Janeiro: IPEA.

European Comission. (2015). The 2015 ageing report: Economic and budgetary projections for the 28 EU Member States (2013-2060). Luxembourg. Retirado de http://ec.europa.eu/economy finance/publications/

Frances, A. (2010). DSM in philosophyland: Curiouser and curiouser. Bulletin of the Association for the Advancement of Philosophy and Psychiatry, 17(2), 3-7.

HelpAge (2013). Global AgeWatch Index 2013: Insight report. London: HelpAge International.

Hayes, S. C., Barnes-Holmes, D., \& Roche, B. (2001). Relational frame theory - A postskinnerian account of human language and cognition. New York: Kluwer Academic/Plenum Publishers.

Hayes, S. C., Hayes, L. J., \& Reese, H. W. (1988). Finding the philosophical core: A review of Stephen C. Pepper's world hypotheses: A study in evidence. Journal of the Experimental Analysis of Behavior, 50(1), 97-111.

Hayes, S. C., Luoma, J. B., Bond, F. W., Masuda, A., \& Lillis, J. (2006). Acceptance and commitment therapy: Model, processes and outcomes. Behaviour Research and Therapy, 44(1), 1-25. 
Hayes, S. C., Strosahl, K. D., \& Wilson, K. G. (1999). Acceptance and commitment therapy: An experiential approach to behavioral change. New York: Guilford Press.

Hayflick, L. (2007). Biological aging is no longer an unsolved problem. Annals of the New York Academy of Sciences, 1100, 1-13. doi: 10.1196/annals.1395.001

Izerrougene, B. (2009). A macroeconomia da previdência social. Revista de Economia Contemporânea, 13(1), 31-46.

Leandro-França, C., Murta, S. G., Hershey, D. A., \& Barbosa, L. M. (2016). Evaluation of retirement planning programs: A qualitative analysis of methodologies and efficacy. Educational Gerontology. Publicação online. doi: 10.1080/03601277.2016.1156380

Leandro-França, C., van Solinge, H., Henkens, K., \& Murta, S. G. (2016). Effects of three types of retirement preparation program: A qualitative study of civil servants in Brazil. Educational Gerontology. Publicação online. doi: 10.1080/03601277.2016.1139969

Levin, M. E., Hildebrandt, M. J., Lillis, J., \& Hayes, S. C. (2012). The impact of treatment components suggested by the psychological flexibility model: A meta-analysis of laboratory-based component studies. Behavior Therapy, 43(4), 741-756.

Ruiz, F. J. (2012). Acceptance and commitment therapy versus traditional cognitive behavioral therapy: A systematic review and meta-analysis of current empirical evidence. International Journal of Psychology and Psychological Therapy, 12(2), 333357.

United Nations. (2013). World Population Ageing 2013. New York: United Nations.

World Health Organization. (2015). World Health Statistics 2015. Luxembourg: World Health Organization.

Wilson, D. S., Ostrom, E., \& Cox, M. E. (2013). Generalizing the core design principles for the efficacy of groups. Journal of Economic Behavior \& Organization, 90, S21-S32. doi: 10.1016/j.jebo.2012.12.010 


\section{ESTUDO 1}

O que estuda quem estuda aposentadoria? Tendências da publicação científica sobre aposentadoria*

* Este manuscrito será submetido à revista The Gerontologist na modalidade relato breve, para textos de até 2.500 palavras. 


\section{Resumo}

Quando as primeiras modalidades de aposentadoria surgiram, há cerca de um século e meio, a população de idosos alcançava proporções inéditas na história. A criação dos sistemas de pensão foi uma solução para lidar com os idosos pobres, de saúde debilitada e inaptos para continuar trabalhando. Hoje, no entanto, a necessidade de saúde e condições financeiras, demandas básicas, coexiste com novas demandas, como a promoção de uma vida de qualidade na aposentadoria. Para avaliar como a ciência tem contribuído para melhorar esse cenário, este artigo teve o objetivo de investigar a publicação de artigos científicos sobre aposentadoria nos últimos 25 anos. Artigos da base de dados Scopus que mencionam a palavra retirement $(\mathrm{N}=18.362)$ foram avaliados e os resultados mostram que países da América do Norte e Europa estão entre os mais produtivos. A publicação sobre aposentadoria está associada com investimento nacional em pesquisa e desenvolvimento $(r=0,84)$, mas tem pouca relação com a proporção nacional de idosos $(r=-0,06)$. Saúde e economia são as áreas mais pesquisadas e estão conectadas pelo interesse comum no tema políticas públicas. Entre os autores da área de saúde, a pesquisa sobre saúde na aposentadoria resulta indiretamente do interesse primário pela saúde no envelhecimento. Entre os temas pouco pesquisados portanto, ausentes dos resultados - está, por exemplo, a pesquisa em educação para a aposentadoria, que visa a preparar os trabalhadores para essa transição de vida. Propõe-se como agenda de pesquisa o desenvolvimento de estudos sobre políticas públicas, para promover a coesão entre as principais áreas, e sobre temas diversos de saúde e economia, para ampliar o alcance do conhecimento acadêmico sobre aposentadoria.

Palavras-chave: aposentadoria; bibliometria; iramuteq; análise semântica. 


\section{Introdução}

Historicamente, a vida profissional costumava durar tanto quanto a capacidade física dos trabalhadores (Thane, 2006). Na segunda metade do século 19, com a formação de uma população crescente de idosos incapazes de trabalhar, pobres e com saúde frágil, a Europa testemunhou as primeiras mudanças em larga escala dessa realidade. A partir da Inglaterra, as primeiras modalidades de aposentadoria se espalharam para a Europa ocidental, Oceania e América do Norte. Na primeira metade do século 20, países da América Latina adotaram sistemas de seguridade social com grande discrepância entre contribuição e benefícios, que se mostrariam insustentáveis com o envelhecimento da população (Tuesta, 2011). Na África, a seguridade social tem sido bastante limitada, excluindo principalmente mulheres e trabalhadores informais (Darkwa \& Mazibuko, 2002).

Atualmente as situações que ensejaram o surgimento da aposentadoria, velhice e pobreza, coexistem com novas demandas. De forma geral, os sistemas governamentais de seguridade social estão em condições insustentáveis (Thane, 2006) e a prevalência de doenças crônicas não-transmissíveis ameaça a qualidade de vida na aposentadoria (United Nations, 2013). Ao mesmo tempo, o descuido de outros preditores de um bom ajustamento à aposentadoria - como lazer, suporte social e autonomia na decisão de se aposentar - pode preservar riscos à qualidade da vida na aposentadoria (Barbosa, Monteiro, \& Murta, 2016).

Nesse contexto, a ciência pode ser uma fonte relevante para atender à demanda social. Por isso, este estudo tem o objetivo de investigar a publicação de artigos científicos sobre aposentadoria nos últimos 25 anos. Essa investigação pode revelar como se organiza o campo de pesquisa sobre aposentadoria, delineando a trajetória e a temática da publicação científica na área. Com uma visão panorâmica, seria mais fácil adotar estratégias de desenvolvimento 
científico compatíveis com a demanda social, favorecendo a promoção de uma vida melhor na aposentadoria.

\section{Método}

\section{Coleta dos Dados}

Os dados foram extraídos da base eletrônica Scopus. A busca foi realizada de acordo com os seguintes critérios: (1) documentos do tipo artigo ou revisão (2) publicados entre os anos de 1991 e 2015 (3) contendo o termo retirement (4) nos campos título, resumo ou palavra-chave. De acordo com o planejamento inicial, a busca também seria realizada na base de dados Web of Science. No entanto, há diferenças em relação ao tipo de informação e à formatação dos dados de cada base, dificultando a análise conjunta dos dados. Para viabilizar a análise, apenas a Scopus foi utilizada.

\section{Descrição Geral do Software}

Os dados foram analisados por meio do programa Iramuteq, versão 0.7 alpha 2 . O Iramuteq é um tipo de análise de texto assistida por computador (Smallman, 2015), categoria de programas que oferece uma alternativa à análise de conteúdo tradicional. O funcionamento dos programas computadorizados se baseia em um modelo linguístico em que o significado das palavras resulta da sua organização e distribuição ao longo do texto. No caso do Iramuteq, as palavras relevantes são identificadas por meio de filtros gramaticais e estatísticos e comparadas a um dicionário interno. Esse processo não extrai significado do texto, mas oferece padrões de palavras que o pesquisador deve comparar com o texto original para elaborar suas conclusões (Smallman, 2015).

O uso de métodos computadorizados apresenta vantagens e desvantagens em relação à análise de conteúdo tradicional (Smallman, 2015). Entre as vantagens, permitem a realização de análises rápidas de grandes volumes de dados rapidamente; redução dos 
problemas causados pela amostragem, que frequentemente é desnecessária; redução da interferência do viés do pesquisador; e eliminação da checagem de categorias entre avaliadores, pois o texto é analisado sem codificação prévia. Entre as desvantagens, os programas apresentam algumas limitações: a influência do algoritmo pode gerar resultados que distorcem o contexto textual original, a busca por diferenças estatisticamente significativas pode superestimar a diferença entre classes de palavras e as análises podem falhar em identificar perspectivas com menor representatividade. Por isso os resultados precisam ser interpretados no contexto do material original.

\section{Processo de Análise dos Dados}

A análise dos dados seguiu o método desenvolvido por Lahlou e descrito por Smallman (2015) para realizar análises textuais assistidas por computador. O método adotado se dividiu em três etapas: coleta dos dados, modelagem e análise. Na coleta, o banco de dados de texto, chamado de corpus, foi preparado para a análise. Na modelagem, foram escolhidos filtros que permitem selecionar entre formas ativas (substantivos, adjetivos, verbos e advérbios) ou complementares (pronome e preposições, por exemplo), indicando as palavras significativas que foram extraídas do corpus e a frequência das formas textuais. Na etapa de análise, a categorização automática realizada pelo programa gerou classes de palavras passíveis de interpretação.

A principal categorização fornecida pelo Iramuteq é a Classificação Hierárquica Descendente (CHD), análise em que se agrupam segmentos de texto com semelhanças léxicas em uma grande classe. $\mathrm{O}$ algoritmo compara a frequência esperada e a frequência observada das palavras e esse conjunto em duas classes, repetindo esse processo até finalizar em duas classes que apresentam a maior diferença possível entre si. Cada classe apresenta suas palavras ordenadamente, de acordo com a força da associação entre a palavra e a classe. 
Esse é o resultado que foi interpretado por meio da atribuição de sentido às classes ou a subgrupos de palavras em cada classe.

Também foram realizadas análises de especificidade e de similitude. A análise de especificidade organiza o corpus de acordo com variáveis escolhidas pelo pesquisador. Neste estudo, as variáveis ano de publicação, país de publicação, autores e revista foram escolhidas para realizar as análises de especificidade. A análise de similitude organiza as palavras correlacionadas no corpus, indicando grupos compostos por termos que se repetem em conjunto. Para viabilizar a visualização dos resultados, essa análise considerou apenas as 50 palavras mais comuns.

\section{Resultados}

A busca dos dados na Scopus encontrou 18.362 registros. Deste total, apenas $47 \%$ dos registros continham palavras-chave atribuídas pelos autores, enquanto $66 \%$ dos textos continham palavras-chave indexadas, que são atribuídas pela base de dados. Por isso, foi escolhido como corpus o conjunto das palavras-chave indexadas.

A publicação anual sobre aposentadoria em 2015 foi 3,9 vezes superior à publicação em 1991, trajetória apresentada na Figura 1. Esse crescimento foi similar ao registrado na publicação anual total da Scopus, que passou de 479.480, em 1991, para 1.657.210, em 2015, um crescimento de 3,5 vezes. 


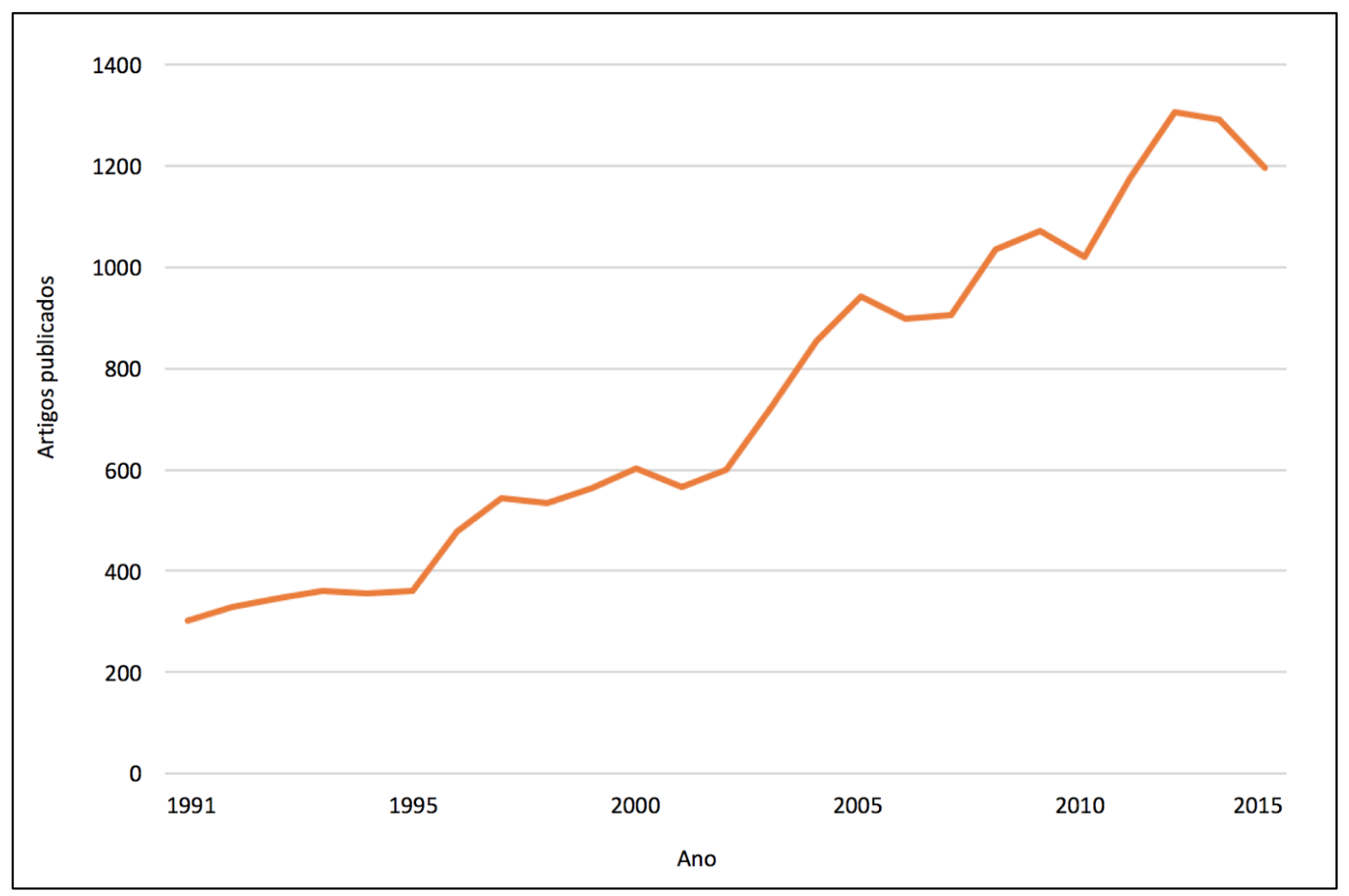

Figura 1. Número de artigos e revisões registrados anualmente na base de dados Scopus entre 1991 e 2015.

A Tabela 1 apresenta a distribuição das publicações sobre aposentadoria de acordo com o país de origem, os autores e a revista onde foi publicado o estudo. Entre os países de origem, os EUA aparecem em primeiro lugar com 4,6 vezes mais publicações do que o Reino Unido, segundo colocado. Entre as revistas, o Journal of Gerontology, Series B, que publica artigos com foco interdisciplinar, ocupa a primeira colocação. De acordo com o foco temático informado nos websites das revistas (ver Apêndice), há nove periódicos com foco interdisciplinar (abrangem principalmente saúde pública, ciências sociais e psicologia) e oito com foco econômico, sendo que revistas de ambos as áreas também contemplam a produção sobre políticas públicas. Entre os autores, o médico norte-americano Kenneth Langa, da Universidade de Michigan, é o mais produtivo, publicando sobre epidemiologia e impacto de doenças crônicas entre idosos, principalmente Alzheimer e outras demências. De acordo com os websites dos autores ou de suas instituições (ver Apêndice), o tema de pelo menos nove dos 20 autores mais produtivos é o impacto de fatores epidemiológicos e psicossociais sobre 
a saúde, enquanto oito pesquisam os aspectos econômicos da aposentadoria. $\mathrm{Na}$ área econômica, os autores declaram que a aposentadoria é um tema de pesquisa; na área de saúde, no entanto, os autores relatam interesse no tema envelhecimento. Como os processos de envelhecimento e aposentadoria coincidem, quem pesquisa saúde no envelhecimento pode acabar pesquisando também, de forma indireta, saúde na aposentadoria.

Tabela 1

Distribuição dos 20 países, autores e revistas com maior número de artigos e revisões sobre aposentadoria registrados na base de dados Scopus entre 1991 e 2015

\begin{tabular}{|c|c|c|c|c|c|c|}
\hline Colocação & País & $\mathrm{n}$ & Autor & $\mathrm{n}$ & Revista & $\mathrm{n}$ \\
\hline 1 & EUA & 6347 & Langa, K.M. & 84 & $\begin{array}{l}\text { Journals of Gerontology Series B } \\
\text { Psychological Sciences and Social } \\
\text { Sciences }\end{array}$ & 185 \\
\hline 2 & Reino Unido & 1378 & VanDerhei, J. & 49 & Benefits Quarterly & 151 \\
\hline 3 & Alemanha & 961 & Henkens, $\mathrm{K}$. & 48 & Social Security Bulletin & 146 \\
\hline 4 & Austrália & 815 & Copeland, C. & 48 & Gerontologist & 142 \\
\hline 5 & Canadá & 755 & Glymour, M.M. & 43 & Ageing and Society & 137 \\
\hline 6 & França & 621 & Kivimaki, M. & 42 & EBRI Issue Brief & 131 \\
\hline 7 & Holanda & 459 & Vahtera, J. & 33 & Research on Aging & 126 \\
\hline 8 & Suécia & 370 & Resnick, B. & 33 & $\begin{array}{l}\text { Journal of the American } \\
\text { Geriatrics Society }\end{array}$ & 112 \\
\hline 9 & Espanha & 312 & lams, H.M. & 31 & Journal of Public Economics & 96 \\
\hline 10 & Finlândia & 284 & Zins, M. & 30 & Modern Healthcare & 94 \\
\hline 11 & Itália & 283 & Fronstin, $\mathrm{P}$. & 27 & Journal of Aging and Social Policy & 86 \\
\hline 12 & Japão & 229 & Mitchell, O.S. & 27 & $\begin{array}{l}\text { International Journal of Aging } \\
\text { and Human Development }\end{array}$ & 85 \\
\hline 13 & China & 227 & Lahelma, E. & 26 & Journal of Medical Economics & 85 \\
\hline 14 & Dinamarca & 198 & Pentti, J. & 25 & Social Science and Medicine & 81 \\
\hline 15 & Suíça & 196 & Schofield, D.J. & 25 & $\begin{array}{l}\text { Journal of Financial Counseling } \\
\text { and Planning }\end{array}$ & 76 \\
\hline 16 & Brasil & 177 & Avendano, M. & 25 & Educational Gerontology & 74 \\
\hline 17 & Israel & 172 & Paganini-Hill, A. & 24 & Business and Health & 73 \\
\hline 18 & Bélgica & 143 & Goldberg, M. & 23 & Journal of Aging and Health & 73 \\
\hline 19 & N. Zelândia & 124 & Gustman, A.L. & 22 & Gerontologie Et Societe & 72 \\
\hline 20 & Noruega & 122 & Clark, R.L. & 22 & $\begin{array}{l}\text { Journal of Pension Economics } \\
\text { and Finance }\end{array}$ & 69 \\
\hline
\end{tabular}

A Tabela 2 apresenta as palavras-chave mais comuns nos registros encontrados. Em 1991, destaca-se um grande conjunto de palavras relativas aos aspectos econômicos da aposentadoria, como economics, pension, employment, organization and management, 
financial management, investment e health insurance. Em 2015, no entanto, ocorrem apenas três termos relacionados a esse grupo, economics, employment e income. Por outro lado, destaca-se um grupo de termos relativos à saúde e à pesquisa em saúde, composto por major clinical study, controlled study, psychology, depression e health status. Também aparece como uma forma comum a expressão aged 80 and over, referente a uma faixa etária ausente da classificação de 1991.

Tabela 2

Comparação entre as palavras-chave mais comuns nos artigos e revisões sobre aposentadoria publicados em 1991 e em 2015

\begin{tabular}{|c|c|c|c|}
\hline Termos & 1991 & Termos & 2015 \\
\hline$\overline{\text { age }}$ & 239 & $\overline{\text { age }}$ & 486 \\
\hline retirement & 198 & retirement & 343 \\
\hline economics & 69 & major_clinical_study & 135 \\
\hline pension & 64 & controlled_study & 106 \\
\hline middle_age & 51 & statistics_and_numerical_data & 93 \\
\hline socioeconomic & 45 & socioeconomic & 83 \\
\hline homes_for_the_aged & 44 & very_elderly & 82 \\
\hline support & 37 & psychology & 78 \\
\hline financial_management & 32 & depression & 76 \\
\hline employment & 30 & 80_and_over & 72 \\
\hline organization_and_management & 28 & health_status & 67 \\
\hline age_factors & 26 & employment & 62 \\
\hline insurance & 25 & adult & 62 \\
\hline legal_aspect & 24 & economics & 61 \\
\hline investment & 24 & questionnaire & 58 \\
\hline health_insurance & 21 & longitudinal_study & 55 \\
\hline questionnaire & 20 & cohort_analysis & 52 \\
\hline adult & 20 & young_adult & 52 \\
\hline psychological_aspect & 20 & income & 47 \\
\hline $\operatorname{tax}$ & 19 & risk_factor & 47 \\
\hline
\end{tabular}

A Figura 2 apresenta o resultado da CHD das palavras-chave indexadas. Como essa análise organiza as classes a partir de um algoritmo, é natural que haja sobreposição semântica entre palavras de classes distintas. Observam-se sete áreas temáticas na pesquisa sobre aposentadoria: Classe 1 - abrange $11,7 \%$ das palavras e se refere à economia e aos 
aspectos legais, com termos como legal aspects, employee retirement e; Classe 2 - abrange $15,4 \%$ das palavras e se refere aos determinantes psicossociais biomédicos, com termos como smoke, hypertension e obesity; Classe 3 - abrange 13,6\% das palavras e se refere à saúde no trabalho, com termos como absenteeism, occupational diseases e cost of illness; Classe 4 abrange $15,4 \%$ das palavras e se refere aos determinantes sociodemográficos, incluindo termos como socioeconomics, income e age; Classe 5: abrange 16,2\% das palavras e se refere aos determinantes psicossociais psicológicos, incluindo termos como psychological, adaptation e personal satisfaction; Classe 6: abrange $16,1 \%$ das palavras e se refere a sistemas de saúde, incluindo termos como physician, nurse e medical education; e Classe 7 abrange $11,7 \%$ das palavras e se refere aos aspectos demográficos, incluindo termos como pension system, eurasia, e aging population.

Classe 1: Legal aspect, employee retirement, health insurance, health benefits, employee, United States, insurance, pension, managed care program, liability.

Classe 7: Pension system, Eurasia, elderly population, aging population, social policy, Europe, labour market, economic factors, demographic factors, North America.

Classe 2: Major clinical study, controlled study, body mass, smoke, diabetes mellitus, hypertension, obesity, risk factor, prevalence, disease association.

Classe 3: Absenteeism, disability evaluation, occupational disease, work capacity, work disability, major clinical study, cost of illness, occupational health, sick leave, medical leave.

Classe 4: Socioeconomic factors, socioeconomics, health status, income, statistic, age, longitudinal studies, statistical model, health survey, sex factors.

Classe 5: Psychological, adaptation, age, home for the aged, adaptive behavior, psychological aspect, personal satisfaction, housing for the elderly, attitude, human relation.

Classe 6: History, 20th century, physician, manpower, nurse, medical education, medical, attitude of health personnel, personnel management, nursing staff.

Figura 2. Classes temáticas resultantes da Classificação Hierárquica Descendente das palavras-chave indexadas. Para facilitar a visualização, apenas as 10 palavras mais frequentes em cada classe foram apresentadas.

A Figura 3 apresenta a análise de similitude das palavras-chave. Foram identificados dois grandes agrupamentos de palavras em torno dos termos retirement e age. O grupo associado a retirement remete aos aspectos econômicos, como economics, employment, 
pension e income; e o grupo associado a age remete aos aspectos de saúde e seus determinantes, como major clinical study, health status, psychological e risk factors.

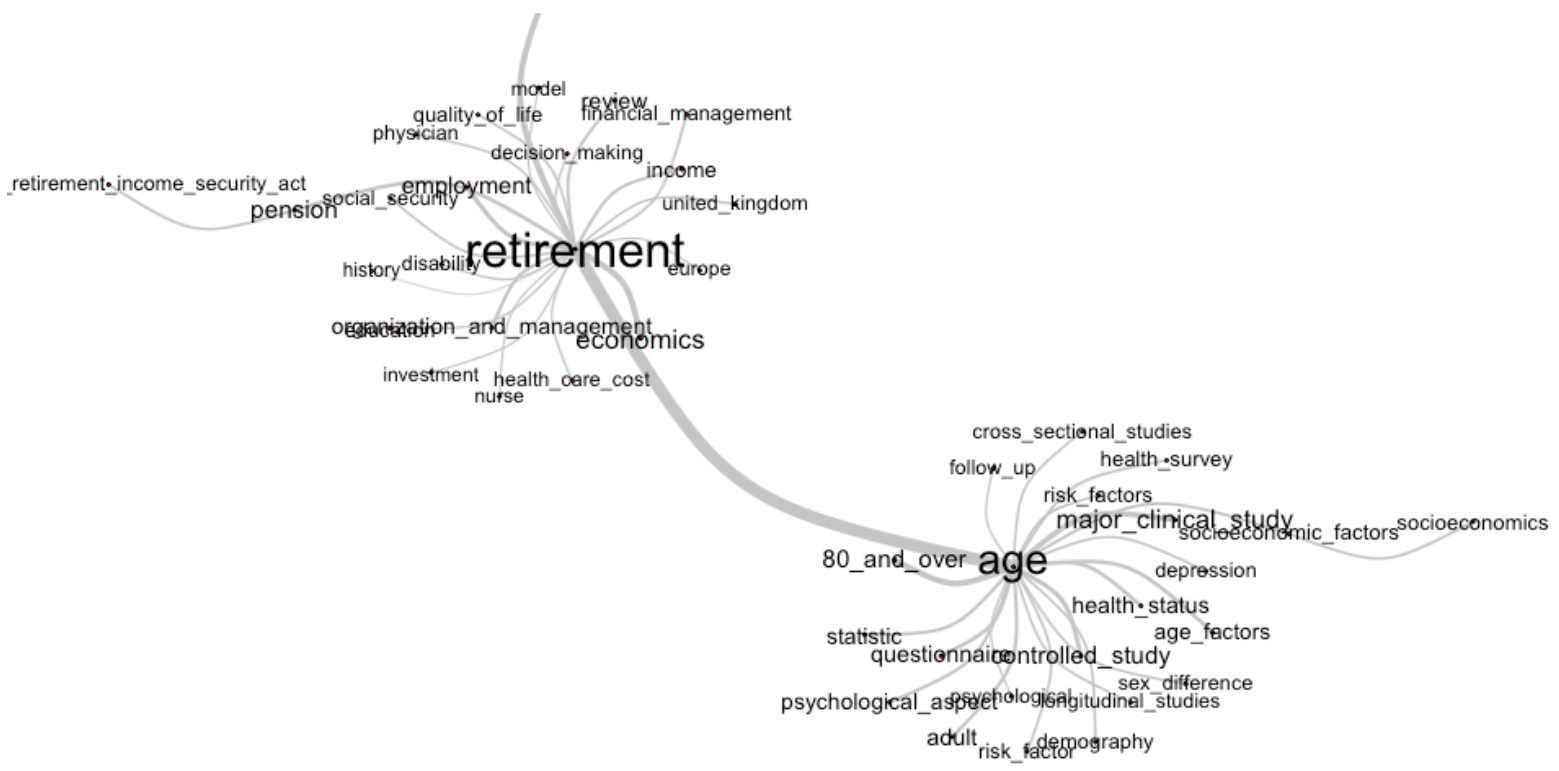

Figura 3. Grupos de palavras correlacionadas identificado na análise de similitude.

Além do que mostram as análises, também é relevante identificar temas que as análises não mostram. Por exemplo, a pesquisa sobre educação para a aposentadoria, campo que visa a facilitar a transição e favorecer o ajustamento do trabalhador à vida na aposentadoria, tem papel secundário. As expressões desenvolvimento de programas, programas educativos e estudos de intervenção ocorreram apenas 115 vezes.

\section{Discussão}

Este estudo teve como objetivo investigar a publicação de artigos científicos sobre aposentadoria nos últimos 25 anos. Para isso, foram selecionadas as publicações indexadas na base de dados eletrônica Scopus. A análise das palavras-chave indexadas mostra como a publicação sobre aposentadoria se organiza e indica os principais temas de pesquisa na área.

A publicação científica sobre aposentadoria cresceu em um ritmo semelhante ao crescimento da publicação científica geral. Entre os países que mais publicam na área, 14 estão localizados na América do Norte e Europa, apenas um na América Latina (Brasil) e 
nenhum na África. Essa distribuição geográfica não parece casual: há uma correlação de 0,84 entre a publicação em aposentadoria e o investimento nacional em pesquisa e desenvolvimento (UNESCO, 2013). Por outro lado, há uma correlação de $-0,06$ entre a publicação em aposentadoria e a população relativa de idosos (WHO Statistics, 2015). Esses dados mostram que a produção sobre aposentadoria reflete o investimento financeiro em pesquisa, mas não a demanda social do país, que é bastante variável. Por exemplo, enquanto a população africana ainda não completou sua transição demográfica (Darkwa \& Mazibuko, 2002), um em cada três japoneses já é idoso (HelpAge, 2013). Regiões com baixa produção ficam vulneráveis aos riscos da importação do conhecimento, como a adaptação cultural inadequada ou ausente (Castro, Barrera Jr., \& Steiker, 2010). Atender às diferentes demandas sociais sobre aposentadoria e envelhecimento, portanto, dependerá de políticas científicas regionais que encorajam a produção de conhecimento focado nas especificidades contextuais.

De forma geral, o campo de pesquisa sobre aposentadoria se divide em duas grandes áreas temáticas. As análises das revistas e dos autores mais produtivas, assim como a análise de similitude, identificam principalmente uma grande área sobre temas em saúde e outra sobre assuntos econômicos. Entre as sete classes indicadas pela CHD, a Classe 1 representa o tema economia e as Classes 2, 3, 5 e 6 representam temas em saúde. Depois de um século e meio de história, a aposentadoria continua sendo estudada principalmente a partir dos dois aspectos que ensejaram seu surgimento: o impacto do envelhecimento na saúde e a adequação das condições econômicas.

A disponibilidade mínima de saúde e dinheiro parece ser condição necessária a uma boa aposentadoria, mas não suficiente (Barbosa et al., 2016), ensejando pesquisas sobre outros temas relevantes para uma boa vida nesse estágio. Por exemplo, pouco tem sido feito para preparar os trabalhadores para essa transição de vida, embora esta demanda seja antiga (Lawton, 1941) e as evidências mostrem que intervenções preventivas podem ser efetivas 
(Leandro-França et al., 2016). Da mesma forma, fatores como lazer e suporte social, entre outros, podem aumentar a qualidade da vida na aposentadoria (Barbosa et al., 2016) e, portanto, representam campos de pesquisa potencialmente promissores.

Este estudo contribui para a pesquisa sobre aposentadoria ao retratar a organização do conhecimento na área, o que pode facilitar seu uso em situações aplicadas e informar os pesquisadores da área no planejamento de novos estudos. A análise desse panorama pode informar uma agenda de pesquisa sob medida para o campo da aposentadoria. A pesquisa sobre políticas públicas pode favorecer a integração entre os estudos em saúde e economia, otimizando a aplicação do conhecimento de cada área em favor do atendimento de demandas sociais. Com o destaque crescente do papel da aposentadoria na sociedade, dispor de um mapa sobre o conhecimento disponível na área pode nos ajudar a escolher e manter uma estratégia de desenvolvimento científico adequada.

\section{Referências}

Barbosa, L. M., Monteiro, B., \& Murta, S. G. (2016). Retirement Adjustment Predictors-A Systematic Review. Work, Aging and Retirement, 2(2), waw008. http://doi.org/10.1093/workar/waw008

Castro, F. G., Barrera Jr., M., \& Steiker, L. K. H. (2010). Issues and challenges in the design of culturally adapted evidence-based interventions. Annual Review of Clinical Psychology, 6, 213-39.

Darkwa, O. K., \& Mazibuko, F. N. M. (2002). Population aging and its impact on elderly welfare in Africa. International Journal of Aging \& Human Development, 54(2), 10723. http://doi.org/10.2190/XTQG-6DXD-9XWE-9X85

HelpAge (2013). Global AgeWatch Index 2013: Insight report. London: HelpAge International.

Lawton, G. (1941). After sixty-five? Mental Hygiene, 25, 414-419. 
Leandro-França, C., Giardini Murta, S., Hershey, D. A., \& Barbosa Martins, L. (2016). Evaluation of retirement planning programs: A qualitative analysis of methodologies and efficacy. Educational Gerontology, 1-16. doi: 10.1080/03601277.2016.1156380

Smallman, M. (2015). What has been the impact of public dialogue in science and technology on UK policymaking? (Tese de doutorado). Retirado de http://discovery.ucl.ac.uk/1473234/

United Nations Educational Scientific and Cultural Organization. (2013). World social science report 2013, Changing Global Environments. Paris. doi: 10.1787/9789264203419-en

United Nations. (2013). World Population Ageing 2013. New York. Retirado de http://bit.ly/1ONQFUA

Thane, P. (2006). The history of retirement. In G. L. Clark, A. H. Munnell, \& J. M. Orszag (Eds.), The Oxford Handbook of Pensions and Retirement Income (p. 33-51). Oxford University Press.

Tuesta, D. (2011). A review of the pension systems in Latin America. BBVA Research, $(11 / 15)$

World Health Organization. (2015). World Health Statistics 2015. Luxembourg. 


\section{ESTUDO 2}

Retirement Adjustment Predictors - A Systematic Review*

* Manuscrito publicado: Barbosa, L. M., Monteiro, B., \& Murta, S. G. (2016). Retirement Adjustment Predictors: A Systematic Review. Work, Aging and Retirement, 2(2). Publicação online. doi: waw008. http://doi.org/10.1093/workar/waw008 


\begin{abstract}
Human beings are living longer than ever. Amongst other consequences, this demographic trend increased retirement duration, what makes important to understand what factors contribute to a better life in retirement. In order to explore these factors and add to previous investigations, this study aimed to perform a systematic literature review concerning adjustment to retirement. For that, a total of 11 descriptors were surveyed in seven electronic databases seeking empirical studies addressing retirees, published between 1995 and 2014, and written either in English, Portuguese, or Spanish. A total of 3,255 records were identified, and resulted in a final sample of 115 papers after applying inclusion and exclusion criteria. The adjustment predictors were classified into 26 categories. Factors with larger empirical evidence on the benefits to adjustment are: physical health, finances, psychological health and personality-related attributes, leisure, voluntary retirement, and social integration. It is expected that these results allow comparing different predictors, fostering research on scarcely studied but promising predictors, and informing the development of retirement interventions.
\end{abstract}

Key words: retirement, retirement satisfaction, retirement adjustment.

Human life is being rapidly and continuously extended. During $99 \%$ of humankind's history, life expectancy was below 25 years (Hayflick, 2007). In 1950, 8\% of people were 60 years old or older; in 2013 this proportion was $12 \%$ and is expected to reach $21 \%$ in 2050 (United Nations; UN, 2013). One of the consequences of population aging is the increased number of years lived after retirement. In 1935, for instance, when social security was implemented in the United States of America, life expectancy was 60 years (National Vital Statistics System, 2011), but the minimum age to retire was 65 years (Costa, 1998). Today, an American can retire at the age of 67 years old but his/her life expectancy is 85 years 
(National Center for Health Statistics, 2014). And this is a general trend: in 2060, it is expected that people in European Union countries will retire at the age of 68 years while the average life expectancy will be 90 years (European Comission, 2015). Retirement is no longer an exception, but rather represents a substantial share of one's life cycle, what makes important to understand better what factors contribute to improve life in this stage.

Retirement is a phenomenon with different meanings across different contexts. The Organization for Economic Cooperation and Development (OECD) considers someone to be retired when, after the age of 40 years old, the individual remains out of the labor force for at least five years - what usually happens around 63 or 64 years old on average among its country members (OECD, 2013). The scientific literature provides retirement definitions based on at least eight different criteria (Denton \& Spencer, 2009): absence from the work force; reduced workload and/or remuneration; workload and/or remuneration below a certain minimum; receiving a retirement payout; no longer linked to a main employer; late career or job change; self-reported retirement; or some combination of these criteria. From a psychological perspective, retirement refers to leaving the workforce and the resulting psychological and behavioral distancing from work (Wang \& Shi, 2014).

Many theoretical models have been used to explain the psychological experiences related to retirement. Wang, Henkens, and van Solinge (2011) review five of them. Role theory proposes that retirement is a role transition that leads to weakening some roles (e. g., worker) and strengthening others (e. g. wife or husband). Continuity theory (Atchley, 1999) proposes that, despite work changes, identity and self-concept are partially preserved and it favors the transition. Stage theory (Atchley, 1976) describes this as a gradual transition that involves different forms of bridge employment (Beehr \& Bennett, 2015) until reaching full retirement. Life course (Settersten, 2003) and resource (Hobfoll, 2002) perspectives point 
that personal context (social and historical) and personal choices interact to influence this transition.

After reviewing these theories, Wang et al. (2011) develop the contextual element and propose a resource-based dynamic perspective. It posts that adjustment to retirement is a process involving individual resources and changes in these resources, such as physical, cognitive, motivational, emotional, financial, and social ones. As so, adjustment level is a function of resources availability: increasing resources leads to higher adjustment, and decreasing resources leads to lower adjustment. Considering the theoretical and empirical developments reached by other dynamic (Hesketh, Griffin, Dawis, \& Bayl-Smith, 2015) and contextualistic approaches (e. g., Vilardaga, Hayes, Levin, \& Muto, 2009; Wilson \& Gowdy, 2013; Wilson, Hayes, Biglan, \& Embry, 2014), resourced-based dynamic perspective may be a promising model for understanding and influencing retirees lives.

Amongst other aspects of this life stage, adjustment to retirement draws great attention from researchers. Besides developing this resource-based dynamic perspective as a broader theoretical framework, Wang et al. (2011) also propose a retirement adjustment definition compatible with that framework. According to them, retirement adjustment is the longitudinal process through which resources availability influence how retirees feel comfortable with retirement. By integrating their model and their definition, the authors highlight the central role some resources, or predictors, play in living a good life at retirement years.

Adjustment to retirement predictors have been extensively investigated. Since 2010, at least five reviews addressing the determinants of adjustment to life during retirement were published. The paper by Wang and Shultz (2010) synthetized two decades of scientific publications, organizing 22 predictors into four categories: individual (e. g., health); work and organizational (e. g., attachment to career); family (e. g., spouse's occupation); and 
socioeconomic (e. g., social security). Other conditions, such as gradual retirement and control over retirement decision, were presented as stages of the retirement process.

The review conducted by Wang, Henkens, and van Solinge (2011) found 25 variables that predict retirement adjustment. These predictors were organized into five categories: individual (e. g., mental health); pre-retirement work (e. g., unemployment); family (e. g., number of children); retirement transition (e. g., reasons for retirement); and post-retirement factors (e. g., leisure). The review conducted by Wang and Hesketh (2012) presented 34 predictors of wellbeing during retirement. They were classified into the same categories described by Wang et al. (2011) and also in accordance with one of the three types of wellbeing they impact. Financial well-being is influenced by factors such as physical health and financial planning; physical well-being is influenced by factors such as healthy habits and gradual retirement; and psychological well-being is influenced by factors such as finances and quality of marital relationships.

Also in 2012, van Solinge summarized retirement adjustment literature and organized predictors in four categories: individual attributes (e. g., age), resources (e. g., health), situational characteristics (pre-retirement job characteristics, job commitment, and retirement circumstances such as work stress and involuntary retirement); and psychological attributes (personality and psychological dispositions such as motivation and perceived control). Finally, the review conducted by França \& Murta (2014) described factors that post risk or protection to one's adaptation to retirement. The 20 predictors found were classified into three levels: personal, such as health problems (risk) and marital relationship (protection); psychosocial factors, such as depression (risk) and volunteer work (protection); and organizational, such as unemployment (risk) and control over the decision to retire (protection). 
These reviews present convergent results. Nonetheless, they also present three major issues: (1) grouping different outcomes without describing grouping criteria, (2) not showing how much evidence support each predictor, and (3) not describing articles' search strategies. Regarding the first issue, variables such as quality of life, depression and attitude toward retirement are labeled under retirement adjustment (Wang, Henkens, \& van Solinge, 2011). Marriage quality and positive and negative influences during retirement are labeled as wellbeing (Wang \& Hesketh, 2012). And well-being, retirement planning, and emotions and feelings toward retirement are labeled as retirement adaptation (França \& Murta, 2014). Gathering so diverse variables builds outcomes that are too generic, and less useful when developing theoretical models or intervention strategies. Regarding the second issue, predictors are not distinguished according to their empirical evidence. For example, there is consensus on health and marital relationship being predictors, but it is not clear how influent or reliable each one is. And regarding the third issue, it is not clear what search strategies were used to select original publications, nor the resulting potential selection biases.

Considering these issues, this study aims to perform a systematic review on retirement adjustment predictors. We believe it may complement existing reviews by providing three main contributions. First, it will describe more narrowly defined outcomes. Second, it will provide empirical evidence that allows comparing predictors. Third, it may provide a more comprehensive view on the resources that influence retirement adjustment, as previously recommended (Wang, Henkens, \& van Solinge, 2011).

\section{Method}

Retirement adjustment is a construct clearly defined. According to van Solinge and Henkens (2008), it is the process of getting used to life changes resulting from retirement. It relates mainly to expectancies over personal contacts, social status and control over retirement decision. However, the literature on retirement adjustment predictors refers to 
studies with conceptually diverse outcomes. In order to overcome it, we propose to investigate retirement adjustment as a latent construct measured through only five variables all of them regarding subjective life evaluations frequently studied in this field. It would allow this review to reach a large amount of studies and, at the same time, define a more precise outcome.

These five variables are: retirement adjustment (van Solinge \& Henkens, 2008); life satisfaction and well-being (Snyder \& Lopez, 2009), as cognitive and affective subjective evaluations; quality of life (Sim, Bartlam, \& Bernard, 2011), referring to different personal domains, including control, autonomy, pleasure and self-realization; and retirement satisfaction (van Solinge and Henkens, 2008), defined as contentment with life during retirement. Labeling this group of constructs as an outcome category, retirement adjustment, will allow us to describe a wide and coherent general and subjective evaluation of life after leaving work.

\section{Search Strategy}

A systematic electronic search of studies published between 1990 and October 2014 was conducted. The seven electronic databases included: PsycInfo and PsycArticles, Pubmed, ISI Web of Knowledge, IngentaConnect, Elsevier and Emerald. Eleven descriptors were used: retirement $\mathrm{OR}$ retiring $\mathrm{OR}$ retire (related to retirement) AND scale OR measure $\mathrm{OR}$ instrument OR questionnaire, (related to data collection methods) AND satisfaction OR adjustment OR well-being OR quality of life (related to criterion of interest).

\section{Criteria for Selecting Studies}

Empirical studies published in Portuguese, English or Spanish were included. Only data based on retirees were considered, including both cross sectional and longitudinal designs. Studies based on samples composed of athletes, groups that usually retire early to enter the regular job market, and studies assessing types of satisfaction other than satisfaction 
with life or with retirement were excluded. In order to conduct a broad review, the studies were not excluded or classified based on their methodological rigor.

\section{Extraction of Data}

The main characteristics of reviewed studies were extracted including keywords, country of origin, data source (primary or secondary), technique used to collect data, design, number of data collection procedures, sample size, method of data analysis, context of sample, sample characteristics, proportion of women, average age, standard deviation and range of age, duration of retirement, predictor variables, criterion variables, and results. Then predictor variables were ranked according to the amount of evidence showing their impact (positive, non-significant, and negative) on the criterion variables, as presented in Table 2.

\section{Results}

A total of 3,255 records were identified (see Figure 1). Papers identified in more than one database $(\mathrm{n}=342)$ were excluded, remaining 2,913 studies. Title, abstract, and method were reviewed to identify studies that met the eligibility criteria. A total of 2,825 studies were excluded mainly because they investigated samples or outcome variables out of the reach of this study, or because retirees' data was indistinguishable from other samples' data. In addition, cited references of the captured studies were also searched. Surprisingly, a large number of studies that fit the criteria, $n=27$, were found and included in the review, suggesting that checking references may be an important stage in future search strategies. In the end, 115 papers matched the selection criteria and were included. 


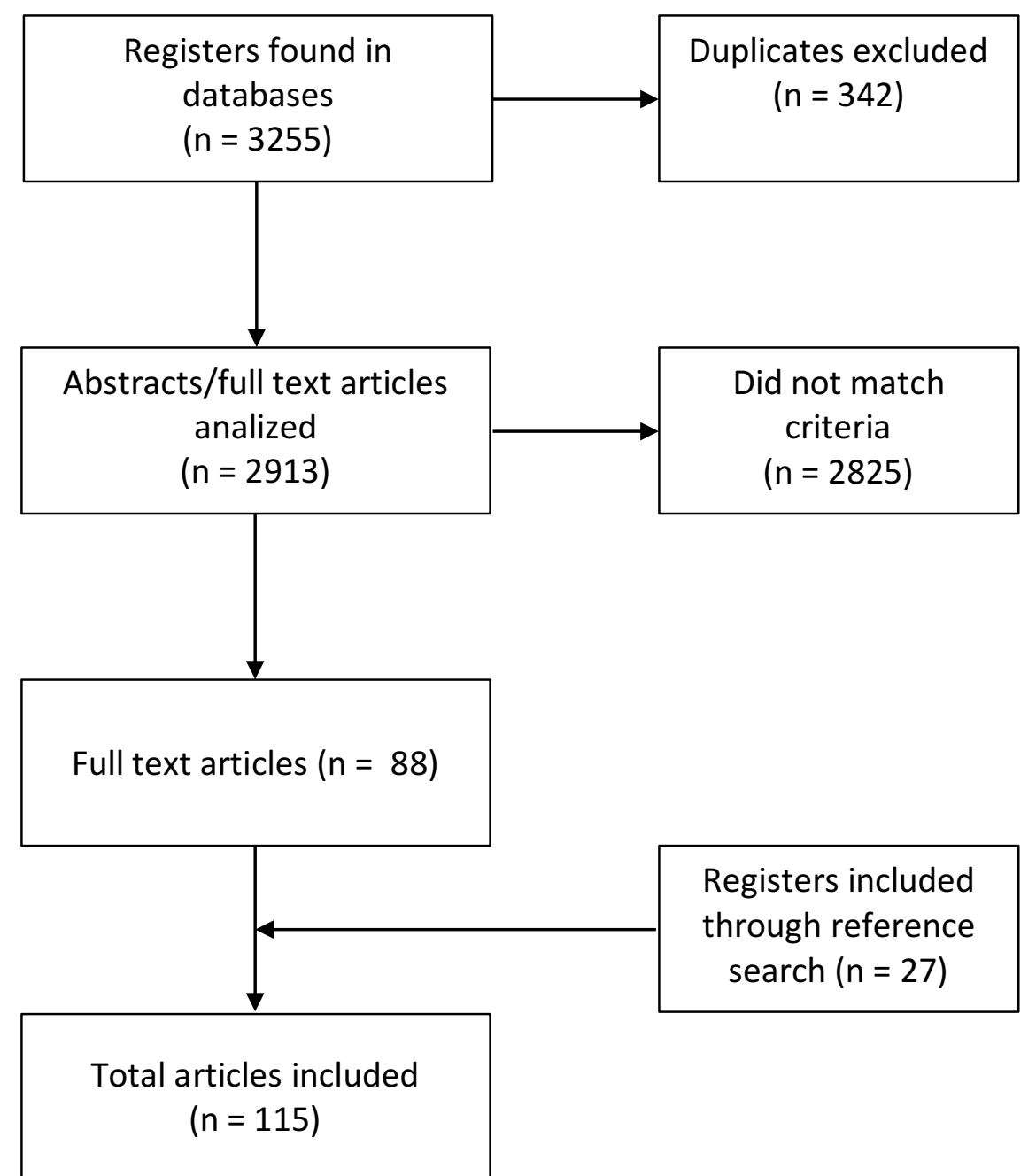

Figure 1. Flowchart of study selection strategy.

Some of the articles characteristics are included in Table 1. Among the 115 studies found, 107 were published in English, six in Spanish and two in Portuguese. The number of papers published increased over the period of 20 years under study: an average of 3.4 studies were published yearly between 1995 and 2003; this number rose to 7.4 between 2004 and 2008; and it reached 9.3 between 2009 and 2014. The studies were conducted in 31 countries on all the continents except Africa. The most frequent countries were the United States of America $(n=36)$, followed by Spain $(n=9)$, France $(n=9)$, United Kingdom $(n=9)$, Australia $(\mathrm{n}=8)$, Canada $(\mathrm{n}=8)$ and Netherlands $(\mathrm{n}=7)$. All articles reviewed are included in a reference list on Appendix. 
Table 1. Characteristics of the reviewed studies.

\begin{tabular}{|c|c|c|c|c|c|c|}
\hline Reference & Country & Design & $\mathbf{N}$ & Age & Results & \\
\hline & & & & & Predictor variables & $\begin{array}{l}\text { Criterion } \\
\text { variables }\end{array}$ \\
\hline Alpass $^{1}$ & $\begin{array}{l}\text { New } \\
\text { Zealand }\end{array}$ & $\mathrm{CS}$ & 6662 & $55+$ & Voluntary job status + , social integration + , mental health + & A \\
\hline Asebedo $^{2}$ & USA & $\mathrm{L}$ & 5146 & $50+$ & $\begin{array}{l}\text { Optimism }+ \text {, family support }+ \text {, purpose in life }+ \text {, perceived mastery }+ \text {, } \\
\text { age }+ \text {, income }+ \text {, health status }+ \text {, difficulties with daily activities }-\end{array}$ & $\mathrm{RS}$ \\
\hline Austrom $^{3}$ & USA & $\mathrm{CS}$ & 678 & 75 & $\begin{array}{l}\text { Health }+ \text {, optimism }+ \text {, financial security }+ \text {, hobbies }+ \text {, being married } \\
+ \text {, age }- \text {, years in retirement }+ \text {, relationship with spouse }+ \text {, sexual } \\
\text { relationship }+\end{array}$ & LS \\
\hline Ballew $^{4}$ & USA & $\mathrm{L}$ & 164 & 83.9 & Spiritual activities + , spiritual experiences + , health + & LS \\
\hline Barret $^{5}$ & Australia & $\mathrm{L}$ & 1344 & 66.8 & $\begin{array}{l}\text { Retired due job loss -, retired due own health }- \text {, retired due partner } \\
\text { health -, retired for over } 5 \text { years }+ \text {, living in a rural area }+ \text {, partnered } \\
+, \text { retired due partner retirement }- \text {, income lesser then expected }- \text {, } \\
\text { income greater than expected }+ \text {, health improvement after retirement } \\
+ \text {, health worsening after retirement - }\end{array}$ & WB \\
\hline Becchetti $^{6}$ & Germany & $\mathrm{L}$ & 156232 & - & $\begin{array}{l}\text { Household income }+ \text {, house owner }+ \text {, education }+ \text {, unemployed }- \text {, job } \\
\text { loss }+ \text {, full time job }+ \text {, part time job }+ \text {, vocational training }+ \text {, military } \\
\text { service }+ \text {, marriage }+ \text {, left being married -, children in household }+ \text {, } \\
\text { hospital stay -, occupational disability - }\end{array}$ & LS \\
\hline Bender $^{7}$ & USA & $\mathrm{CS}$ & 6246 & - & $\begin{array}{l}\text { Male -, being married }+ \text {, age }+ \text {, lower income }- \text {, forced to retire -, } \\
\text { poor health -, working }+ \text {, spouse working -, health insurance }+\end{array}$ & $\mathrm{RS}$ \\
\hline Benyamini $^{8}$ & USA & $\mathrm{L}$ & 850 & 72.2 & $\begin{array}{l}\text { Self-rated health }+ \text {, self-rated oral health }+ \text {, male }+ \text {, functional } \\
\text { disability - }\end{array}$ & LS \\
\hline Berninger $^{9}$ & USA & CS & 4678 & - & Cough syndrome conditions - & QoL \\
\hline Bonsang $^{10}$ & Germany & $\mathrm{L}$ & 4541 & 59.5 & $\begin{array}{l}\text { Involuntary retirement }- \text {, age }- \text {, living in couple }+ \text {, doctor visits }- \text {, } \\
\text { legal degree of disability }- \text {, hospital stay }- \text {, satisfaction with health }+ \text {, } \\
\text { satisfaction with income }+ \text {, satisfaction with free time }+\end{array}$ & LS \\
\hline Brajković $^{11}$ & Croatia & $\mathrm{CS}$ & 300 & 75.5 & $\begin{array}{l}\text { Having children }+ \text {, mental health }+ \text {, loneliness }- \text {, active sense of } \\
\text { humor }+\end{array}$ & LS \\
\hline Bretherton $^{12}$ & Australia & $\mathrm{CS}$ & 212 & 80.4 & Optimism,+ perceived stress,+ perceived control + & QoL \\
\hline Butkovic ${ }^{13}$ & Croatia & $\mathrm{CS}$ & 134 & 77.2 & Extraversion + , emotional stability + , self-esteem -, loneliness - & WB \\
\hline $\begin{array}{l}\text { Cadenas- } \\
\text { Salazar }^{14}\end{array}$ & Spain & $\mathrm{CS}$ & 29 & - & Functional social support + & LS \\
\hline Calasanti $^{15}$ & USA & $\mathrm{L}$ & 1031 & 68.8 & Male -, financial satisfaction + , health + , being married + education + & LS \\
\hline Calvo $^{16}$ & USA & $\mathrm{L}$ & 2389 & 62.6 & $\begin{array}{l}\text { Retirement wanted }+ \text {, spouse death -, improved health }+ \text {, benefit } \\
\text { pension }+\end{array}$ & WB \\
\hline
\end{tabular}


Bridge employment + , quality of bridge employment + , age - , health problems - , optimism + , good health + , marital quality + , income +

$\begin{array}{lllll}\text { Cantisano }^{17} & \text { Spain } & \text { CS } & 650 & 63\end{array}$

Bridge employment + , age -, health problems -, optimism + , good health + , bad mental health -

\begin{tabular}{|c|c|c|c|c|c|c|}
\hline Chiang $^{18}$ & $\begin{array}{l}\text { China } \\
\text { (Taiwan) }\end{array}$ & $\mathrm{CS}$ & 268 & 64.7 & Subjective health + , family relationships + & WB \\
\hline Choi $^{19}$ & USA & $\mathrm{L}$ & 3259 & 73.4 & $\begin{array}{l}\text { Age -, number of daily activities with difficulty -, widowed -, } \\
\text { divorced/separated/never married -, income }+, \text { worries about money - }\end{array}$ & RS \\
\hline Clarke $^{20}$ & USA & $\mathrm{L}$ & 1684 & 53.8 & $\begin{array}{l}\text { Expectations fulfilled }+ \text {, age }+ \text {, high school education-, number of } \\
\text { health problems - }\end{array}$ & LS \\
\hline Coursolle $^{21}$ & USA & $\mathrm{L}$ & 2855 & 64.5 & $\begin{array}{l}\text { Family-work interferences }+, \log \text { net worth }+ \text {, spousal health declined } \\
-, \text { respondent health declined }-, \text { education }+ \text {, well-being }+ \text {, feels very } \\
\text { close to spouse }+ \text {, worked over } 50 \text { hours per week }+ \text {, self-employed } \\
+, \log \text { hourly wage }+, \text { female }+\end{array}$ & WB \\
\hline \multirow{2}{*}{ De Vaus ${ }^{22}$} & \multirow{2}{*}{ Australia } & \multirow{2}{*}{$\mathrm{L}$} & \multirow{2}{*}{358} & \multirow{2}{*}{58} & Abrupt retirement + , control over retirement + & A \\
\hline & & & & & Control over retirement + & LS \\
\hline Dingemans $^{23}$ & Netherlands & $\mathrm{L}$ & 1615 & 64 & $\begin{array}{l}\text { Involuntary retirement -, bridge employment }+ \text {, living with a partner } \\
+ \text {, health problems -, self-efficacy }+ \text {, female - }\end{array}$ & LS \\
\hline Dingemans $^{24}$ & Netherlands & $\mathrm{L}$ & 1248 & 61.5 & $\begin{array}{l}\text { Life satisfaction }+ \text {, health declined }- \text {, perceived pension shortfall -, } \\
\text { living with a partner }+ \text {, high occupational level }+ \text {, involuntary } \\
\text { retirement }- \text {, bridge employment due financial needs -, bridge } \\
\text { employment for enjoyment }+\end{array}$ & LS \\
\hline Donaldson $^{25}$ & Australia & $\mathrm{CS}$ & 570 & 64.9 & $\begin{array}{l}\text { psychological health }+ \text {, physical health }+ \text {, personal sense of mastery } \\
+ \text {, good conditions when retiring }+\end{array}$ & A \\
\hline Dorfman $^{26}$ & USA & $\mathrm{CS}$ & 451 & 72 & Health conditions - & RS \\
\hline Edén $^{27}$ & Sweden & $\mathrm{CS}$ & 376 & - & $\begin{array}{l}\text { Disability pension -, age -, immigrants -, early retirement due } \\
\text { disability pension -, male - }\end{array}$ & QoL \\
\hline Elder $^{28}$ & USA & $\mathrm{CS}$ & 1781 & - & $\begin{array}{l}\text { Retirement thinking }+ \text {, attending retirement planning meetings }+ \text {, } \\
\text { household income }+ \text {, married }+ \text {, retirement due health -, forced } \\
\text { retirement - }\end{array}$ & $\mathrm{RS}$ \\
\hline Elgarresta $^{29}$ & Spain & $\mathrm{CS}$ & 119 & 66.5 & Anxiety -, depression -, income + , physical status + & LS \\
\hline Farquhar $^{30}$ & Canada & $\mathrm{L}$ & 289 & 58.9 & Female + , regret management + & $\mathrm{RS}$ \\
\hline Fernández ${ }^{31}$ & Spain & $\mathrm{CS}$ & 638 & 61.3 & Involuntary retirement - & A \\
\hline Fernánde $z^{32}$ & Spain & $\mathrm{CS}$ & 638 & 61.2 & Professional category + , age of early retirement + & $\mathrm{RS}$ \\
\hline Fouquereau $^{33}$ & France & $\mathrm{CS}$ & 555 & - & Social activities + , retirement due to circumstances -, health and & LS \\
\hline
\end{tabular}




\begin{tabular}{|c|c|c|c|c|c|c|}
\hline & & & & & $\begin{array}{l}\text { resources }+ \text {, anticipated satisfaction }+ \text {, freedom and control }+ \text {, } \\
\text { marriage and home }+ \text {, reduced stress/responsibilities }+ \text {, own interests } \\
+, \text { satisfaction with job before retirement }+ \text {, pressure from employer - } \\
\text {, not being alone }+\end{array}$ & \\
\hline Fouquereau $^{34}$ & Multiple & $\mathrm{CS}$ & 1686 & - & $\begin{array}{l}\text { Health and resources satisfaction }+ \text {, marriage and family satisfaction } \\
+, \text { freedom and control satisfaction }+ \text {, anticipated satisfaction }-\end{array}$ & $\mathrm{RS}$ \\
\hline Funkhouser $^{35}$ & Switzerland & $\mathrm{L}$ & 102 & 62.7 & Dream-reality boundary thinness - & LS \\
\hline Gall $^{36}$ & Canada & $\mathrm{L}$ & 109 & 68.9 & Expected retirement satisfaction + & QoL \\
\hline $\mathrm{Gall}^{37}$ & Canada & $\mathrm{L}$ & 117 & 68.9 & $\begin{array}{l}\text { Activity }+ \text {, financial }+ \text {, projected income }+ \text {, health }+ \text {, illness }- \text {, } \\
\text { interpersonal }+ \text {, retirement type -, external locus of control - }\end{array}$ & A \\
\hline Guinn $^{38}$ & USA & $\mathrm{CS}$ & 405 & 71.4 & $\begin{array}{l}\text { Desire for leisure challenge }+ \text {, leisure commitment }- \text {, leisure } \\
\text { competence }+\end{array}$ & LS \\
\hline Hardy $^{39}$ & USA & $\mathrm{CS}$ & 1148 & - & $\begin{array}{l}\text { Retirement due health reasons -, retirement due pull reasons }+ \text {, } \\
\text { unpleasant job conditions -, risk of being laid off before exit -, } \\
\text { household income }+ \text {, special plan -, age }+ \text {, late timing of the } \\
\text { retirement decision - }\end{array}$ & RS \\
\hline Hershey $^{40}$ & Netherlands & $\mathrm{L}$ & 1388 & 60.1 & $\begin{array}{l}\text { Education }+ \text {, job status }+ \text {, self-rated health }+ \text {, wealth }+ \text {, positive } \\
\text { health change }+ \text {, negative health change }- \text {, divorced }- \text {, widowed }- \text {, } \\
\text { voluntary retirement }+ \text {, involuntary retirement due health -, } \\
\text { involuntary retirement due organizational reasons - }\end{array}$ & LS \\
\hline Hervé $^{41}$ & France & $\mathrm{CS}$ & 579 & 72.2 & Adaptation + & LS \\
\hline Hillman ${ }^{42}$ & Scotland & $\mathrm{L}$ & 75 & - & Participation in leisure activities + & QoL \\
\hline $\mathrm{Kim}^{43}$ & Multiple & $\mathrm{CS}$ & 13210 & 63 & Self-rated health + , physical functioning + , depression - & QoL \\
\hline $\mathrm{Kim}^{44}$ & USA & $\mathrm{L}$ & 458 & 62.4 & $\begin{array}{l}\text { Pre-retirement well-being }+ \text {, income adequacy }+ \text {, subjective health }+ \text {, } \\
\text { personal control }+\end{array}$ & WB \\
\hline \multirow{2}{*}{$\mathrm{Kim}^{45}$} & \multirow{2}{*}{ USA } & \multirow{2}{*}{$\mathrm{CS}$} & \multirow{2}{*}{371} & \multirow{2}{*}{65.2} & $\begin{array}{l}\text { Bridge employment }+ \text {, leisure activity }+ \text {, health }+ \text {, monthly salary at } \\
\text { retirement }+ \text {, pre-retirement counseling }+ \text {, working spouse - }\end{array}$ & $\mathrm{RS}$ \\
\hline & & & & & $\begin{array}{l}\text { Bridge employment }+ \text {, volunteer work }+ \text {, leisure activity }+ \text {, health }+ \text {, } \\
\text { monthly pension benefit }+ \text {, working spouse }- \text {, dependent children - }\end{array}$ & LS \\
\hline Kirby ${ }^{46}$ & England & CS & 233 & 80 & Degree of frailty -, spirituality + , marital status - & WB \\
\hline Knesebec $^{47}$ & Multiple & $\mathrm{CS}$ & 15080 & $65+$ & Education + , income + , car ownership + , net worth + & QoL \\
\hline Kubicek $^{48}$ & USA & $\mathrm{L}$ & 1728 & 65 & $\begin{array}{l}\text { Preretirement well-being }+ \text {, female }+ \text {, closeness to spouse }+ \text {, hourly } \\
\text { wage }+ \text {, flexible goal adjustment }+ \text {, tenacious goal pursuit }+ \text {, poor } \\
\text { health -, job dissatisfaction - }\end{array}$ & WB \\
\hline $\mathrm{Kuo}^{49}$ & Singapore & $\mathrm{CS}$ & 54 & 64 & Participation on social activities + & WB \\
\hline
\end{tabular}




\begin{tabular}{|c|c|c|c|c|c|c|}
\hline Latif $^{50}$ & Canada & $\mathrm{L}$ & 22040 & - & Marital status,+ income,+ health status + & WB \\
\hline $\mathrm{Lee}^{51}$ & $\begin{array}{l}\text { China } \\
\text { (Hong } \\
\text { Kong) }\end{array}$ & $\mathrm{CS}$ & 1078 & - & $\begin{array}{l}\text { Stocks/funds/bonds for retirement }+ \text {, regular medical checkup }+ \text {, } \\
\text { discussed with family members about retirement }- \text {, enough money for } \\
\text { retirement }+ \text {, depend on oneself to achieve satisfaction }+\end{array}$ & $\mathrm{RS}$ \\
\hline $\mathrm{Lee}^{52}$ & $\begin{array}{l}\text { China } \\
\text { (Taiwan) }\end{array}$ & $\mathrm{CS}$ & 352 & - & Exercise frequency + , exercise intensity - & WB \\
\hline \multirow[b]{2}{*}{ Leung $^{53}$} & \multirow[b]{2}{*}{ Australia } & \multirow[b]{2}{*}{$\mathrm{L}$} & \multirow[b]{2}{*}{267} & \multirow[b]{2}{*}{66.2} & Resources + , years retired + & A \\
\hline & & & & & $\begin{array}{l}\text { Resources }+ \text {, gender }- \text {, age }+ \text {, years working as volunteer or employee } \\
\text { after retirement }+ \text {, relationship status }+\end{array}$ & $\mathrm{RS}$ \\
\hline Litwin ${ }^{54}$ & Israel & $\mathrm{CS}$ & 1334 & $60+$ & Quality of social relationships + , income - & WB \\
\hline Löckenhoff ${ }^{55}$ & USA & $\mathrm{CS}$ & 144 & 63.1 & $\begin{array}{l}\text { Neuroticism -, extraversion }+ \text {, education }+ \text {, physical health }+ \text {, } \\
\text { voluntariness }+\end{array}$ & $\mathrm{RS}$ \\
\hline Lowis $^{56}$ & UK & $\mathrm{CS}$ & 133 & 72 & Internal locus of control + , self-rated health + & QoL \\
\hline \multirow{2}{*}{ Lowis $^{57}$} & \multirow{2}{*}{ UK } & \multirow{2}{*}{$\mathrm{CS}$} & \multirow{2}{*}{121} & \multirow{2}{*}{75.8} & $\begin{array}{l}\text { Retirement adjustment }+ \text {, self-rated health }+ \text {, retirement stress -, } \\
\text { engagement in voluntary work }+\end{array}$ & LS \\
\hline & & & & & Ideal job level + , health improvement + & A \\
\hline Marshall $^{58}$ & Canada & $\mathrm{CS}$ & 2146 & 60.7 & $\begin{array}{l}\text { Unemployment periods -, involuntary job status -, household income } \\
+, \text { marital status + number of dependent children - }\end{array}$ & LS \\
\hline Maule $^{59}$ & England & $\mathrm{CS}$ & 608 & 61 & $\begin{array}{l}\text { Satisfaction with employment status }+ \text {, retirement due health reasons } \\
-, \text { adequacy financial settlement }+ \text {, amount of advice on retirement }+\end{array}$ & QoL \\
\hline \multirow{2}{*}{ McMunn $^{60}$} & \multirow{2}{*}{ England } & \multirow{2}{*}{$\mathrm{CS}$} & \multirow{2}{*}{5384} & \multirow{2}{*}{-} & Paid/voluntary work + , appreciation + & LS \\
\hline & & & & & Paid/voluntary work + , appreciation + & QoL \\
\hline Michinov $^{61}$ & France & $\mathrm{CS}$ & 154 & 59.2 & Affective identity + & RS \\
\hline $\operatorname{Mimrot}^{62}$ & India & $\mathrm{CS}$ & 400 & $60+$ & Male - & A \\
\hline Miyakita $^{63}$ & Japan & $\mathrm{CS}$ & 210 & 60.6 & $\begin{array}{l}\text { Health practice }+ \text {, social support network }+ \text {, self-rated health }+ \text {, } \\
\text { handicap score - }\end{array}$ & LS \\
\hline Nguyen $^{64}$ & Canada & CS & 190 & 71,7 & $\begin{array}{l}\text { Fear -, current activity }+ \text {, perceived social support }+ \text {, postretirement } \\
\text { work }+ \text {, retirement due circumstances - }\end{array}$ & LS \\
\hline
\end{tabular}




\begin{tabular}{|c|c|c|c|c|c|c|}
\hline & & & & & Fear -, current activity + , perceived social support + & RS \\
\hline Nimrod $^{65}$ & Israel & $\mathrm{CS}$ & 383 & 64.3 & $\begin{array}{l}\text { Cultural activities }+ \text {, health }+ \text {, outdoor activities }+ \text {, spirituality and } \\
\text { enrichment }+ \text {, marital status }+ \text {, essentiality }+ \text {, spouse illness }- \text {, income } \\
+ \text {, popular culture }+ \text {, following generation }+ \text {, choose to retire }+ \text {, } \\
\text { hobbies/listening to music }+\end{array}$ & LS \\
\hline Nimrod $^{66}$ & Israel & $\mathrm{CS}$ & 383 & 64.3 & $\begin{array}{l}\text { Use of free time }+ \text {, cultural activities }+ \text {, outdoor activities }+ \text {, health }+ \text {, } \\
\text { following generation care }+ \text {, family }+ \text {, income }+ \text {, popular culture }+ \text {, } \\
\text { spirituality and enrichment }+ \text {, reading newspapers }+ \text {, independent } \\
\text { home activity }+\end{array}$ & LS \\
\hline $\operatorname{Nimrod}^{67}$ & $\begin{array}{l}\text { Israel and } \\
\text { USA }\end{array}$ & $\mathrm{CS}$ & 813 & 65.3 & $\begin{array}{l}\text { Siblings }+ \text {, physical activity }+ \text {, education }+ \text {, subjective health }+ \text {, } \\
\text { marital status }+ \text {, years in retirement - }\end{array}$ & LS \\
\hline Nimrod $^{68}$ & USA & $\mathrm{L}$ & 430 & 66.2 & $\begin{array}{l}\text { Life satisfaction }+ \text {, socioeconomic status -, satisfaction with health -, } \\
\text { volunteering }+\end{array}$ & LS \\
\hline Noone $^{69}$ & USA & $\mathrm{L}$ & 1008 & 69 & $\begin{array}{l}\text { Preparing for retirement }+ \text {, income }+ \text {, preretirement physical }+ \text { and } \\
\text { psychological health }+ \text {, reasons for retirement }+\end{array}$ & $\mathrm{RS}$ \\
\hline Noone $^{70}$ & Australia & $\mathrm{CS}$ & 304 & 60.3 & $\begin{array}{l}\text { Retirement preparededness }+ \text {, age }+ \text {, years in retirement }+ \text {, income }+ \text {, } \\
\text { living standards }+ \text {, retirement optimism }+ \text {, social activity }+ \text {, physical } \\
\text { activity }+\end{array}$ & LS \\
\hline Nordenmark $^{71}$ & Sweden & $\mathrm{CS}$ & 1502 & - & $\begin{array}{l}\text { Involuntary retirement -, influence on the timing of retirement time }+ \text {, } \\
\text { lack of financial margin -, not having a close friend -, living alone -, } \\
\text { more years retired -, age }+ \text {, male }+\end{array}$ & WB \\
\hline $\begin{array}{l}\text { Nuttman- } \\
\text { Shwartz }\end{array}$ & Israel & $\mathrm{L}$ & 36 & 65.9 & References to work + & WB \\
\hline Oliveira $^{73}$ & Brazil & $\mathrm{CS}$ & 118 & 64.7 & $\begin{array}{l}\text { Retirement planning }+ \text {, transportation satisfaction }+ \text {, health } \\
\text { satisfaction }+ \text {, social relationships }+\end{array}$ & WB \\
\hline Pattani $^{74}$ & $\begin{array}{l}\text { England } \\
\text { and Wales }\end{array}$ & $\mathrm{L}$ & 986 & 51.8 & Retirement due ill health -, years in retirement + & QoL \\
\hline Pimenta $^{75}$ & Brazil & $\mathrm{CS}$ & 87 & 57.3 & Current work activity + & QoL \\
\hline Pizzola $^{76}$ & Canada & $\mathrm{CS}$ & 180 & 88 & Mealtime satisfaction + & QoL \\
\hline Platts $^{77}$ & France & $\mathrm{CS}$ & 10841 & - & $\begin{array}{l}\text { Physical occupational exposures of ergonomic strain -, physical } \\
\text { danger -, physical health }+ \text {, mental health }+\end{array}$ & QoL \\
\hline Platts $^{78}$ & France & $\mathrm{L}$ & 11293 & 61 & $\begin{array}{l}\text { Mental health }+ \text {, physical functioning }+ \text {, wealth }+ \text {, status }+ \text {, social } \\
\text { participation }+\end{array}$ & QoL \\
\hline Potocnik $^{79}$ & Multiple & $\mathrm{L}$ & 2813 & 68.9 & $\begin{array}{l}\text { Number of limited daily activities }- \text {, age }- \text {, marital status }+ \text {, financial } \\
\text { status }+ \text {, education }+ \text {, volunteering }+ \text {, providing help }+ \text {, going to } \\
\text { sports or social clubs }+\end{array}$ & QoL \\
\hline
\end{tabular}




\begin{tabular}{|c|c|c|c|c|c|c|}
\hline \multirow[t]{2}{*}{ Potocnik 80} & \multirow[t]{2}{*}{ Spain } & \multirow[t]{2}{*}{ CS } & \multirow[t]{2}{*}{213} & \multirow[t]{2}{*}{62.5} & $\begin{array}{l}\text { Group norms favorable to early retirement }+, \text { perceived ability to } \\
\text { continue working -, early retirement intentions }+ \text {; organizational } \\
\text { pressures toward retirement (among involuntary retirees) }+ \text {; } \\
\text { organizational pressures toward retirement (among voluntary ones) - }\end{array}$ & RS \\
\hline & & & & & Retirement satisfaction + & WB \\
\hline Price $^{81}$ & USA & $\mathrm{CS}$ & 330 & 64 & $\begin{array}{l}\text { Income }+ \text {, self-esteem }+ \text {, mastery }+ \text {, emotional support received last } \\
\text { year }+ \text {, ethnic minority }+\end{array}$ & $\mathrm{RS}$ \\
\hline Price $^{82}$ & USA & $\mathrm{CS}$ & 331 & 64 & Married + , remarried + , divorced/separated - & RS \\
\hline Quick $^{83}$ & USA & $\mathrm{L}$ & 458 & 63 & $\begin{array}{l}\text { Poor health -, income }+ \text {, unemployment gaps }+ \text {, psychological } \\
\text { demands }- \text {, retirement due family health }- \text {, financial incentives }+ \text {, } \\
\text { work was not appreciated }+ \text {, retired because job ended }+ \text {, retired late - } \\
\text {, retired later than expected - }\end{array}$ & $\mathrm{RS}$ \\
\hline \multirow{2}{*}{ Quine $^{84}$} & \multirow{2}{*}{ Australia } & \multirow{2}{*}{$\mathrm{L}$} & \multirow{2}{*}{601} & \multirow{2}{*}{60} & Choice + & LS \\
\hline & & & & & Choice + & A \\
\hline $\operatorname{Ramos}^{85}$ & Spain & $\mathrm{L}$ & 165 & 53 & Mood + & LS \\
\hline Reitzes $^{86}$ & USA & $\mathrm{L}$ & 376 & - & $\begin{array}{l}\text { Pre-retirement positive attitudes }+ \text {, self-steem }+ \text {, married }+ \text {, friend } \\
\text { identity meaning }+ \text {, poor health }- \text {, pension }+ \text {; being a parent }+ \text {, } \\
\text { occupation }+ \text {; retirement planning }+\end{array}$ & A \\
\hline Riquelme $^{87}$ & Spain & $\mathrm{CS}$ & 185 & - & $\begin{array}{l}\text { Relationship with younger people }+ \text {, relationship with same-age } \\
\text { people }- \text {, marital satisfaction }+ \text {, friend contact frequency }+ \text {, social } \\
\text { network extension }+ \text {, family value reported }+ \text {, social activity level }+ \text {, } \\
\text { emotional support sources }+\end{array}$ & WB \\
\hline Robinson $^{88}$ & USA & $\mathrm{CS}$ & 279 & 64.5 & Aspirational motivation + , agreeableness + , neuroticism - & LS \\
\hline Rosenkoetter $^{89}$ & USA & $\mathrm{CS}$ & 764 & - & Planning before retirement + & A \\
\hline Seligowski ${ }^{90}$ & USA & $\mathrm{CS}$ & 562 & 70 & Age + , marital status + , personal resources + , functional health + & $\mathrm{LS}$ \\
\hline Sener $^{91}$ & Turkey & $\mathrm{CS}$ & 231 & 65.7 & $\begin{array}{l}\text { Satisfaction from leisure activities }+ \text {, participation in leisure activities } \\
+ \text {, perceived health }+ \text {, leisure repertoire planning }+ \text {, income }+ \text {, } \\
\text { educational level }+\end{array}$ & LS \\
\hline \multirow{2}{*}{ Shultz ${ }^{92}$} & \multirow{2}{*}{ USA } & \multirow{2}{*}{ CS } & \multirow{2}{*}{992} & \multirow{2}{*}{60} & Voluntariness + & LS \\
\hline & & & & & Voluntariness + & RS \\
\hline $\operatorname{Sim}^{93}$ & UK & $\mathrm{CS}$ & 120 & 77.5 & Life satisfaction + , physical health + , mental health + & QoL \\
\hline Smith $^{94}$ & USA & $\mathrm{CS}$ & 241 & - & Wives influence in retirement decision (for man) + ; reported health + , & RS \\
\hline
\end{tabular}




\begin{tabular}{|c|c|c|c|c|c|c|}
\hline & & & & & $\begin{array}{l}\text { income adequacy }+ \text {, retiring due to an early retirement incentive } \\
\text { package }+ \text {, wife with modern gender ideology - }\end{array}$ & \\
\hline Spiegel $^{95}$ & USA & $\mathrm{L}$ & 672 & 45.3 & Pre-retirement planning + & RS \\
\hline Stephan $^{96}$ & France & $\mathrm{CS}$ & 235 & 67 & $\begin{array}{l}\text { Openness to subjective health }+ \text {, financial satisfaction }+ \text {, openness to } \\
\text { feelings }+ \text {, openness to ideas }+\end{array}$ & LS \\
\hline Stephan $^{97}$ & France & $\mathrm{CS}$ & 256 & 63.8 & Perceived health + , body satisfaction + & RS \\
\hline Stephan $^{98}$ & France & $\mathrm{CS}$ & 150 & 63.2 & $\begin{array}{l}\text { Intrinsic motivation for accomplishment }+ \text {, intrinsic motivation for } \\
\text { stimulation }+ \text {, time since retirement }+ \text {, anticipated satisfaction }+ \text {, } \\
\text { subjective health }+\end{array}$ & RS \\
\hline $\operatorname{Sun}^{99}$ & USA & $\mathrm{CS}$ & 734 & 67 & Loss of loved ones - & LS \\
\hline Szinovacz $^{100}$ & USA & $\mathrm{L}$ & 790 & 59.1 & $\begin{array}{l}\text { Wives employed -, age }+ \text { (for men), age - (for women), self-rated } \\
\text { health }+ \text {, household income }+ \text {, years in last job }+ \text {, forced into } \\
\text { retirement -, hours worked before retirement -, husbands influence in } \\
\text { wife's retirement - (for women), depressive symptoms, number of } \\
\text { daily activities limitations - }\end{array}$ & RS \\
\hline Taylor $^{101}$ & USA & $\mathrm{L}$ & 672 & 45.3 & $\begin{array}{l}\text { Location satisfaction }+ \text {, orientation toward } \mathrm{Navy}+\text {, work } \\
\text { characteristics }+\end{array}$ & A \\
\hline \multirow[b]{2}{*}{ Taylor $^{102}$} & \multirow[b]{2}{*}{ USA } & \multirow[b]{2}{*}{$\mathrm{L}$} & \multirow[b]{2}{*}{37} & \multirow[b]{2}{*}{61.5} & Social support + , retirement expectations + & $\mathrm{RS}$ \\
\hline & & & & & Retirement expectations + & LS \\
\hline Teuscher ${ }^{103}$ & Switzerland & $\mathrm{CS}$ & 443 & 65.4 & Identity diversity + & LS \\
\hline Tougas $^{104}$ & Canada & $\mathrm{CS}$ & 149 & - & Self-steem + , negative comparisons - & LS \\
\hline Vaillant $^{105}$ & USA & $\mathrm{L}$ & 151 & 70 & $\begin{array}{l}\text { Low neuroticism }+ \text {, adjustment }+ \text {, quality of marriage }+ \text {, job } \\
\text { satisfaction prior to retirement }+ \text {, quality of vacations during working } \\
\text { life }+ \text {, satisfaction with marriage }+ \text {, children }+ \text {, hobbies }+ \text {, community } \\
\text { service }+\end{array}$ & RS \\
\hline van Solinge ${ }^{106}$ & Netherlands & $\mathrm{L}$ & 559 & $61+$ & $\begin{array}{l}\text { Female -, involuntary retirement -, number of hours worked before } \\
\text { retirement -, anxiety with social contacts -, anxiety with social status } \\
-, \text { self-efficacy }+\end{array}$ & A \\
\hline Villar $^{107}$ & Spain & $\mathrm{CS}$ & 154 & 74.3 & $\begin{array}{l}\text { Low time for basic activities -, long time watching television -, } \\
\text { education }+ \text {, family income }+ \text {, reported health }+ \text {, time in desired } \\
\text { activities }+ \text {, time in undesired activities - }\end{array}$ & LS \\
\hline Wahrendorf $^{108}$ & Multiple & $\mathrm{CS}$ & 22777 & - & Voluntary work + , informal help + & WB \\
\hline Wang $^{109}$ & $\begin{array}{l}\text { China } \\
\text { (Taiwan) }\end{array}$ & $\mathrm{CS}$ & 454 & 62.4 & Free time management + & QoL \\
\hline
\end{tabular}




\begin{tabular}{|c|c|c|c|c|c|c|}
\hline \multirow{2}{*}{ Warr ${ }^{10}$} & \multirow{2}{*}{ England } & \multirow{2}{*}{$\mathrm{CS}$} & \multirow{2}{*}{260} & \multirow{2}{*}{60.3} & $\begin{array}{l}\text { Professional role preference }+ \text {, male }+ \text {, self-rated health }+ \text {, health } \\
\text { limitations }- \text {, opportunity for personal control }+ \text {, externally generated } \\
\text { goals -, variety }+ \text {, environmental clarity }+ \text {, physical security }+ \text {, valued } \\
\text { social position }+\end{array}$ & WB \\
\hline & & & & & $\begin{array}{l}\text { Male }+ \text {, partnered }+ \text {, opportunity for personal control }+ \text {, variety }+ \text {, } \\
\text { environmental clarity }+ \text {, availability of money }+ \text {, physical security }+ \text {, } \\
\text { quality of contact }+ \text {, valued social position }+\end{array}$ & LS \\
\hline Wong $^{111}$ & Australia & $\mathrm{CS}$ & 394 & 71.4 & $\begin{array}{l}\text { Psychological health }+ \text {, income }+ \text {, years retired }+ \text {, good conditions of } \\
\text { work exit }+ \text {, being married }+\end{array}$ & A \\
\hline $\mathrm{Wu}^{112}$ & $\begin{array}{l}\text { China } \\
\text { (Hong } \\
\text { Kong) }\end{array}$ & CS & 501 & 71.9 & $\begin{array}{l}\text { Volunteer }+ \text {, self-efficacy }+ \text {, perceived rewards from voluntary work } \\
+\end{array}$ & LS \\
\hline Yeung $^{113}$ & $\begin{array}{l}\text { China } \\
\text { (Hong } \\
\text { Kong) }\end{array}$ & $\mathrm{L}$ & 90 & 57.9 & Social life planning - , psychological planning + & WB \\
\hline Zenger $^{114}$ & Germany & $\mathrm{CS}$ & 1396 & 70 & Unemployment periods - & LS \\
\hline Zhang $^{115}$ & China & CS & 343 & 63.6 & $\begin{array}{l}\text { Age }- \text {, health responsibility }+ \text {, spiritual growth }+ \text {, physical activity }+ \text {, } \\
\text { interpersonal relationships }+ \text {, nutrition }+ \text {, stress management }+\end{array}$ & QoL \\
\hline
\end{tabular}

Abbreviations: $\mathrm{A}=$ adjustment; $\mathrm{CS}=$ cross sectional; $\mathrm{L}=$ longitudinal; $\mathrm{LS}=$ life satisfaction; $\mathrm{QoL}=$ quality of life; $\mathrm{RS}=$ retirement satisfaction;

$\mathrm{WB}=$ well being. All articles reviewed are in a reference list in Appendix; superscript numbers that accompany names in the column

"Reference" indicate the order articles appear in this reference list. 
A cross-sectional design was used in 74 studies, and a longitudinal design was used in 41 studies. Data collection stages among the longitudinal studies ranged from two to 12. All the studies used questionnaires to collect data using personal interviews, by telephone, online or mail. Only one study used daily records filled out by the participants. The average sample was 3,022 participants and the median was 447 , due some exceptionally large samples -33 ones included more than 1,000 participants and seven were larger than 10,000 . On average, participants were 65.4 years old and were retired for 5.5 years on average. These data should be interpreted with caution, since only 24 studies reported the average time since retirement.

Most of the studies, $n=64$, used only primary data; another 46 studies used only secondary data; and five studies used both primary and secondary data. Secondary sources were primarily large databases concerning aging, the most frequently utilized of which were the Health and Retirement Study (HRS; $n=7)$ and the Survey of Health, Aging and Retirement in Europe (SHARE; $\mathrm{n}=4$ ). The criterion variables occurred 127 times: satisfaction with life, $\mathrm{n}=44$; satisfaction with retirement, $\mathrm{n}=29$; well-being $=$ 20; quality of life, $\mathrm{n}=20$; and adjustment $=14$. This number surpasses that of studies, $\mathrm{n}$ $=115$, because some analyses included two criterion variables.

\section{Predictors of retirement adjustment}

The 807 predictor variables identified were submitted to content analysis (Bardin, 1977) and classified into 26 categories (Table 2). Qualitative analysis requires a higher degree of subjective decisions in order to provide meaningful information, so we experimented some ways of structuring these categories. Initially we organized the predictors only according to the proportion of positive outcomes. However, it yielded a very biased classification due the number of studies on each category (e. g., physical 
health, $\mathrm{n}=94$, compared to goals, $\mathrm{n}=3$ ). Then the predictors were organized into four large groups, according to the number of papers and the proportion of evidence of positive effects on adjustment. Variables' quantitative impact was not taken into consideration to classify the predictors, only the amount of available evidence on each predictor. Group 1 gathers predictors

Predictors frequently studied and with high proportions of positive effects are gathered in Group 1 and Group 2; predictors seldom studied but with high proportions of positive effects are included in Group 3; and predictors with high proportions of null or negative effects compose Group 4. Therefore, the groups of predictors are based on the amount of supportive evidence each predictor has and diverge from the classifications used in previous reviews (França \& Murta, 2014; van Solinge, 2012; Wang \& Shultz, 2010; Wang et al., 2011; Wang \& Hesketh, 2012).

Table 2. Groups of predictors organized according to the number of studies showing positive, null, or negative effects on retirement adjustment.

\begin{tabular}{|c|c|c|c|c|c|c|c|c|}
\hline \multirow{2}{*}{ Group } & \multirow{2}{*}{ Predictor } & \multirow{2}{*}{$\mathbf{n}$} & \multicolumn{2}{|c|}{ Positive } & \multicolumn{2}{|c|}{ Null } & \multicolumn{2}{|c|}{ Negative } \\
\hline & & & $\%$ & $\mathrm{n}$ & $\%$ & $\mathrm{n}$ & $\%$ & $\mathrm{n}$ \\
\hline \multirow{6}{*}{1} & Physical health & 94 & $83 \%$ & 78 & $14,9 \%$ & 14 & $3,2 \%$ & 2 \\
\hline & Finances & 66 & $80,3 \%$ & 53 & $18,2 \%$ & 12 & $1,5 \%$ & 1 \\
\hline & $\begin{array}{l}\text { Psychological health and } \\
\text { personality-related } \\
\text { attributes }\end{array}$ & 102 & $79,4 \%$ & 81 & $19,6 \%$ & 20 & $1,0 \%$ & 1 \\
\hline & Leisure & 32 & $75,0 \%$ & 24 & $21,9 \%$ & 7 & $3,1 \%$ & 1 \\
\hline & Retirement voluntariness & 69 & $69,6 \%$ & 48 & $27,5 \%$ & 19 & $2,9 \%$ & 2 \\
\hline & Social integration & 57 & $63,2 \%$ & 36 & $33,3 \%$ & 19 & $3,5 \%$ & 2 \\
\hline \multirow{8}{*}{2} & Retirement preparation & 23 & $56,5 \%$ & 13 & $34,8 \%$ & 8 & $8,7 \%$ & 2 \\
\hline & Marital relationship & 75 & $53,3 \%$ & 40 & $38,7 \%$ & 29 & $8,0 \%$ & 6 \\
\hline & Post-retirement work & 23 & $52,2 \%$ & 12 & $39,1 \%$ & 9 & $8,7 \%$ & 2 \\
\hline & $\begin{array}{l}\text { Pre-retirement work } \\
\text { conditions }\end{array}$ & 51 & $51 \%$ & 26 & $43,1 \%$ & 22 & $5,9 \%$ & 3 \\
\hline & Spirituality & 12 & $50,0 \%$ & 6 & $50,0 \%$ & 6 & $0,0 \%$ & 0 \\
\hline & Retirement length & 15 & $46,7 \%$ & 7 & $40,0 \%$ & 6 & $13,3 \%$ & 2 \\
\hline & Parenting & 13 & $46,2 \%$ & 6 & $38,5 \%$ & 5 & $15,4 \%$ & 2 \\
\hline & Education & 25 & $44,0 \%$ & 11 & $52,0 \%$ & 13 & $4,0 \%$ & 1 \\
\hline \multirow{3}{*}{3} & Goals & 3 & $100,0 \%$ & 3 & $0,0 \%$ & 0 & $0,0 \%$ & 0 \\
\hline & Voluntary work & 10 & $80,0 \%$ & 8 & $20,0 \%$ & 2 & $0,0 \%$ & 0 \\
\hline & Community resources & 8 & $75,0 \%$ & 6 & $25,0 \%$ & 2 & $0,0 \%$ & 0 \\
\hline
\end{tabular}




\begin{tabular}{llccccccc}
\hline & 9 & $66,7 \%$ & 6 & $33,3 \%$ & 3 & $0,0 \%$ & 0 \\
Pamily & 5 & $60,0 \%$ & 3 & $40,0 \%$ & 2 & $0,0 \%$ & 0 \\
Professional identity & 8 & $50,0 \%$ & 4 & $37,5 \%$ & 3 & $12,5 \%$ & 1 \\
Physical activity & 38 & $23,7 \%$ & 9 & $57,9 \%$ & 22 & $18,4 \%$ & 7 \\
Age & 35 & $22,9 \%$ & 8 & $62,9 \%$ & 22 & $14,3 \%$ & 5 \\
Sex & 7 & $14,3 \%$ & 1 & $85,7 \%$ & 6 & $0,0 \%$ & 0 \\
& Living arrangements & 8 & $12,5 \%$ & 1 & $62,5 \%$ & 5 & $25,0 \%$ & 2 \\
Retirement timing & 14 & $7,1 \%$ & 1 & $85,7 \%$ & 12 & $7,1 \%$ & 1 \\
Ethnicity & 5 & $0,0 \%$ & 0 & $80,0 \%$ & 4 & $20,0 \%$ & 1
\end{tabular}

Group 1. This group includes predictors assessed in many studies $(\mathrm{n}>30)$ and with a high proportion of positive results for adjustment $(>60 \%)$. Six predictors were included: physical health, finances, psychological health and personality-related attributes, leisure, voluntary retirement, and social integration.

Physical health. This variable was the second most frequent $(\mathrm{n}=94)$, with the highest proportion of positive effects on adjustment, $81.9 \%(n=78)$. It included factors such as pre-retirement health, current health, improved health after retirement, regular exams, nutrition, physical functionality and oral health. Surprisingly, two results reported conditions in which physical health can be a risk factor for retirement: the study conducted by Nimrod, Janke, \& Kleiber (2008), in which satisfaction with health predicted lack of adjustment; and the study conducted by Potocnik, Tordera, and Peiró (2010), in which workers still apt to work became dissatisfied when they were required to retire.

Finances. Financial conditions predicted adjustment in $80.3 \%(\mathrm{n}=52)$ of the cases. This category includes net worth, personal income, family income, increase in income, and relative increase in income. Only the study conducted by Nimrod et al. (2008) presents finances as a risk factor for adjustment, indicating there is a negative association between socioeconomic status and satisfaction with life. 
Psychological health and personality-related attributes. This was the most frequent category, $n=102$ cases, and presented positive effects on adjustment in $79.4 \%$ of the retirements. Psychological conditions include factors as positive attitude toward retirement, psychological health before retirement, emotional stability, management of stress, optimism, motivation, locus of internal control, self-efficacy, self-esteem, sense of humor, and extraversion.

Leisure. The factors in this category contributed to adjustment in $75 \%$ of the cases $(n=24)$. These factors are leisure activities, activities outside the home, cultural activities, feeling of competence in leisure activities, hobbies, listening to music, reading newspapers, and the quality of vacations during professional life. Only the study conducted by Guinn (1999) showed losses associated with leisure when commitment to leisure predicted a decrease in satisfaction with life.

Voluntary retirement. In $69.6 \%$ of the occurrences $(\mathrm{n}=48)$, autonomy regarding one's decision to retire favored adjustment. This category includes factors such as personal choice, perceived ability to choose, aspirations for the period of retirement, search for personal interests, desired retirement, guidance regarding the benefits of retirement, and compatibility between expectations and professional status. In only two cases did voluntary retirement harm adjustment to retirement. In the study conducted by Hardy \& Quadagno (1995), those who accepted a special retirement plan became less satisfied. In the study conducted by Potocnik et al. (2010), pressure on the part of the organization for its employees to retire was a risk factor for those who retired voluntarily.

Social integration. This category contributed to adjustment in $63.2 \%$ of the cases $(n=36)$. Among these conditions, the following factors were included: how frequently the individual contacts friends, relevance of friendships, sources of emotional 
support, social integration, not being alone, participation in social activities, quality of relationships, and frequency of social activities. Social integration had harmful effects in two situations: interaction exclusively with same age individuals (Riquelme, Buendía, \& Ruiz, 1997) and when loved ones die (Sun, Waldron, Gitelson, \& Ho, 2011). It is important to notice that other categories, such as marriage and parenting, also refer to social integration. In order to highlight each source of interaction relevance, we excluded from social integration variables that specify interaction with husband, wife, or offspring.

Group 2. This group includes predictors assessed in an intermediary number of studies $(n>10)$ and with a moderate proportion of positive results for adjustment (between $40 \%$ and 60\%). It includes eight predictors: preparation for retirement, marital relationship, spirituality, characteristics of pre-retirement job, post-retirement job, duration of retirement, parenthood, and education.

Preparation for retirement. Activities intended to prepare someone for retirement were beneficial in $56.5 \%$ of the cases $(n=13)$, including informal preparation, such as talking to a spouse, counseling, planning leisure activities, psychological planning, or simply thinking about retirement, in addition to formal activities like attending meetings addressing retirement planning. Paradoxically, preparation was a risk factor in two cases: discussing the subject with the family (Lee and Law, 2004) and planning one's social life (Yeung, 2013).

Marital relationship. Having an intimate relationship was a protective factor in $53.3 \%$ of the cases $(n=40)$. In $38.7 \%$ of the cases, the effect on adjustment was null and in six cases, the relationship negatively affected adjustment (in three of these studies, the husband retired and the wife continued to work). 
Post-retirement job. Activities in this category were positive in $52.2 \%$ of the occurrences $(n=12)$. The examples included working full time or half time, quality of the work, and working for pleasure. Two studies, however, reported circumstances in which professional activities can be harmful and may generate dissatisfaction: remaining at work due to financial needs (Dingemans \& Henkens, 2014) and working many years after retirement (Leung \& Earl, 2012).

Characteristics of the pre-retirement job. This category was beneficial for adjustment in $51 \%$ of the cases $(n=26)$, including factors such as prestige, physical safety, social environment, stability and longer duration of one's final job. In $43 \%$ of the cases $(n=22)$, these characteristics had no impact. Three studies reported adverse conditions that promoted adjustment after retirement: low level of acknowledgment at work and a high number of unemployment periods favored satisfaction with retirement (Quick \& Moen, 1998); similarly, working for more than 50 hours a week favored wellbeing (Coursolle, Sweeney, Raymo, \& Ho, 2010).

Spirituality. This category was assessed 12 times. In half of them, the results revealed that different dimensions of spirituality - experiences, beliefs and practices positively affected satisfaction with life, quality of life, and well-being. In the other six occurrences, however, no influence was identified on retirement adjustment.

Duration of retirement. The effect of time elapsed since retirement was assessed in 15 studies. In $46.7 \%$ of them $(n=7)$, passage of time favored adjustment: participants who had been retired longer presented better quality of life, well-being, satisfaction with retirement and with life. Time had no effect in six studies and only two studies indicated time can be a risk factor for retirement, one of which assessed samples in the United States and Israel (Nimrod et al., 2008), while the other assessed a Swedish sample (Nordenmark \& Stattin, 2009). 
Parenting. This category includes interaction with parents from younger generations and was assessed in 13 studies. In $46.2 \%$ of them $(n=6)$, it positively affected retirement adjustment in situations such as: being a father or mother; having children at home; interacting with children or grandchildren; and satisfaction with children. In five cases, parenthood had no effect and, in two cases, it presented an adverse impact associated with the existence of dependent children (Kim \& Feldman, 2000; Marshall, Clarke, \& Ballantyne, 2001).

Education. The participants' levels of education were assessed 25 times. This variable promoted adjustment in $44 \%$ of the cases $(n=11)$, but did not affect the remaining 13. In another study (Clarke, Marshall, \& Weir, 2012), educational level was harmful to life satisfaction.

Group 3. This group includes predictors assessed in a small number of studies ( $\mathrm{n} \leq 10)$ with a high proportion of positive results for adjustment $(\geq 50 \%)$. It encompasses six predictors: community resources, volunteer work, family, professional identity, goals and physical activity.

Goals. This category was assessed three times in two studies. All the characteristics assessed - having internally generated goals, flexibility of goals and seeking goals persistently - were predictors of well-being during retirement.

Volunteer work. Volunteer work was assessed in 10 studies. In eight of them, it was a predictor of quality of life, satisfaction with life and well-being. And in two studies, it did not affect adjustment.

Community resources. These factors were addressed in eight studies and positively affected adjustment in six cases, including environmental clarity, having a greater variety of opportunities, living in rural areas, satisfaction with community services, and satisfaction with means of transportation. The effect of community 
resources assessed in two studies addressing type of housing and access to community resources was null.

Family. The influence of the family was assessed in nine studies and favored adjustment in six of them: having family members, having siblings, family support, valuing the family, family origin, and interference of work in family life. The influence of the family on retirement was null in another three studies. It is important to notice that this category is not clearly defined in original articles and, consequently, overlaps with marriage and parenting. We kept these three different categories because it is more informative than labeling the three of them as family.

Professional identity. Professional identity was assessed in five cases and was a protective factor in three situations: personal orientation to the company, frequently mentioning professional activity and satisfaction with work before retirement. The two studies that assessed the importance of work and positive assessment of professional experiences did not find a significant effect on adjustment.

Physical activity. This category was assessed in eight studies and was identified as a protective factor for retirement in four of them. These studies examined whether the participants exercised and how frequently they did so. Three studies did not find a significant effect on adjustment, while Lee and Hung (2011) reports that intense physical activity can be a risk factor.

Group 4. This group includes variables that presented mainly null or negative effects on retirement adjustment, regardless the number of studies. It encompasses six variables: age, sex, household composition, point in time of retirement, ethnicity and others.

Age. Even though age was verified in 96 of the 115 cases, its influence on adjustment was assessed in only 38 of the final statistical models. In $57.9 \%$ of these 
cases $(n=22)$, it presented a null effect. In seven studies, the younger participants presented better adjustment, while older participants reported better adjustment in nine studies.

Sex. This category was verified in 103 of the studies, but its effect on adjustment was assessed in only 35 of the final statistical models. In $62.9 \%$ of the cases $(n=22)$, sex presented no effect on the criterion variables. In the remaining 13 studies, the results were contradictory: both sexes were predictors of better adjustment in some of the studies and predictors of worse adjustment in others.

Household composition. Living together with other people was assessed in seven cases. In six of them, the number of people did not predict adjustment during retirement; in only one study, that conducted by Nordenmark and Stattin (2009), did the participants who lived alone present worse well-being compared to those living with other people.

Time of retirement. The age the individual retired was assessed eight times, and in five times, it did not influence adjustment. Two studies, which assessed age three times, reported contradictory results concerning the time of retirement: early retirement (Fernández, Crego, \& Alcover, 2008), as well as late retirement, or later than the time that was planned (Quick \& Moen, 1998), may harm satisfaction.

Ethnicity. This variable was assessed in 14 studies and did not present effects on adjustment in 12 of them. Price and Balaswamy (2009), however, studied a sample of 330 North Americans and determined that the members of ethnic minorities were betteradjusted to retirement. On the other hand, the study conducted by Edén et al. (1998), with 376 Swedish inhabitants, identified adjustment problems among immigrants.

Others. This category includes variables that do not fit in any other group: when one makes the decision to retire; personal history of negative or positive circumstances; 
stressful events in life; and opportunities to use personal skills. None of these factors presented significant effect on retirement adjustment.

\section{Discussion}

The objective of this study was to perform a systematic review on retirement adjustment predictors. A content analysis based on the predictor variables studied in the reviewed articles pointed a total of 26 categories of predictors. These categories were organized into four groups according to two criteria: the number of studies evaluating each predictor and the proportion of positive effects each predictor had on retirement adjustment.

Group 1 included variables frequently studied and with a greater proportion of evidence concerning benefits for retirement adjustment: physical health, finances, psychological health and personality-related attributes, leisure, voluntary retirement and social integration. These results match the findings of other reviews on the topic (França \& Murta, 2014; van Solinge, 2012; Wang \& Shultz, 2010; Wang et al., 2011; Wang \& Hesketh, 2012). Interestingly these variables also overlap four of the six best predictors of national happiness: PIB per capita; social support; healthy life expectancy; freedom to make important choices (Helliwell, Layard, \& Sachs, 2015).

Group 2 included eight variables: activities aiming retirement preparation; gradual retirement; marital relationships; parenthood; characteristics of pre-retirement job; education; spirituality; and duration of retirement. Even though these factors are present in a large number of studies, they presented a lower proportion of evidence regarding benefits to adjustment. Other reviews (França \& Murta, 2014; van Solinge, 2012; Wang \& Shultz, 2010; Wang et al., 2011; Wang \& Hesketh, 2012) have already discussed most of these factors. Spirituality and duration of retirement, however, appeared for the first time as relevant predictors of adjustment to retirement. 
Surprisingly, activities that prepare to retirement were not among the best predictors of retirement adjustment, an important conclusion for the literature on retirement preparation.

Group 3 included predictors that are seldom investigated but present promising results: volunteer work, family ties, professional identity, goals, physical activity, and community resources. Among the reviews previously mentioned, only Wang and Shultz (2010) discussed the relevance of community factors.

Group 4 included factors with mixed or scarce impact on adjustment: age, sex, household composition, retirement timing, and ethnicity. It is possible, however, that these results were affected by the interaction of moderator variables.

Some studies found unexpected results. Nimrod et al. (2008) identified negative effects of health and finances on adjustment, what may raise questions about sample characteristics. Funkhouser et al. (2008) assumed the ability to discriminate between dream and reality as a risk factor for quality of life, but the results showed this is a healthy ability. Guinn (1999) reported that commitment to leisure can be dysfunctional, an effect they attributed to excessive commitment. Riquelme et al. (1997) found negative effects of socialization among elderly individuals, a potential effect of exposure to peer's physical and social losses.

Discrepant results were also found in regard to other factors. Lee \& Law (2004) showed that discussing retirement plans with family can be harmful, perhaps due the interference of family pre-existing problems. Yeung (2013) reported that planning one's social life may be harmful, possibly because it would make solitary people even more vulnerable. Two studies reported that adverse work conditions - low levels of professional acknowledgement and periods of unemployment (Quick \& Moen, 1998), and having a weekly workload above 50 hours (Coursolle et al., 2010) - may benefit 
adjustment, probably by eliminating prior adverse conditions. Finally, Nimrod et al. (2008b) and Nordenmark (2009) found that longer retirement can impair satisfaction, what could result from health getting worse over time due aging.

An important issue relative to research methods is worth discussing. Except by Kuo, Chew, \& Hooi (2007), all studies are based on self-report data, a situation already noticed in psychology field (Baumeister, Vohs, \& Funder, 2007). These authors reviewed all studies published in the Journal of Personality and Social Psychology between 1966 and 2006. They found that the proportion of publications based on behavioral measures fell from $80 \%$ to $25 \%$ between 1970 and 1980 . In 2006 , it was below 20\%. The scarcity of studies assessing behavior directly is a serious issue: in addition to the low correlation of cognitive and affective assessments with behavior, the field of psychology has been restricted to phenomena that is feasible to be studied through self-report methods. Assessing subjective evaluations exclusively through indirect measures does not clarify how subjective evaluations and behavior are connected. Without this information, interventions do not have specific behaviors to target in order to prevent dysfunctional outcomes or promote healthy effects.

\section{Limitations, Contributions, and Implications}

The method used in this review has three limitations that may interfere in the results validity. The first one involves online databases data: some articles that fit search criteria may not appear in search results. For example, three relevant articles on retirement adjustment (Pinquart \& Schindler, 2007; van Solinge \& Henkens, 2008; Wang, 2007) did not appear in our search. The second limitation refers to the use of results frequency to classify and compare predictors. Under ideal conditions, it is possible to calculate effect sizes and compare predictors effectiveness (Ferguson, 2009). In the reviewed studies, however, methodological variations do not allow to calculate 
effect sizes. The third limitation regards to publication bias (Dwan et al., 2008): published papers tend to present positive or significant results and omit non-significant results. This fact favors overestimation of effects and the maintenance of ghost theories, which retain popularity even without empirical bases (Ferguson \& Heene, 2012).

This review provides two conceptual contributions. One relates to the systematic search for papers. Even though most predictors were previously identified (França \& Murta, 2014; van Solinge, 2012; Wang et al., 2011; Wang \& Hesketh, 2012; Wang \& Shultz, 2010), a systematic search increases the credibility of results. It adds to the resource-based dynamic perspective (Wang, Henkens, \& van Solinge, 2011) with a more complete and empirically based list of resources that may help promote adjustment to retirement. The other relates to an empirical basis to compare predictors. It is possible to know how many studies there are on each predictor, and what are the overall effects of each predictor on retirement adjustment.

In addition to the conceptual advancements, this review also offers practical contributions. It reveals what we know and what we don't know about adjustment predictors and helps avoiding the redundant replication of consolidated results. Also, it has implications for retirement preparation field. For example, prevention programs aim to optimize participants financial and social resources. Then it might be appropriate to focus interventions on promoting some of Group 1 variables, such as health, finances and leisure, then on promoting many variables from the other groups, such as community resources and volunteer work.

Finally, classifying predictors according to their empirical basis provides a more consistent basis for developing theoretical and empirical models. For example, the five previous reviews on retirement adjustment point that individual attributes compose a group of relevant predictors, including physical health (Wang et al., 2011), marital 
relationship (França \& Murta, 2014), financial goal clarity (Wang \& Hesketh, 2012), age (van Solinge, 2012), and sex (Wang \& Shultz, 2010). However, according to the empirical evidence, these individual attributes have different roles on adjustment: physical health is a Group 1 predictor, marital relationship is a Group 2 predictor, financial goal clarity is a Group 3 predictor, sex and age are Group 4 predictors. Then, promoting resources with greater empirical basis may lead to the development of either more reliable or more effective interventions. And it also eases intervention adaptation to different institutions or communities. Group 1, for example, shows six different resources with the best empirical basis. It makes possible to implement an intervention in different contexts by preserving its basic elements but selecting the target predictors according to local needs and availability.

These theoretical and empirical contributions help design a research agenda concerning retirement adjustment. First, new studies investigating Group 3 variables could clarify if their effects are consistent. The six variables in this group show positive effects on adjustment to life in retirement, suggesting more investigation may be promising. Second, it is unclear how context may influence variables impact, mainly in Groups 1, 2 and 3. Researchers have been warning against searching for absolute positive or negative effects for a long time (Paul, 1967; Wang et al., 2011). It is necessary to examine the effect of potential moderator variables, such as country, profession before retiring, and changes in resources availability. Third, retirement preparation surprisingly is not among the strongest predictors of retirement adjustment. Considering that a pragmatic science aims to predict and influence behavior (Pepper, 1942), it is essential to develop more effective retirement preparation interventions and evaluating personal and contextual variables may provide some answers (Earl, Bednall, \& Muratore, 2015). Fourth, it is important to improve data collection by 
including methods different from self-report, such as assessing behavior directly. Triangulation helps validate data, making conclusions more reliable and generalizable (Creswell, 1998). At last, from a contextual perspective, individual factors are pivotal to understanding behavior but are not sufficient. To extend the knowledge on retirement adjustment predictors, it is necessary to investigate institutional, social and cultural elements, such as company retirement politics and social perception of retiree's role in community.

For decades, researchers have investigated retirement adjustment. More then ever, our times still incite us to build a world better suited for those who work a lifetime and make it to retirement. We hope this study to be a step forward it, helping promote better quality of life for those to whom life presents this opportunity.

\section{References}

Atchley, R. C. (1976). The sociology of retirement. New York: John Wiley \& Sons.

Atchley, R. C. (1999). Continuity theory, self, and social structure. In C. D. Ryff \& V. W. Marshall (Eds.), Families and retirement (pp. 145-158). Newbury Park, CA: Sage.

Bardin, L. (1977). Análise de conteúdo. Lisboa, Portugal: Edições 70.

Bartholomew, L. K., Parcel, G. S., Kok, G., Gottlieb, N. H., \& Fernández, M. E. (2011). Planning health promotion programs: An intervention mapping approach (3rd ed.). San Francisco, CA: Jossey Bass.

Baumeister, R. F., Vohs, K. D., \& Funder, D. C. (2007). Psychology as the science of self-reports and finger movements: Whatever happened to actual behavior? Perspectives on Psychological Science, 2(4), 396-403. doi:10.1111/j.17456916.2007.00051.x 
Beehr, T. A., Bennett, M. M. (2015). Working after retirement: Features of bridge employment and research directions. Work, Aging and Retirement, 1(1), 112-128. doi: 10.1093/workar/wau007

Bonsang, E., \& Klein, T. J. (2012). Retirement and subjective well-being. Journal of Economic Behavior \& Organization, 83(3), 311-329. doi:10.1016/j.jebo.2012.06.002

Clarke, P., Marshall, V. W., \& Weir, D. (2012). Unexpected retirement from full time work after age 62: Consequences for life satisfaction in older Americans. European Journal, 9, 207-219. doi:10.1007/s10433-012-0229-5

Costa, D. L. (1998). The evolution of retirement: An american economic history 18801990. Chicago: University of Chicago Press.

Coursolle, K. M., Sweeney, M. M., Raymo, J. M., \& Ho, J. (2010). The association between retirement and emotional well-being: Does prior work-family conflict matter? Journal of Gerontology: Social Sciences, 65B(5), 609-620. doi:10.1093/geronb/gbp116

Creswell, J. W. (1998). Qualitative inquiry and research design: Choosing among five traditions. Thousand Oaks, CA: Sage Publications.

Denton, F. T., \& Spencer, B. G. (2009). What is retirement? A review and assessment of alternative concepts and measures. Canadian Journal on Aging, 28(1), 63-76. doi:10.1017/S0714980809090047

Dingemans, E., \& Henkens, K. (2014). Involuntary retirement, bridge employment, and satisfaction with life: A longitudinal investigation, 591, 575-591. doi:10.1002/job

Dwan, K., Altman, D. G., Arnaiz, J. a., Bloom, J., Chan, A. W., Cronin, E., ... Williamson, P. R. (2008). Systematic review of the empirical evidence of study 
publication bias and outcome reporting bias. PLoS ONE, 3(8). doi:10.1371/journal.pone.0003081

Earl, J. K., Bednall, T. C., Muratore, A. M. (2015. A matter of time: Why some people plan for retirement and others do not. Work, Aging and Retirement, 1(2), 181-189. doi: 10.1093/workar/wau005

European Comission. (2015). The 2015 ageing report: Economic and budgetary projections for the 28 EU Member States (2013-2060). Luxembourg. doi: $10.2765 / 877631$

Ferguson, C. J. (2009). An effect size primer: A guide for clinicians and researchers. Professional Psychology: Research and Practice, 40(5), 532-538. doi:10.1037/a0015808

Ferguson, C. J., \& Heene, M. (2012). A vast graveyard of undead theories: Publication bias and psychological science's aversion to the null. Perspectives on Psychological Science, 7(6), 555-561. doi:10.1177/1745691612459059

Fernández, J., Crego, A., \& Alcover, C. (2008). Relaciones entre factores sociodemográficos, motivación hacia el retiro temprano y satisfacción en la vida post-laboral. Revista de Psicología Del Trabalho Y de Las Organizaciones, 24(3), 417-439.

França, C. L., \& Murta, S. G. (2014). Fatores de risco e de proteção na adaptação à aposentadoria. Psicologia Argumento, 32(76), 33-43.

Funkhouser, A. T., Würmle, O., Carnes, K., Locher, P., \& Bahro, M. (2008). Boundary Questionnaire results and dream recall among persons going through retirement. International Journal of Dream Research, 1(2), 34-38.

Guinn, B. (1999). Leisure behavior motivation and the life satisfaction of retired persons. Activities, Adaptation \& Aging, 23(4), 13-20. doi:10.1300/J016v23n04 
Hardy, M. A., \& Quadagno, J. (1995). Satisfaction with early retirement: Making choices in the auto industry, 50(4), 217-228.

Hayflick, L. (2007). Biological aging is no longer an unsolved problem. Annals of the New York Academy of Sciences, 1100, 1-13. http://doi.org/10.1196/annals.1395.001

Heaven, B., Brown, L. J. E., White, M., Errington, L., Mathers, J. C., \& Moffatt, S. (2013). Supporting well-being in retirement through meaningful social roles: systematic review of intervention studies. The Milbank Quarterly, 91(2), 222-87. doi:10.1111/milq.12013

Helliwell, J., Layard, R., \& Sachs, J. (2015). World happiness report 2015. New York. Retrieved from http://eprints.lse.ac.uk/47487/.

Hershey, D. A., Mowen, J. C., \& Jacobs-Lawson, J. M. (2003). An experimental comparison of retirement planning intervention seminars. Educational Gerontology, 29(4), 339-359. doi:10.1080/713844333

Hesketh, B., Griffin, B., Dawis, R., Bayl-Smith, P. (2015). Extensions to the dynamic aspects of the retirement transition and adjustment framework (RTAF): Adjustment behaviors, work styles, and identity. Work, Aging and Retirement, 1(1), 79-91; doi: 10.1093/workar/wau004

Hobfoll, S. E. (2002). Social and psychological resources and adaptation. Review of General Psychology, 6, 307-324. doi:10.1037/ 1089-2680.6.4.307

Kim, S., \& Feldman, D. C. (2000). Working in retirement: The antecedents of bridge employment and its consequences for quality of life in retirement. The Academy of Management Journal, 43(6), 1195-1210 
Kühberger, A., Fritz, A., \& Scherndl, T. (2014). Publication bias in psychology: A diagnosis based on the correlation between effect size and sample size. PLOS ONE, 9(9), 1-8. doi:10.1371/journal.pone.0105825

Kuo, A., Chew, W. H., \& Hooi, W. C. (2007). Occupations of healthy Asian retirees. Activities, Adaptation \& Aging, 31(3), 1-12. doi:10.1300/J016v31n03

Lawton, G. (1941). After sixty-five? Mental Hygiene, 25, 414-419.

Lee, W. K. M., \& Law, K. W.-K. (2004). Retirement planning and retirement satisfaction: The need for a national retirement program and policy in Hong Kong. Journal of Applied Gerontology, 23(3), 212-233. doi:10.1177/0733464804268591

Lee, Y.-J., \& Hung, W.-L. (2011). The relationship between exercise participation and well-being of the retired elderly. Aging \& Mental Health, 15(7), 873-81. doi:10.1080/13607863.2011.569486

Leung, C. S. Y., \& Earl, J. K. (2012). Retirement Resources Inventory: Construction, factor structure and psychometric properties. Journal of Vocational Behavior, 81(2), 171-182. doi:10.1016/j.jvb.2012.06.005

Marshall, V. W., Clarke, P. J., \& Ballantyne, P. J. (2001). Instability in the retirement transition: Effects on health and well-being in a Canadian study. Research on Aging, 23(4), 379-409. doi:10.1177/0164027501234001

Murta, S. G., Moura, S. A., França, C. L., Pedralho, M., Seidl, J., Lira, N. de P. M., ... Gunther, I. de A. (2014). Preparação para a aposentadoria: Implementação e avaliação do programa Viva Mais! Revista Psicologia: Reflexão e Crítica

National Center for Health Statistics. (2014). Mortality in the United States, 2013. $\begin{array}{llll}\text { NCHS Data } & \text { Brief. } & \text { Retrieved }\end{array}$ http://www.cdc.gov/nchs/data/databriefs/db168.pdf. 
National Vital Statistics System. (2011). United States Life Tables, 2007. National Vital $\begin{array}{lllll}\text { Statistics } & \text { Reports } & \text { (Vol. 59). } & \text { Retrieved }\end{array}$ http://www.cdc.gov/nchs/data/nvsr/nvsr58/nvsr58_10.pdf.

Nimrod, G., Janke, M. C., \& Kleiber, D. A. (2008). Retirement, activity, and subjective well-being in lsrael and the Unites States. World Leisure, 1, 18-32. doi:10.1080/04419057.2008.9674524

Nordenmark, M., \& Stattin, M. (2009). Psychosocial wellbeing and reasons for retirement in Sweden. Ageing and Society, 29(03), 413. doi:10.1017/S0144686X08008179

Olesen, K., Rod, N. H., Madsen, I. E. H., Bonde, J. P., \& Rugulies, R. (2015). Does retirement reduce the risk of mental disorders? Occupational and Environmental Medicine, 72(5), 366-372. doi:10.1136/oemed-2014-102228

Organisation for Economic Co-operation and Development. (2013). Pensions at a Glance 2013 OECD and G20 indicators. doi:10.1787/pension_glance-2013-en.

Paul, G. L. (1967). Strategy of Outcome Research in Psychotherapy. Journal of Consulting Psychology, 31(2), 109-118.

Pepper, S. C. (1942). World hypotheses. Berkeley: University of Califomia Press.

Pinquart, M., \& Schindler, I. (2007). Changes of life satisfaction in the transition to retirement: A latent-class approach. Psychology and Aging, 22(3), 442-55. http://doi.org/10.1037/0882-7974.22.3.442

Potočnik, K., Tordera, N., \& Peiró, J. M. (2010). The influence of the early retirement process on satisfaction with early retirement and psychological well-being. The International Journal of Aging and Human Development, 70(3), 251-273. doi:10.2190/AG.70.3.e 
Price, C. A., \& Balaswamy, S. (2009). Beyond health and wealth: Predictors of women's retirement satisfaction. The International Journal of Aging and Human Development, 68(3), 195-214. doi:10.2190/AG.68.3.b

Quick, H. E., \& Moen, P. (1998). Gender, employment, and retirement quality: A life course approach to the differential experiences of men and women. Journal of Occupational Health Psychology, 3(1), 44-64.

Riquelme, A., Buendía, J., \& Ruiz, J. (1997). Factores sociales, adaptación y bienestar subjetivo tras la jubilación.

Settersten, R. A. (2003). Invitation to the life course: The promise. In R. A. Settersten Jr. (Ed.), Invitation to the life course: Toward new understandings of later life (pp. 1-12). Amityville, NY: Baywood.

Sim, J., Bartlam, B., \& Bernard, M. (2011). The CASP-19 as a measure of quality of life in old age: Evaluation of its use in a retirement community. Quality of Life Research, 20(7), 997-1004. http://doi.org/10.1007/s11136-010-9835-x

Snyder, C. R., \& Lopez, S. J. (2009). Oxford Handbook of Positive Psychology. New York, NY: Oxford University Press.

Sun, F., Waldron, V., Gitelson, R., \& Ho, C. -h. (2011). The effects of loss of loved ones on life satisfaction among residents in a southwest retirement community: The mediating roles of social connectedness. Research on Aging, 34(2), 222-245. doi:10.1177/0164027511417594

Szinovacz, M. E., \& Davey, A. (2004). Honeymoons and joint lunches: Effects of retirement and spouse' s employment on depressive symptoms, 59(5), 233-245.

United Nations. (2013). World Population Ageing 2013. New York. Retrieved from http://bit.ly/1ONQFUA. 
van Solinge, H., \& Henkens, K. (2008). Adjustment to and satisfaction with retirement: Two of a kind? Psychology and Aging, 23(2), 422-34. http://doi.org/10.1037/08827974.23 .2 .422

van Solinge, H. (2012). Adjustment to retirement. In The Oxford Handbook of Retirement (pp. 311-24).

Vilardaga, R., Hayes, S., Levin, M., \& Muto, T. (2009). Creating a strategy for progress: A contextual behavioral science approach. The Behavior Analyst, 32(1), $105-33$.

Villar, F., Triadó, C., Solé, C., \& Osuna, M. J. (2006). Patrones de actividad cotidiana en personas mayores: ¿Es lo que dicen hacer lo que desearían hacer? Psicothema, $18(1), 149-155$.

Wang, M. (2007). Profiling retirees in the retirement transition and adjustment process: Examining the longitudinal change patterns of retirees' psychological well-being. The Journal of Applied Psychology, 92(2), 455-74. http://doi.org/10.1037/00219010.92 .2 .455

Wang, M., Henkens, K., \& van Solinge, H. (2011). A review of theoretical and empirical advancements. The American Psychologist, 66(3), 204-13. doi:10.1037/a0022414.

Wang, M., \& Hesketh, B. (2012). Achieving well-being in retirement: Recommendations from 20 years of research. SIOP White Paper Series.

Wang, M., \& Shi, J. (2014). Psychological research on retirement. Annual Review of Psychology, 65, 209-233. doi:10.1146/annurev-psych-010213-115131

Wang, M., \& Shultz, K. S. (2010). Employee Retirement: A Review and Recommendations for Future Investigation. Journal of Management, 36(1), 172206. doi: $10.1177 / 0149206309347957$ 
Wholey, J. S., Hatry, H. P., \& Newcomer, K. E. (2010). Handbook of practical program evaluation (3rd ed.). San Francisco: Jossey Bass.

Wilson, D. S., \& Gowdy, J. M. (2013). Evolution as a general theoretical framework for economics and public policy. Journal of Economic Behavior \& Organization, 90, S3-S10. http://doi.org/10.1016/j.jebo.2012.12.008

Wilson, D. S., Hayes, S. C., Biglan, A., \& Embry, D. D. (2014). Evolving the future: Toward a science of intentional change. Behavioral and Brain Sciences, 37(4), $395-416$.

Yeung, D. Y. (2013). Is pre-retirement planning always good? An exploratory study of retirement adjustment among Hong Kong Chinese retirees. Aging \& Mental Health, 17(3), 386-93. doi:10.1080/13607863.2012.732036

\section{Appendix}

1. Alpass, F., Towers, A., Stephens, C., Fitzgerald, E., Stevenson, B., \& Davey, J. (2007). Independence, well-being, and social participation in an aging population. Annals of the New York Academy of Sciences, 1114, 241-50. http://doi.org/10.1196/annals.1396.009

2. Asebedo, S. D., \& Seay, M. C. (2014). Positive psychological attributes and retirement satisfaction. Journal of Financial Counseling and Planning, 25(2), 161173.

3. Austrom, M., Perkins, A. J., Damush, T. M., \& Hendrie, H. C. (2003). Predictors of life satisfaction in retired physicians and spouses. Social Psychiatry and Psychiatric Epidemiology, 38(3), 134-41. http://doi.org/10.1007/s00127-003-0610-y

4. Ballew, S. H., Hannum, S. M., Gaines, J. M., Marx, K. a, \& Parrish, J. M. (2012). The role of spiritual experiences and activities in the relationship between chronic 
illness and psychological well-being. Journal of Religion and Health, 51(4), 138696. http://doi.org/10.1007/s10943-011-9498-0

5. Barrett, G. F., \& Kecmanovic, M. (2013). Changes in subjective well-being with retirement: Assessing savings adequacy. Applied Economics, 45(35), 4883-4893. http://doi.org/10.1080/00036846.2013.806786

6. Becchetti, L., Ricca, E. G., \& Pelloni, A. (2012). The relationship between social leisure and life satisfaction: Causality and policy implications. Social Indicators Research, 108(3), 453-490. http://doi.org/10.1007/s11205-011-9887-5

7. Bender, K. a. (2012). An analysis of well-being in retirement: The role of pensions, health, and "voluntariness" of retirement. The Journal of Socio-Economics, 41(4), 424-433. http://doi.org/10.1016/j.socec.2011.05.010

8. Benyamini, Y., Leventhal, H., \& Leventhal, E. a E. a. (2004). Self-rated oral health as an independent predictor of self-rated general health, self-esteem and life satisfaction. Social Science \& Medicine (1982), 59(5), 1109-16. http://doi.org/10.1016/j.socscimed.2003.12.021

9. Berninger, A., Webber, M. P., Weakley, J., Gustave, J., Zeig-Owens, R., Lee, R., ... Prezant, D. J. (2010). Quality of life in relation to upper and lower respiratory conditions among retired 9/11-exposed firefighters with pulmonary disability. Quality of Life Research, 19(10), 1467-76. http://doi.org/10.1007/s11136-0109710-9

10. Bonsang, E., \& Klein, T. J. (2012). Retirement and subjective well-being. Journal of Economic Behavior \& Organization, 83(3), 311-329. http://doi.org/10.1016/j.jebo.2012.06.002

11. Brajković, L., Gregurek, R., Kusević, Z., Ratković, A. S., Bras, M., \& Dordević, V. (2011). Life satisfaction in persons of the third age after retirement. Collegium 
Antropologicum, 35(3), 665-71. $\quad$ Retrieved from http://www.ncbi.nlm.nih.gov/pubmed/22053539

12. Bretherton, S. J., \& McLean, L. A. (2014). Interrelations of stress, optimism and control in older people's psychological adjustment. Australasian Journal on Ageing. http://doi.org/10.1111/ajag.12138

13. Butkovic, A., Brkovic, I., \& Bratko, D. (2012). predicting well-being from personality in adolescents and older adults. Journal of Happiness Studies, 13(3), 455-467. http://doi.org/10.1007/s10902-011-9273-7

14. Cadenas-Salazar, R., Villarreal-Ríos, E., Vargas-Daza, E. R., Martínez-González, L., \& Galicia-Rodríguez, L. (2009). Relación entre apoyo social funcional y satisfacción vital del adulto mayor jubilado. Rev Med Inst Mex Seguro Soc, 47(3), $311-314$

15. Calasanti, T. M. (1996). Gender and life satisfaction in retirement: An assessment of the male model. The Journals of Gerontology. Series B, Psychological Sciences and Social Sciences, 51(1), S18-29. Retrieved from http://www.ncbi.nlm.nih.gov/pubmed/8548520

16. Calvo, E., Haverstick, K., \& Sass, S. a. (2009). gradual retirement, sense of control, and retirees' happiness. Research on Aging, 31(1), 112-135. http://doi.org/10.1177/0164027508324704

17. Cantisano, G. T., Depolo, M., León, J. A. M., \& Morales, F. (2009). Empleo puente y bienestar personal de los jubilados: Un modelo de ecuaciones estructurales con una muestra europea probabilística. Psicothema, 21(2), 280-287.

18. Chiang, H.-H., Chien, L.-H., Lin, J.-S., Yeh, Y.-H., \& Lee, T. S.-H. (2013). Modeling psychological well-being and family relationships among retired older 
people in Taiwan. International Journal of Mental Health Nursing, 22(1), 93-101. http://doi.org/10.1111/j.1447-0349.2012.00840.x

19. Choi, N. G. (2001). Relationship between life satisfaction and postretirement employment among older women. Int J Aging Hum Dev, 52(1), 45-70. http://doi.org/10.2190/2W25-DH9H-2F4D-7HWX

20. Clarke, P., Marshall, V. W., \& Weir, D. (2012). Unexpected retirement from full time work after age 62: Consequences for life satisfaction in older Americans. European Journal of Ageing, 9(3), 207-219. http://doi.org/10.1007/s10433-012$0229-5$

21. Coursolle, K. M., Sweeney, M. M., Raymo, J. M., \& Ho, J. (2010). The association between retirement and emotional well-being: Does prior work-family conflict matter? Journal of Gerontology, 65B(5), 609-620. http://doi.org/10.1093/geronb/gbp116.

22. De Vaus, D., Wells, Y., Kendig, H., \& Quine, S. (2007). Does gradual retirement have better outcomes than abrupt retirement? Results from an australian panel study. Ageing and Society, 27(05), 667-682. http://doi.org/10.1017/S0144686X07006228

23. Dingemans, E., \& Henkens, K. (2014). How do retirement dynamics influence mental well-being in later life? A 10-year panel study. Scandinavian Journal of Work, Environment \& Health, 41(1), 16-23. http://doi.org/10.5271/sjweh.3464

24. Dingemans, E., \& Henkens, K. (2014). Involuntary retirement, bridge employment, and satisfaction with life: A longitudinal investigation. Journal of Organizational Behavior, 35(4), 575-591. http://doi.org/10.1002/job.1914

25. Donaldson, T., Earl, J. K., \& Muratore, A. M. (2010). Extending the integrated model of retirement adjustment: Incorporating mastery and retirement planning. 
Journal of Vocational Behavior, 77(2), 279-289. http://doi.org/10.1016/j.jvb.2010.03.003

26. Dorfman, L. T. (1995). Health conditions and perceived quality of life in retirement. Health \& Social Work, 20(3), 192-9. http://doi.org/10.1093/hsw/20.3.192

27. Edén, L., Brokhöj, T., Ejlertsson, G., Leden, I., \& Nordbeck, B. (1998). Is disability pension related to quality of life? Scandinavian Journal of Social Welfare, 7(4), 300-309. http://doi.org/10.1111/j.1468-2397.1998.tb00250.x

28. Elder, H. (1999). Does retirement planning affect the level of retirement satisfaction? Financial Services Review, $8(2), \quad 117-127$. http://doi.org/10.1016/S1057-0810(99)00036-0

29. Elgarresta, I. L., Miguel, M. S. de, \& Arruabarrena, L. R. (2009). Diferentes formas de acceder a la jubilación y su relación con la salud psicológica. Revista Española de Geriatría $\quad Y \quad$ Gerontología, 44(6), 311-6. http://doi.org/10.1016/j.regg.2009.07.004

30. Farquhar, J. C., Wrosch, C., Pushkar, D., \& Li, K. Z. H. (2013). The value of adaptive regret management in retirement. International Journal of Aging \& Human Development, 76(2), 99-121. http://doi.org/10.2190/AG.76.2.a

31. Fernández, J.-J., Alcover, C.-M., \& Crego, A. (2013). Psychosocial profiles of early retirees based on experiences during post-working life transition and adjustment to retirement. Revista de Psicología Social, 28(1), 99-112. http://doi.org/10.1174/021347413804756032

32. Fernández, J., Crego, A., \& Alcover, C. (2008). Relaciones entre factores sociodemográficos, motivación hacia el retiro temprano y satisfacción en la vida 
post-laboral. Revista de Psicología Del Trabalho Y de Las Organizaciones, 24(3), $417-439$.

33. Fouquereau, E., Fernandez, A., \& Mullet, E. (1999). The retirement satisfaction inventory: Factor structure in a French sample. European Journal of Psychological Assessment, 15(1), 49-56. http://doi.org/10.1027//1015-5759.15.1.49

34. Fouquereau, E., Fernandez, A., Fonseca, A. M., Paul, M. C., \& Uotinen, V. (2005). Perceptions of and satisfaction with retirement: A comparison of six European union countries. Psychology and Aging, 20(3), 524-8. http://doi.org/10.1037/08827974.20 .3 .524

35. Funkhouser, A. T., Würmle, O., Carnes, K., Locher, P., \& Bahro, M. (2008). Boundary questionnaire results and dream recall among persons going through retirement. International Journal of Dream Research, 1(2), 34-38.

36. Gall, T. L., \& Evans, D. R. (2000). Preretirement expectations and the quality of life of male retirees in later retirement. Canadian Journal of Behavioural Science, 32(3), 187-197. http://doi.org/10.1037/h0087115

37. Gall, T. L., Evans, D. R., \& Howard, J. (1997). The retirement adjustment process: Changes in the well-being of male retirees across time. The Journals of Gerontology, Series B, 52(3), P110-7. Retrieved from http://www.ncbi.nlm.nih.gov/pubmed/9158562

38. Guinn, B. (1999). Leisure behavior motivation and the life satisfaction of retired persons. Activities, Adaptation \& Aging, 23(4), 13-20. http://doi.org/10.1300/J016v23n04

39. Hardy, M. A., \& Quadagno, J. (1995). Satisfaction with early retirement: Making choices in the auto industry. The Journals of Gerontology, Series B, 50(4), S21728. Retrieved from http://www.ncbi.nlm.nih.gov/pubmed/7606537 
40. Hershey, D. a, \& Henkens, K. (2014). Impact of different types of retirement transitions on perceived satisfaction with life. The Gerontologist, 54(2), 232-44. http://doi.org/10.1093/geront/gnt006

41. Hervé, C., Bailly, N., Joulain, M., \& Alaphilippe, D. (2012). Comparative study of the quality of adaptation and satisfaction with life of retirees according to retiring age. Psychology, 3(4), 322-327. http://doi.org/10.4236/psych.2012.34046

42. Hillman, S. (2002). Participatory singing for older people: A perception of benefit. Health Education, 102(4), 163-171. http://doi.org/10.1108/09654280210434237

43. Kim, G. R., Netuveli, G., Blane, D., Peasey, A., Malyutina, S., Simonova, G., ... Pikhart, H. (2014). Psychometric properties and confirmatory factor analysis of the CASP-19, a measure of quality of life in early old age: The HAPIEE study. Aging \& Mental Health, 19(7), 1-15. http://doi.org/10.1080/13607863.2014.938605

44. Kim, J. E., \& Moen, P. (2002). Retirement transitions, gender, and psychological well-being: A life-course, ecological model. The Journals of Gerontology, Series B, 57(3), P212-22. Retrieved from http:/www.ncbi.nlm.nih.gov/pubmed/11983732

45. Kim, S., \& Feldman, D. C. (2000). Working in retirement: The antecedents of bridge employment and its consequences for quality of life in retirement. Academy of Management Journal, 43(6), 1195-1210. http://doi.org/10.2307/1556345

46. Kirby, S. E., Coleman, P. G., \& Daley, D. (2004). Spirituality and well-being in frail and nonfrail older adults. The Journals of Gerontolog, Series B, 59(3), P1239. Retrieved from http://www.ncbi.nlm.nih.gov/pubmed/15118015

47. Knesebeck, O. Von Dem, Wahrendorf, M., Hyde, M., \& Siegrist, J. (2007). Socioeconomic position and quality of life among older people in 10 European countries: Results of the SHARE study. Ageing and Society, 27(02), 269. http://doi.org/10.1017/S0144686X06005484 
48. Kubicek, B., Korunka, C., Raymo, J. M., \& Hoonakker, P. (2011). Psychological well-being in retirement: The effects of personal and gendered contextual resources. Journal of Occupational Health Psychology, 16(2), 230-46. http://doi.org/10.1037/a0022334

49. Kuo, A., Chew, W. H., \& Hooi, W. C. (2007). Occupations of healthy Asian retirees. Activities, Adaptation \& Aging, 31(3), 1-12. http://doi.org/10.1300/J016v31n03

50. Latif, E. (2011). The impact of retirement on psychological well-being in Canada. The Journal of Socio-Economics, 40(4), 373-380. http://doi.org/10.1016/j.socec.2010.12.011

51. Lee, W. K. M., \& Law, K. W. (2004). Retirement planning and retirement satisfaction: The need for a national retirement program and policy in Hong Kong. Journal of Applied Gerontology, 23(3), 212-233. http://doi.org/10.1177/0733464804268591

52. Lee, Y.-J., \& Hung, W.-L. (2011). The relationship between exercise participation and well-being of the retired elderly. Aging \& Mental Health, 15(7), 873-81. http://doi.org/10.1080/13607863.2011.569486

53. Leung, C. S. Y., \& Earl, J. K. (2012). Retirement resources inventory: Construction, factor structure and psychometric properties. Journal of Vocational Behavior, 81(2), 171-182. http://doi.org/10.1016/j.jvb.2012.06.005

54. Litwin, H., \& Shiovitz-Ezra, S. (2006). The association between activity and wellbeing in later life: What really matters? Ageing and Society, 26(02), 225. http://doi.org/10.1017/S0144686X05004538

55. Löckenhoff, C. E., Terracciano, A., \& Costa, P. T. (2009). Five-factor model personality traits and the retirement transition: Longitudinal and cross-sectional 
$\begin{array}{llll}\text { associations. Psychology and } & \text { 24(3), }\end{array}$ http://doi.org/10.1037/a0015121

56. Lowis, M. J., Edwards, A. C., \& Burton, M. (2009). Coping with retirement: Wellbeing, health, and religion. The Journal of Psychology, 143(4), 427-48. http://doi.org/10.3200/JRLP.143.4.427-448

57. Lowis, M. J., Edwards, A. C., \& Singlehurst, H. M. (2010). The relationship between preretirement occupation and older adults' life satisfaction and self-rated health. The Journal of Psychology, 145(1), 59-72. http://doi.org/10.1080/00223980.2010.526974

58. Marshall, V. W., Clarke, P. J., \& Ballantyne, P. J. (2001). Instability in the retirement transition: Effects on health and well-being in a Canadian study. Research on Aging, 23(4), 379-409. http://doi.org/10.1177/0164027501234001

59. Maule, A. J., Cliff, D. R., \& Taylor, R. (2008). Early retirement decisions and how they affect later quality of life. Ageing and Society, 16(02), 177. http://doi.org/10.1017/S0144686X00003287

60. McMunn, A., Nazroo, J., Wahrendorf, M., Breeze, E., \& Zaninotto, P. (2009). Participation in socially-productive activities, reciprocity and wellbeing in later life: Baseline results in England. Ageing \& Society, 29(05), 765-782. http://doi.org/doi:10.1017/S0144686X08008350

61. Michinov, E., Fouquereau, E., \& Fernandez, A. (2008). Retirees' social identity and satisfaction with retirement. The International Journal of Aging and Human Development, 66(3), 175-194. http://doi.org/10.2190/AG.66.3.a

62. Mimrot, B. H. (2014). The impact of gender and area of residence on adjustment of retired old person. The International Journal of Indian Psychology, 2(1). 
63. Miyakita, T., Ueda, a., Zusho, H., \& Kudoh, Y. (2002). Self-evaluation scores of hearing difficulties and quality of life components among retired workers with noise-related hearing loss. Journal of Sound and Vibration, 250(1), 119-128. http://doi.org/10.1006/jsvi.2001.3898

64. Nguyen, S., Tirrito, T. S., \& Barkley, W. M. (2014). Fear as a predictor of life satisfaction in retirement in Canada. Educational Gerontology, 40(2), 102-122. http://doi.org/10.1080/03601277.2013.802180

65. Nimrod, G. (2007). Retirees' leisure: Activities, benefits, and their contribution to life satisfaction. Leisure $\quad$ Studies, 65 (1), http://doi.org/10.1080/02614360500333937

66. Nimrod, G., \& Adoni, H. (2006). Leisure-styles and life satisfaction among recent retirees in Israel. Ageing and Society, 26(04), 607-630. http://doi.org/10.1017/S0144686X06004867

67. Nimrod, G., Janke, M. C., \& Kleiber, D. A. (2008). Retirement, activity, and subjective well-being in lsrael and the Unites States. World Leisure, 1, 18-32. http://doi.org/10.1080/04419057.2008.9674524

68. Nimrod, G., Janke, M. C., \& Kleiber, D. A. (2008). Expanding, reducing, concentrating and diffusing: Activity patterns of recent retirees in the United States. Leisure Sciences, 31(1), 37-52. http://doi.org/10.1080/01490400802558087

69. Noone, J. H., Stephens, C., \& Alpass, F. M. (2009). Preretirement planning and well-being in later life: A prospective study. Research on Aging, 31(3), 295-317. http://doi.org/10.1177/0164027508330718

70. Noone, J., O’Loughlin, K., \& Kendig, H. (2013). Australian baby boomers retiring "early": Understanding the benefits of retirement preparation for involuntary and 
voluntary retirees. Journal of Aging Studies, 27(3), 207-217. http://doi.org/10.1016/j.jaging.2013.02.003

71. Nordenmark, M., \& Stattin, M. (2009). Psychosocial wellbeing and reasons for retirement in Sweden. Ageing \& Society, 29(3), 413-430. http://doi.org/Doi $10.1017 / \mathrm{S} 0144686 \times 08008179$

72. Nuttman-Shwartz, O. (2007). Is there life without work? The International Journal of Aging and Human Development, 64(2), 129-147. http://doi.org/10.2190/0628W312-212P-H1J1

73. Oliveira, C., Torres, A. R. R., \& Albuquerque, E. S. de. (2009). Análise do bemestar psicossocial de aposentados de Goiânia. Psicologia Em Estudo, 14(7), 749757. http://doi.org/10.1590/S1413-73722009000400015

74. Pattani, S., Constantinovici, N., \& Williams, S. (2004). Predictors of reemployment and quality of life in NHS staff one year after early retirement because of ill health: A national prospective study. Occupational and Environmental Medicine, 61(7), 572-576. http://doi.org/10.1136/oem.2003.011817

75. Pimenta, F. A. P., Simil, F. F., Tôrres, H. O. G., Amaral, C. F. S., Rezende, C. F., Coelho, T. O., \& Rezende, N. A. (2008). Avaliação da qualidade de vida de aposentados com a utilizaçao do questionário SF-36. Revista Da Associaçao Médica Brasileira, 54(1), 55-60.

76. Pizzola, L., Martos, Z., Pfisterer, K., de Groot, L., \& Keller, H. (2013). Construct validation and test-retest reliability of a mealtime satisfaction questionnaire for retirement home residents. Journal of Nutrition in Gerontology and Geriatrics, 32(4), 343-59. http://doi.org/10.1080/21551197.2013.840257

77. Platts, L. G., Netuveli, G., Webb, E., Zins, M., Goldberg, M., Blane, D., \& Wahrendorf, M. (2013). Physical occupational exposures during working life and 
quality of life after labour market exit: Results from the GAZEL study. Aging \& Mental Health, 27(March 2015), 37-41. http://doi.org/10.1080/13607863.2013.781120

78. Platts, L. G., Webb, E., Zins, M., Goldberg, M., \& Netuveli, G. (2014). Mid-life occupational grade and quality of life following retirement: A 16-year follow-up of the French GAZEL study. Aging \& Mental Health, (November), 1-13. http://doi.org/10.1080/13607863.2014.955458

79. Potočnik, K., \& Sonnentag, S. (2013). A longitudinal study of well-being in older workers and retirees: The role of engaging in different types of activities. Journal of Occupational and Organizational Psychology, 86, 497-521. http://doi.org/10.1111/joop.12003

80. Potočnik, K., Tordera, N., \& Peiró, J. M. (2010). The influence of the early retirement process on satisfaction with early retirement and psychological wellbeing. The International Journal of Aging and Human Development, 70(3), 251273. http://doi.org/10.2190/AG.70.3.e

81. Price, C. A., \& Balaswamy, S. (2009). Beyond health and wealth: Predictors of women's retirement satisfaction. The International Journal of Aging and Human Development, 68(3), 195-214. http://doi.org/10.2190/AG.68.3.b

82. Price, C. A., \& Joo, E. (2005). Exploring the relationship between marital status and women's retirement satisfaction. The International Journal of Aging and Human Development, 61(1), 37-55. http://doi.org/10.2190/TXVY-HAEB-X0PW00QF

83. Quick, H. E., \& Moen, P. (1998). Gender, employment, and retirement quality: A life course approach to the differential experiences of men and women. Journal of 
Occupational Health Psychology, 3(1), 44-64. Retrieved from http://www.ncbi.nlm.nih.gov/pubmed/9552271

84. Quine, S., Wells, Y., de Vaus, D., \& Kendig, H. (2007). When choice in retirement decisions is missing: Qualitative and quantitative findings of impact on well-being. Australasian Journal on Ageing, 26(4), 173-179. http://doi.org/10.1111/j.1741$\underline{6612.2007 .00251 . x}$

85. Ramos, A. O., \& Mendoza Sierra, M. I. (2006). Bienestar subjetivo en prejubilados de Andalucía occidental. Revista Española de Geriatría Y Gerontología, 41(5), 270-276. http://doi.org/10.1016/S0211-139X(06)72972-9

86. Reitzes, D. C., \& Mutran, E. J. (2004). The transition to retirement: Stages and factors that influence retirement adjustment. International Journal of Aging \& Human Development, 59(1), 63-84. Retrieved from http://www.ncbi.nlm.nih.gov/pubmed/15453412

87. Riquelme, A., Buendia, J., \& Ruiz, J. A. (1997). Factores sociales, adaptación y bienestar subjetivo tras la jubilación. Revista Iberoamericana de Geriatría $Y$ Gerontología, 13(4), 45-51.

88. Robinson, O. C., Demetre, J. D., \& Corney, R. (2010). Personality and retirement: Exploring the links between the big five personality traits, reasons for retirement and the experience of being retired. Personality and Individual Differences, 48(7), 792-797. http://doi.org/10.1016/j.paid.2010.01.014

89. Rosenkoetter, M. M., \& Garris, J. M. (2001). Retirement planning, use of time, and psychosocial adjustment. Issues in Mental Health Nursing, 22(7), 703-22. Retrieved from http://www.ncbi.nlm.nih.gov/pubmed/11881183

90. Seligowski, A. V, Pless Kaiser, A., King, L. A., King, D. W., Potter, C., \& Spiro Iii, A. (2012). Correlates of life satisfaction among aging veterans. Applied 
Psychology. Health and Well-Being, 4(3), 261-75. http://doi.org/10.1111/j.17580854.2012.01073.x

91. Sener, a, Terzioğlu, R. G., \& Karabulut, E. (2007). Life satisfaction and leisure activities during men's retirement: A Turkish sample. Aging \& Mental Health, 11(1), 30-6. http://doi.org/10.1080/13607860600736349

92. Shultz, K. S., Morton, K. R., \& Weckerle, J. R. (1998). The influence of push and pull factors on voluntary and involuntary early retirees' retirement decision and adjustment. Journal of Vocational Behavior, 53(1), 45-57. http://doi.org/10.1006/jvbe.1997.1610

93. Sim, J., Bartlam, B., \& Bernard, M. (2011). The CASP-19 as a measure of quality of life in old age: Evaluation of its use in a retirement community. Quality of Life Research, 20(7), 997-1004. http://doi.org/10.1007/s11136-010-9835-x

94. Smith, D. B., \& Moen, P. (2004). Retirement satisfaction for retirees and their spouses: Do gender and the Retirement decision-making process matter? Journal of Family Issues, 25(2), 262-285. http://doi.org/10.1177/0192513X03257366

95. Spiegel, P. E., \& Shultz, K. S. (2003). The influence of preretirement planning and transferability of skills on naval officers' retirement satisfaction and adjustment. Military Psychology, 15(4), 285-307. http://doi.org/10.1207/S15327876MP1504_3

96. Stephan, Y. (2009). Openness to experience and active older adults' life satisfaction: A trait and facet-level analysis. Personality and Individual Differences, 47(6), 637-641. http://doi.org/10.1016/j.paid.2009.05.025

97. Stephan, Y., Fouquereau, E., \& Fernandez, A. (2008). Body satisfaction and retirement satisfaction: The mediational role of subjective health. Aging \& Mental Health, 12(3), 374-81. http://doi.org/10.1080/13607860802120839 
98. Stephan, Y., Fouquereau, E., \& Fernandez, A. (2008). The relation between selfdetermination and retirement satisfaction among active retired individuals. The International Journal of Aging and Human Development, 66(4), 329-345. http://doi.org/10.2190/AG.66.4.d

99. Sun, F., Waldron, V., Gitelson, R., \& Ho, C. (2012). The effects of loss of loved ones on life satisfaction among residents in a southwest retirement community: The mediating roles of social connectedness. Research on Aging, 34(2), 222-245. http://doi.org/10.1177/0164027511417594

100. Szinovacz, M. E., \& Davey, A. (2005). Retirement and marital decision making: Effects on retirement satisfaction. Journal of Marriage and Family, 67(2), 387398. http://doi.org/10.1111/j.0022-2445.2005.00123.x

101. Taylor, M. A., Shultz, K. S., Spiegel, P. E., Morrison, R. F., \& Greene, J. (2007). Occupational attachment and met expectations as predictors of retirement adjustment of naval officers. Journal of Applied Social Psychology, 37(8), 16971725. http://doi.org/10.1111/j.1559-1816.2007.00234.x

102. Taylor, M. A., Goldberg, C., Shore, L. M., \& Lipka, P. (2008). The effects of retirement expectations and social support on post-retirement adjustment. Journal of Managerial Psychology, 23(4), 458-470. http://doi.org/10.1108/02683940810869051

103. Teuscher, U. (2010). Change and persistence of personal identities after the transition to retirement. The International Journal of Aging and Human Development, 70(1), 89-106. http://doi.org/10.2190/AG.70.1.d

104. Tougas, F., Lagacé, M., Sablonnière, R. D. La, \& Kocum, L. (2004). A new approach to the link between identity and relative deprivation in the perspective of 
ageism and retirement. The International Journal of Aging and Human Development, 59(1), 1-23. http://doi.org/10.2190/3WTN-63QQ-EJMG-BGYA

105. Vaillant, G. E., DiRago, A. C., \& Mukamal, K. (2006). Natural history of male psychological health, XV: Retirement satisfaction. The American Journal of Psychiatry, 163(4), 682-8. http://doi.org/10.1176/appi.ajp.163.4.682

106. van Solinge, H., \& Henkens, K. (2005). Couples' adjustment to retirement: A multi-actor panel study. The Journals of Gerontology: Psychological Sciences and Social Sciences, 60B(1), S11-S20. http://doi.org/10.1093/geronb/60.1.S11

107. Villar, F., Triadó, C., Solé, C., \& Osuna, M. J. (2006). Patrones de actividad cotidiana en personas mayores: ¿Es lo que dicen hacer lo que desearían hacer? Psicothema, 18(1), 149-155.

108. Wahrendorf, M., von dem Knesebeck, O., \& Siegrist, J. (2006). Social productivity and well-being of older people: Baseline results from the SHARE study. European Journal of Ageing, 3(2), 67-73. http://doi.org/10.1007/s10433006-0028-y

109. Wang, W. C., Wu, C. Y., \& Wu, C. C. (2014). Free time management makes better retirement: A case study of retirees' quality of life in Taiwan. Applied Research in Quality of Life, 9(3), 591-604. http://doi.org/10.1007/s11482-013$9256-4$

110. Warr, P., Butcher, V., Robertson, I., \& Callinan, M. (2004). Older people's wellbeing as a function of employment, retirement, environmental characteristics and role preference. British Journal of Psychology, 95(3), 297-324. http://doi.org/10.1348/0007126041528095 
111. Wong, J. Y., \& Earl, J. K. (2009). Towards an integrated model of individual, psychosocial, and organizational predictors of retirement adjustment. Journal of Vocational Behavior, 75(1), 1-13. http://doi.org/10.1016/j.jvb.2008.12.010

112. Wu, A. M. S., Tang, C. S. K., \& Yan, E. C. W. (2005). Post-retirement voluntary work and psychological functioning among older Chinese in Hong Kong. Journal of Cross-Cultural Gerontology, 20(1), 27-45. http://doi.org/10.1007/s10823-005$3796-5$

113. Yeung, D. Y. (2013). Is pre-retirement planning always good? An exploratory study of retirement adjustment among Hong Kong Chinese retirees. Aging \& Mental Health, 17(3), 386-93. http://doi.org/10.1080/13607863.2012.732036

114. Zenger, M., Brähler, E., Berth, H., \& Stöbel-Richter, Y. (2011). Unemployment during working life and mental health of retirees: Results of a representative survey. Aging \& Mental Health, 15(2), 178-85. http://doi.org/10.1080/13607863.2010.508775

115. Zhang, S., Tao, F., Ueda, A., Wei, C., \& Fang, J. (2013). The influence of health-promoting lifestyles on the quality of life of retired workers in a mediumsized city of Northeastern China. Environmental Health and Preventive Medicine, 18(6), 458-65. http://doi.org/10.1007/s12199-013-0342-x 


\section{ESTUDO 3}

Com Quantos Pilotos se Faz uma Intervenção? Validação Social de uma Intervenção de Educação para a Aposentadoria 


\section{Resumo}

Depois de uma vida de trabalho, a expectativa pela aposentadoria resume o desejo do descanso merecido. No entanto, a literatura mostra que a aposentadoria pode gerar tanto efeitos positivos quanto negativos. Apesar disso, há poucas intervenções testadas para preparar os trabalhadores para essa transição e evitar ou minimizar o impacto negativo. Por isso, esta pesquisa apresenta um estudo de casos múltiplos com objetivo de validação social de uma intervenção sobre educação para a aposentadoria fundamentada na ciência comportamental contextual, uma estratégia de desenvolvimento científico. Em três grupos distintos, 27 indivíduos participaram de uma intervenção baseada na terapia de aceitação e compromisso, que visa a promover flexibilidade psicológica, e no modelo prossocial, que visa a promover cooperação e coesão entre membros dos grupos. De acordo com a avaliação dos participantes, a intervenção apresentou metas socialmente válidas, procedimentos socialmente aceitáveis e efeitos socialmente importantes. No entanto, ainda são necessários aprimoramentos, como o uso de métodos mais dinâmicos, formatação do material impresso e aumento da fidelidade na implementação do conteúdo e das atividades previstas. Os resultados positivos indicam que a ciência comportamental contextual pode favorecer o desenvolvimento de intervenções baseadas em componentes ativos, coesas e com evidências de validade social. A reavaliação da intervenção por meio de delineamento experimental oferecerá evidências mais adequadas sobre sua efetividade. Espera-se que, aumentando a disponibilidade de intervenções na área, este estudo favoreça um melhor ajustamento à aposentadoria.

Palavras-chave: intervenções; avaliação de processo; validade social na pesquisa; ciência comportamental contextual; modelo prossocial. 


\begin{abstract}
After a working lifetime, expecting for retirement summarizes a well-deserved rest. However, literature shows that retirement can have both positive and negative effects. Nevertheless, there are few tested interventions aimed to prepare workers for this life transition, minimizing or avoiding harmful effects. This research presents a multiplecase study with the objective of evaluating the social validity of an intervention on education for retirement based on contextual behavioral science. In three groups, 27 individuals participated in an intervention based on acceptance and commitment therapy, which aims to promote psychological flexibility, and prosocial model, which aims to promote cooperation and cohesion among group members. According to the evaluation of the participants, the intervention presented socially valid targets, socially acceptable procedures, and socially important effects. However, improvements are still necessary, as the use of more dynamic methods, printed material formatting and increasing implementation fidelity. Positive results indicate that contextual behavioral science can foster the development of interventions with high cohesion based on active components and with evidence of social validity. The replication of the intervention through experimental design may evaluate its effectiveness. We hope that increasing available interventions fosters a better adjustment to retirement.
\end{abstract}

Keywords: interventions; process evaluation; social validity in research; contextual behavioral science; prossocial model. 
Qual é o impacto da aposentadoria sobre o trabalhador? A resposta é relativa: a saúde pode melhorar ou piorar (van der Heide, van Rijn, Robroek, Burdorf, \& Proper, 2013), assim como a satisfação (Bonsang \& Klein, 2012), a vida conjugal (Szinovacz \& Davey, 2005), o contato com os filhos (Szinovacz \& Davey, 2001), o lazer (Nimrod, Janke, \& Kleiber, 2008) e a prática de atividade física (Kämpfen \& Maurer, 2016), por exemplo. Essa variabilidade deve-se à disponibilidade de recursos pessoais e contextuais antes e depois da aposentadoria que influenciam o impacto da aposentadoria sobre o ajustamento do trabalhador (Wang, Henkens, \& van Solinge, 2011). Assim, é oportuno investir em intervenções de preparação para a aposentadoria focadas na maximização dos fatores protetivos do ajustamento a essa fase da vida.

Muitos dos fatores que afetam o impacto da aposentadoria sobre o trabalhador são conhecidos, sendo os mais relevantes: saúde física, finanças, fatores psicológicos, lazer, opção voluntária pela aposentadoria e interação social (Barbosa, Monteiro, \& Murta, 2016). No entanto, poucas intervenções foram desenvolvidas e avaliadas com o objetivo de modificar esses fatores. A revisão de Leandro-França et al. (2016) consultou 13 bases de dados em busca de estudos sobre Educação para a Aposentadoria (EPA) escritos em português, espanhol ou inglês e que incluíssem descrição e avaliação de procedimentos e resultados. Abrangendo publicações anteriores a 2015, foram encontrados apenas 11 registros que atendiam aos dois critérios de inclusão, todas com intervenções grupais. Ainda assim, muitos estudos apresentavam limitações no delineamento, qualidade dos instrumentos e análises de dados pouco robustas. A escassez de intervenções adequadamente desenvolvidas e testadas desfavorece o preparo dos trabalhadores para a aposentadoria. Por sua vez, o despreparo pode aumentar a vulnerabilidade dos trabalhadores a problemas de ajustamento e redução da 
qualidade de vida. Para minimizar esse risco, desenvolver e avaliar intervenções para EPA com mais rigor é uma alternativa recomendável.

\section{Desenvolvimento de Intervenções em Prevenção e Promoção em Saúde Mental}

O desenvolvimento de intervenções é parte do ciclo de pesquisa em prevenção e promoção de saúde mental (Murta \& Santos, 2015). Esse ciclo pode ser dividido em sete etapas (Muñoz, Mrazek, \& Haggerty, 1996) relacionadas ao problema-alvo: estudos epidemiológicos, para descrever a prevalência e a incidência do problema; estudos etiológicos, para identificar fatores de risco e de proteção para o problema em questão; estudos de desenvolvimento, para construir e testar a viabilidade e aceitabilidade da intervenção; estudos de eficácia e de efetividade, para avaliar os efeitos da intervenção; e estudos de difusão e de adaptação cultural, para transferir e ajustar a intervenção a outros contextos e culturas. A etapa de desenvolvimento de intervenções, mais especificamente, pode ser dividida em três estágios (Rohrbach, 2014): fundamentação teórica, que visa a identificar o público-alvo, descrever o problema e seus determinantes a partir da teoria e definir os objetivos; construção do programa, que visa a selecionar e integrar as técnicas ao contexto e às características da população; e teste-piloto, que visa a avaliar os efeitos de atividades individuais e o desfecho geral da intervenção. Como resultado, um dos produtos esperados é a construção de uma intervenção que seja avaliada como socialmente válida.

A validade social de uma intervenção abrange a significância social das metas, a aceitabilidade social dos procedimentos e a importância social dos efeitos de uma intervenção (Wolf, 1978). Esse conceito surgiu no fim da década de 1960 como uma característica distintiva da análise aplicada do comportamento, que se diferenciava da análise experimental do comportamento por enfatizar a relevância social dos problemas estudados (Baer \& Wolf, 1987). Nos anos seguintes, o conceito se disseminou com o 
aumento da participação da comunidade nas intervenções e atualmente existem pelo menos 12 definições de validade social (Carter, 2010), que indicam formas pelas quais a sociedade pode validar as intervenções desenvolvidas por pesquisadores.

Além de contribuir para legitimar os resultados objetivos, a validade social também pode favorecer a qualidade da implementação (Lane \& Beebe-Frankenberger, 2004), aspecto da intervenção que merece atenção especial. A revisão de Durlak e DuPre (2008) identificou 23 fatores que podem influenciar a qualidade da implementação de programas preventivos e de promoção de saúde organizados em cinco categorias: fatores comunitários, como política de prevenção e promoção em saúde mental; características do provedor, como autoeficácia relativa à capacidade de implementar a intervenção; características inovadoras, como a possibilidade de adaptar a intervenção à população; capacidade organizacional, como a abertura institucional à mudança; e sistema de entrega da prevenção, como o treinamento dos profissionais que oferecem a intervenção. Baseados em uma amostra de 542 estudos, os resultados mostram que intervenções bem implementadas produzem tamanhos de efeitos cerca de duas a três vezes maiores do que intervenções com problemas de implementação. Como os autores afirmam, implementação importa. No entanto, nenhuma das intervenções revisadas por Leandro-França et al. (2016) incluiu avaliação da validade social.

\section{Uma Abordagem Sistemática para o Desenvolvimento de Intervenções}

Há seis décadas, Kurt Lewin já destacava que "não há nada tão prático quanto uma boa teoria" (Lewin, 1951, p. 169). Ela ajuda a identificar os determinantes do comportamento, o processo de mudança e orienta a escolha das técnicas de intervenção, maximizando os resultados ou apontado as alterações necessárias (Bartholomew \& Mullen, 2011). Por outro lado, a fundamentação teórica implícita e não-articulada dificulta a compreensão do funcionamento e a adaptação de uma intervenção (Herbert, 
Gaudiano, \& Forman, 2013). Esse problema pode comprometer a consistência da maior parte das intervenções sobre EPA, que não se baseia explicitamente em teorias (Leandro-França et al., 2016): dos 11 artigos revisados pelos autores, apenas cinco mencionam as teorias que orientaram o desenvolvimento da intervenção - modelo FRAMES, modelo transteórico de mudança, teoria social cognitiva, modelo da adequação da decisão sobre aposentadoria e teoria da imagem. Esse resultado mostra que o embasamento conceitual pode ser um ponto fraco dos estudos sobre EPA.

Uma maneira de superar essa limitação é utilizar princípios para guiar o desenvolvimento das diversas etapas da construção do conhecimento, favorecendo uma coesão natural entre os diferentes níveis e dimensões do conhecimento. Essa é a proposta da ciência comportamental contextual (CCC; Vilardaga, Hayes, Levin, \& Muto, 2009). A CCC é uma estratégia de desenvolvimento científico focada em princípios que promove a integração entre princípios básicos, teoria e modelos aplicados a fim de predizer e influenciar as ações de indivíduos e grupos. Seu programa de pesquisa inclui pressupostos filosóficos, teoria básica e aplicada e desenvolvimento de intervenções. Em essência, trata-se de uma aplicação sistemática, em diferentes níveis e dimensões, do pensamento contextual (Pepper, 1942).

A CCC se baseia nos pressupostos filosóficos do contextualismo funcional, um sistema pragmático caracterizado por quatro critérios essenciais (Biglan \& Hayes, 1996; Hayes, Hayes, \& Reese, 1988). Primeiro, o objetivo de predição-e-influência do comportamento - predição e influência como um objetivo único, sendo que apenas as análises que contemplam ambas as características são consideradas válidas (Hayes et al., 1988). Segundo, o ato-no-contexto como unidade básica de análise: é preciso considerar um evento na situação histórica e ambiental em que ocorre. Terceiro, a funcionalidade como critério de verdade. Independente de considerações sobre uma 
possível estrutura subjacente no mundo, consideram-se verdadeiras as análises úteis aos objetivos preestabelecidos. Em uma análise, buscam-se variáveis que permitem predizer e alterar a probabilidade de ocorrência do evento, caso possam ser manipuladas. Quarto, uma visão monista do ser humano, entendido como um organismo integral. Assim, pensamentos, sentimentos e comportamentos são considerados ações em um mesmo nível, sem hierarquia (Hayes \& Brownstein, 1986).

A CCC estende o pragmatismo às teorias, entendidas como aplicações sistemáticas e abrangentes de análises de atos-no-contexto a fim de predizer-einfluenciar ações de indivíduos e grupos (Hayes, Barnes-Holmes, \& Wilson, 2012). A teoria dos quadros relacionais (TQR; Hayes, Barnes-Holmes, \& Roche, 2001) é um exemplo de teoria básica com aplicações práticas. Trata-se de uma teoria da cognição e da linguagem humanas baseada na habilidade aprendida de relacionar símbolos arbitrariamente. Compreender a função e o contexto dessas relações permite predizer, e manipular, seu impacto subjetivo.

No nível do desenvolvimento de intervenções, a terapia de aceitação e compromisso (ACT; Barbosa \& Murta, 2014; Hayes, Strosahl, \& Wilson, 2012) é um exemplo de abordagem baseada nos princípios contextuais. A ACT é um modelo clínico de saúde e psicopatologia que visa a promover flexibilidade psicológica: a habilidade de manter ou mudar de comportamento, de maneira consciente e intencional, em função dos valores (Hayes, Luoma, Bond, Masuda, \& Lillis, 2006). Enquanto a flexibilidade resulta do uso funcional dos mecanismos psicológicos, o uso disfuncional dos mesmos mecanismos pode resultar em um funcionamento psicopatológico.

A CCC pode abranger diferentes níveis de ação (do comportamento individual à formação cultural) e áreas do conhecimento cujo funcionamento seja explicado pelos mesmos princípios contextuais. Consequentemente, a CCC também pode se beneficiar 
do conhecimento produzido nesses outros níveis e áreas. A promoção de grupos cooperativos é um exemplo disso. Na década de 1980, a cientista Elinor Ostrom começou a investigar comunidades cuja subsistência dependia de recursos compartilhados, como comunidades de pescadores e vilarejos de agricultores. Tradicionalmente, acreditava-se que a ausência de regulação externa levaria esses grupos à exaustão dos recursos e, consequentemente, à extinção do grupo. No entanto, Ostrom encontrou casos que não apenas subsistiram, mas prosperaram. Nesses grupos, ela identificou características especiais, que ficaram conhecidas como os oito princípios de Ostrom (Wilson, Ostrom, \& Cox, 2013): (1) identidade comum e propósitos claros; (2) distribuição justa de custos e benefícios; (3) tomada de decisão coletiva; (4) monitoramento de atividades consensualmente negociadas; (5) aplicação de sanções graduais, quando necessário; (6) resolução de conflitos rápida e justa; (7) autoridade para se autogovernar; e (8) relações com outros grupos. Posteriormente, esses princípios foram integrados a uma perspectiva evolucionista (Wilson, 2012), generalizados para outros contextos (Wilson et al., 2013) e organizados no modelo prossocial (Hayes, Polk, \& Wilson, 2014; Wilson, 2012), que visa a promover cooperação e aprimorar a eficácia de grupos. Embora ainda em fase inicial, a aplicação do modelo prossocial em intervenções de mudança de comportamento em larga escala é promissora (Wilson, Kauffman, \& Purdy, 2011).

Enfim, a CCC é uma estratégia abrangente para a promoção da ciência, baseia-se em princípios fundamentais e passíveis de atualização e busca integração com áreas do conhecimento que partilham princípios comuns, favorecendo o próprio desenvolvimento do conhecimento. Além da integração entre diferentes dimensões e níveis de conhecimento, a CCC também indica critérios para orientar a agenda de pesquisa científica, como mostram alguns artigos sobre o tema (Hayes, Barnes-Holmes, 
\& Wilson, 2012; Hayes, Long, Levin, \& Follette, 2013; Vilardaga, Hayes, Levin, \& Muto, 2009). Por exemplo, o estudo de Hayes et al. (2013) oferece diversas sugestões para o aprimoramento do processo de desenvolvimento de intervenções, como: coordenar pesquisa sobre intervenções e pressupostos filosóficos; ênfase em processos funcionais, que devem ser manipuláveis; planejamento da implementação e disseminação desde os estágios iniciais; adoção de modelos aplicáveis à dimensão da saúde pública; teste precoce de efetividade; e pesquisa de abrangência transdiagnóstica.

Em resumo, a área de desenvolvimento de intervenções de EPA apresenta duas lacunas importantes: escassez de estudos e construção de intervenções sem fundamentação teórica. Nesse contexto, a construção e validação social de uma intervenção de EPA e a aplicação da CCC como guia desse processo avançam a área em direção ao preenchimento de ambas as lacunas, complementando a literatura atual. Por isso, este artigo tem o objetivo de descrever o desenvolvimento e examinar a validade social de uma intervenção para preparação para aposentadoria baseada na $\mathrm{CCC}$, por meio de três implementações. Especificamente, o estudo visa a examinar a significância social das metas, a aceitabilidade social dos procedimentos e a importância social dos efeitos da intervenção.

\section{Método}

Este estudo examinou a validade social de uma intervenção de educação para a aposentadoria. Considerando o estágio de desenvolvimento da intervenção, foi realizado um estudo de casos múltiplos, delineamento que permite avaliar qualitativamente as características contextuais e técnicas que podem influenciar o funcionamento e o resultado da intervenção. 


\section{Delineamento e Participantes}

O delineamento utilizado para avaliar a intervenção foi o estudo de casos múltiplos. Esse delineamento permite analisar singularidades do fenômeno em questão, assim como os estudos de caso único, mas sua lógica de replicação favorece a produção de evidências geralmente mais robustas (Yin, 2013). Os casos analisados foram três grupos de EPA realizados com trabalhadores em transição para a aposentadoria oriundos de três contextos distintos na cidade de Brasília - DF, entre agosto e dezembro de 2015 .

O Caso 1 foi realizado em uma instituição pública federal com fins de gestão de políticas científicas. O Caso 2 foi realizado em uma instituição pública federal da área jurídica. Por fim, o Caso 3 foi realizado com trabalhadores identificados por meio da rede de contatos profissionais dos pesquisadores. Em todos os casos, o único critério de inclusão foi a manifestação de interesse em participar da intervenção, independente de idade ou tempo de serviço restante até a aposentadoria ou posterior à aposentadoria. A inclusão de participantes aposentados se justifica pela sua exposição a fatores de risco e prejuízos relativos ao ajustamento à aposentadoria, contemplando a prevenção indicada (Muñoz et al., 1996).

Ao todo, participaram do estudo 27 trabalhadores (22 mulheres e cinco homens), com idade entre 29 e 65 anos $(M=51)$. O Caso 1 foi realizado com 15 trabalhadores da instituição, sendo 13 mulheres e dois homens. O Caso 2 foi realizado com nove pessoas da instituição, sendo sete mulheres e dois homens; e o Caso 3 foi realizado com três participantes, sendo duas mulheres e um homem.

De acordo com o cronograma inicial, os grupos seriam realizados sequencialmente. Assim, os problemas identificados em cada caso indicariam mudanças a serem incluídas nos estudos posteriores. No entanto, em função da disponibilidade das 
instituições, o cronograma foi antecipado e houve sobreposição entre os períodos de implementação das intervenções.

\section{Instrumentos}

Questionário de levantamento de necessidades e avaliação de resultados. Essas informações foram coletadas por meio de questões abertas. No início da intervenção, os participantes registraram seu interesse em participar da intervenção e as expectativas de resultado. Para identificar os motivos para buscar a intervenção, os participantes completavam a frase "Procurei essa atividade porque..."; para avaliar suas expectativas, completavam a frase "Ao fim dessa atividade, eu espero..."; e, ao fim da intervenção, para indicar se as expectativas iniciais haviam sido atingidas, os participantes completavam a frase "Ao comparar minhas expectativas iniciais com os resultados que obtive nessa intervenção, penso que...”.

Questionário de áreas da vida. A seleção das áreas da vida a serem trabalhadas foi realizada por meio de uma versão do Valued Living Questionnaire (VLQ; Wilson, Sandoz, Kitchens, \& Roberts, 2010) traduzida para o português. O instrumento visa a avaliar o comprometimento com os valores pessoais, comparando a relevância e a dedicação em 10 áreas da vida. Ambos são avaliados a partir de uma escala entre 1 (completamente sem importância) e 10 (extremamente importante).

Matriz. Diagrama interativo desenvolvido por Polk e Schoendorff (2014) que visa a promover de flexibilidade psicológica e se baseia no modelo de saúde, psicopatologia e intervenção da terapia de aceitação e compromisso. O diagrama é formado pelo cruzamento de duas linhas perpendiculares que visam a organizar as experiências do indivíduo ou do grupo: uma linha horizontal separa estímulos e comportamentos internos (metade inferior) e externos (metade superior); e uma linha vertical separa os estímulos e comportamentos funcionais (metade direita) e disfuncionais (metade 
esquerda). O cruzamento das duas linhas em forma de cruz cria quatro quadrantes ou categorias: eventos internos aversivos, ações disfuncionais, valores e metas. Essa categorização permite identificar padrões de pensamentos, sentimentos e comportamentos, assim como favorece o planejamento de ações baseadas em valores.

Escala de percepção de satisfação. A satisfação com a intervenção foi mensurada por meio da avaliação de satisfação, instrumento desenvolvido pelos autores deste estudo. Em uma escala entre 1 (completamente insatisfatório) e 10 (completamente satisfatório), os participantes indicavam sua satisfação com facilitador, conteúdo, material e com a intervenção em geral. Além disso, também poderiam descrever os pontos positivos e negativos referentes a esses itens.

Tabela de ativação comportamental. Utilizada para promover a prática de novos comportamentos (Kanter, Busch, \& Rusch, 2009). A tabela contém cinco colunas, nas quais o participante descreve o comportamento, as contingências para sua realização, os obstáculos potenciais e as possíveis soluções para esses obstáculos.

Quadro de monitoramento de atividades. Este instrumento visa a identificar padrões comportamentais e suas frequências (Kanter et al., 2009). Trata-se de uma tabela com duas colunas, em que a primeira apresenta 10 áreas da vida (p. ex., saúde e vida social) e a segunda oferece espaço para que o participante registre diariamente as atividades que realizou em cada área da vida.

\section{Materiais para a Intervenção}

Preditores de ajustamento. Conjunto de variáveis que predizem um bom ajustamento à aposentadoria (Barbosa et al., 2016). Apenas os preditores com embasamento empírico amplo e evidências de efeito positivo foram apresentados e discutidos: saúde física e psicológica, finanças, lazer, opção voluntária pela aposentadoria, interação social, preparação para a aposentadoria, relacionamento conjugal, trabalho pós- 
aposentadoria, condições de trabalho antes da aposentadoria, espiritualidade, duração da aposentadoria, parentalidade e educação.

Lista de valores. Relação de valores extraída do instrumento Survey of Guiding Principles (SGP; Ciarrochi \& Bailey, 2008). A lista apresenta expressões que os participantes podem selecionar ou adaptar para identificar seus próprios valores, incluindo características bastante diversas, como conexão com a natureza, honestidade, ajudar os outros, ser leal, ter relações amorosas, praticar esportes e comer saudavelmente, por exemplo.

\section{Procedimentos}

A intervenção foi desenvolvida a partir de intervenções sobre EPA descritas na literatura (Leandro-França et al., 2016; Murta et al., 2014). O planejamento inicial previa a realização de quatro encontros com 3 h de duração, semanalmente. No entanto, os encontros do Caso 1 foram realizados mensalmente, a pedido da coordenadora da instituição. No Caso 2, os encontros tiveram frequência semanal e duração de $2 \mathrm{~h}$, incluindo-se mais um encontro, totalizando cinco. Por fim, no Caso 3, a frequência semanal foi mantida, a duração foi reduzida para 1 h30 e o número de encontros foi elevado para sete. A Tabela 1 mostra a evolução da estrutura dos casos.

Tabela 1

Evolução da estrutura dos casos

\begin{tabular}{lcccc}
\hline & $\begin{array}{c}\text { Total de } \\
\text { encontros }\end{array}$ & Periodicidade & $\begin{array}{c}\text { Duração do } \\
\text { encontro }\end{array}$ & $\begin{array}{c}\text { Formato do } \\
\text { grupo }\end{array}$ \\
\hline Caso 1 & 4 & mensal & $3 \mathrm{~h}$ & aberto \\
Caso 2 & 5 & semanal & $2 \mathrm{~h}$ & fechado \\
Caso 3 & 7 & semanal & $1 \mathrm{~h} 30$ & fechado \\
\hline
\end{tabular}

O conteúdo dos encontros está descrito na Tabela 2, de acordo com sua implementação em cada caso. Os procedimentos realizados nos três casos foram semelhantes, incluindo atividades informativas, como a apresentação dos preditores de ajustamento à aposentadoria e do modelo prossocial, e atividades experienciais, como as 
discussões sobre áreas da vida escolhidas pelos participantes, valores e eventos internos aversivos. O número de áreas da vida trabalhadas em cada caso, no entanto, variou de acordo com o número de encontros: no Caso 1, abordaram-se duas áreas da vida; no Caso 2, abordaram-se três áreas; e no Caso 3, abordaram-se cinco áreas. A única variação de conteúdo foi a implementação completa do modelo prossocial (identidade comum e propósitos claros, monitoramento, tomada de decisão coletiva) no Caso 3. Nos Casos 1 e 2, imprevistos ocorridos após o primeiro encontro levaram à suspensão da implementação dos outros dois princípios.

Tabela 2

Conteúdo dos encontros

\begin{tabular}{|c|c|c|}
\hline Encontro & Atividade & Caso \\
\hline 1 & $\begin{array}{l}\text { - } \text { Apresentação da intervenção } \\
\text { - } \quad \text { Preditores de ajustamento à aposentadoria } \\
\text { - } \text { Apresentação do Prossocial } \\
\text { - } \quad \text { Princípio } 1 \text { do Prossocial, Identidade } \\
\text { - Apresentação da Matriz } \\
\text { - Lista de valores } \\
\text { - Tarefa: Tabela de monitoramento } \\
\text { - Avaliação do encontro }\end{array}$ & $\begin{array}{l}1,2 \text { e } 3 \\
1,2 \text { e } 3 \\
1,2 \text { e } 3 \\
1,2 \text { e } 3 \\
1,2 \text { e } 3 \\
1,2 \text { e } 3 \\
1,2 \text { e } 3 \\
1,2 \text { e } 3\end{array}$ \\
\hline 2 & $\begin{array}{l}\text { - } \quad \text { Resultados da avaliação do encontro anterior } \\
\text { - VLQ para identificar } 3 \text { áreas da vida a trabalhar } \\
\text { - Matriz - área da vida \#1 } \\
\text { - Princípio } 2 \text { do Prossocial, Monitoramento } \\
\text { - Tarefa: Tabela de ativação } \\
\text { - Tarefa: Descrição da importância da área da vida \#1 } \\
\text { - Avaliação do encontro }\end{array}$ & $\begin{array}{l}1,2 \text { e } 3 \\
1,2 \text { e } 3 \\
1,2 \text { e } 3 \\
3 \\
1,2 \text { e } 3 \\
1,2 \text { e } 3 \\
1,2 \text { e } 3\end{array}$ \\
\hline 3 & $\begin{array}{l}\text { - Resultados da avaliação do encontro anterior } \\
\text { - Revisão das tarefas } \\
\text { - Matriz da área da vida \#2 } \\
\text { - Princípio } 2 \text { do Prossocial, Decisão colaborativa } \\
\text { - Tarefa: Tabela de ativação } \\
\text { - Tarefa: Descrição da importância da área da vida \#2 } \\
\text { - Avaliação do encontro }\end{array}$ & $\begin{array}{l}1,2 \text { e } 3 \\
1,2 \text { e } 3 \\
1,2 \text { e } 3 \\
3 \\
1,2 \text { e } 3 \\
1,2 \text { e } 3 \\
1,2 \text { e } 3\end{array}$ \\
\hline 4 & $\begin{array}{l}\text { - Resultados da avaliação do encontro anterior } \\
\text { - Revisão das tarefas } \\
\text { - Matriz - área da vida \#3 } \\
\text { - Tarefa: Tabela de ativação } \\
\text { - Tarefa: Descrição da importância da área da vida \#3 } \\
\text { - Avaliação do encontro }\end{array}$ & $\begin{array}{l}2 \text { e } 3 \\
2 \text { e } 3 \\
2 \text { e } 3 \\
2 \text { e } 3 \\
2 \text { e } 3 \\
2 \text { e } 3\end{array}$ \\
\hline 5 & $\begin{array}{l}\text { - Resultados da avaliação do encontro anterior } \\
\text { - Revisão das tarefas } \\
\text { - Matriz da área da vida \#4 }\end{array}$ & $\begin{array}{l}3 \\
3 \\
3\end{array}$ \\
\hline
\end{tabular}


- Tarefa: Tabela de ativação 3

- Tarefa: Descrição da importância da área da vida \#4 3

- Avaliação do encontro 3

- Resultados da avaliação do encontro anterior 3

- Revisão das tarefas 3

- Matriz da área da vida \#5 3

6

- Tarefa: Tabela de ativação 3

- Tarefa: Descrição da importância da área da vida \#5 3

- Tarefa: Plano individual para a aposentadoria 3

- Avaliação do encontro 3

- Resultados da avaliação do encontro anterior 1,2 e 3

7 - Revisão das tarefas 1,2 e 3

- Próximos passos 1, 2 e 3

- Avaliação da intervenção 1,2 e 3

\section{Análise dos Dados}

A análise dos dados considerou a singularidade de cada caso, a variabilidade de contextos e grupos, e suas contribuições relativas para a compreensão das evidências de validade social das metas, procedimentos e efeitos. Por isso, cada caso será analisado em relação a um componente da validade social cuja contribuição se destaca no desenvolvimento da intervenção. Os dados textuais foram analisados independentemente por dois juízes de acordo com o procedimento sugerido por Braun e Clarke (2006). Primeiro as respostas dos participantes foram lidas diversas vezes e separadas em unidades básicas de análise, cada uma contendo apenas uma característica positiva ou negativa. Cada unidade foi classificada de acordo com o tema expresso e os temas foram organizados em categorias mais abrangentes. Então essas categorias foram comparadas aos dados originais e as discrepâncias constatadas levaram ao refinamento das categorias temáticas finais. Os dados quantitativos foram computados e analisados por meio de duas estatísticas descritivas, frequência e média.

O Caso 1 analisa a significância social das metas, baseando-se no uso da Matriz. Essa análise foi realizada por meio dos critérios propostos por Lane e BeebeFrankenberger (2004), que abrangem preferências e valores do consumidor, promoção de habilidades comuns entre pares e relevantes em diferentes contextos, possibilidade 
de escolher metas de interesse pessoal e possibilidade de aproveitar habilidades prévias ou adaptar aspectos do tratamento. Os relatos dos participantes foram organizados de acordo com esses cinco critérios, então indicando se cada critério foi atendido. O Caso 2 analisa a aceitabilidade social dos procedimentos por meio dos relatos e escores de satisfação coletados ao final de cada encontro por meio da Escala de Percepção de Satisfação. Os relatos de satisfação obtidos para cada item (facilitador, material, conteúdo e geral) foram interpretados a partir da identificação dos temas mencionados e da sua frequência (Yin, 2013). Os escores de satisfação obtidos para cada item foram agrupados por encontro e apresentados em valores médios para cada categoria. O Caso 3 analisa a importância social dos efeitos por meio do comprometimento com as metas e de uma avaliação final sobre os resultados. $\mathrm{O}$ comprometimento foi avaliado por meio da revisão semanal das metas, comparando o desempenho do participante à meta estabelecida no encontro anterior. A avaliação final sobre os resultados foi analisada em contraste com os relatos das expectativas iniciais (Yin, 2013), revelando se a intervenção satisfez as expectativas.

\section{Resultados e Discussão}

\section{Caso 1}

O Caso 1 consistiu na primeira implementação da intervenção. A intervenção permaneceu aberta à entrada de novos participantes, sendo 15 no total e cerca de nove por encontro.

Para avaliação da significância social das metas, serão apresentados os resultados de duas atividades realizadas no Encontro 3: revisão de tarefas e Matriz da área da vida número 2. A Figura 1 apresenta a Matriz construída pelo grupo, iniciada no Encontro 2 e finalizada no Encontro 3. No Encontro 2, o grupo escolheu o tema saúde e preencheu a Matriz, incluindo as metas a serem realizadas no intervalo entre os 
encontros. No Encontro 3, essa Matriz foi revista para registrar o compromisso com as atividades descritas no campo Metas, indicando as atividades que foram realizadas e as atividades que não foram realizadas. Para a realização desta técnica, são os próprios participantes que indicam a área da vida a ser abordada, os valores pessoais que dão sentido a essa área e as atividades compatíveis com esses valores que estão interessados em realizar. Isso confere aos participantes autonomia para individualizar sua preparação para a aposentadoria, desde as áreas da vida que lhe interessam até a escolha das metas e suas condições de execução.

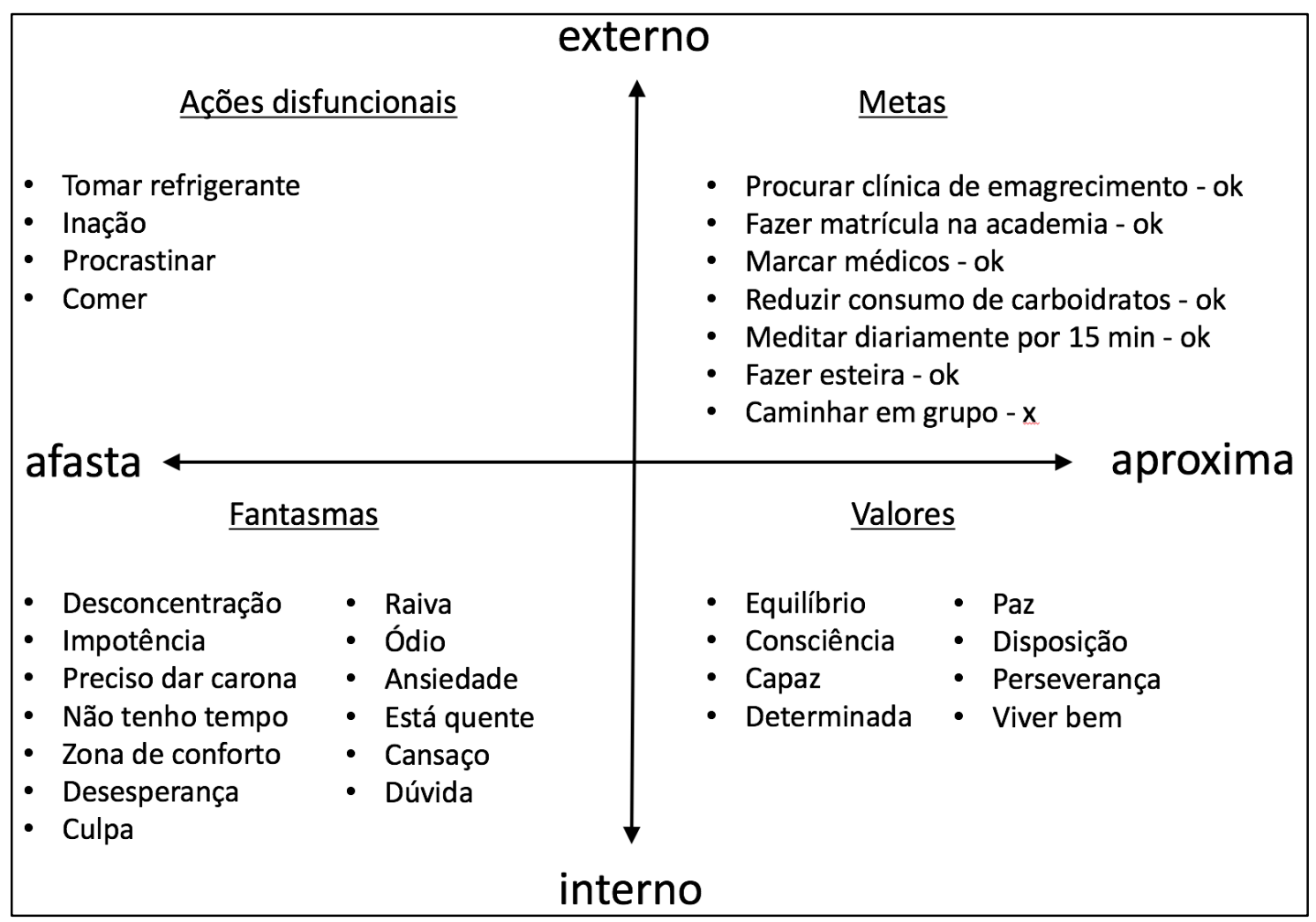

Figura 1. Matriz construída pelo grupo sobre o tema saúde.

A Figura 2 apresenta a Matriz da área da vida preenchida no Encontro 3. Desta vez, os participantes manifestaram interesses distintos e optaram por se dedicar a diferentes áreas da vida: carreira, educação, cidadania e espiritualidade. Essa possibilidade mostra que a Matriz favorece tanto a autonomia, importante para a individualização da intervenção de acordo com necessidades e interesses pessoais, como 
a cooperação, pois os participantes se influenciam mutuamente. Mesmo abordando áreas da vida distintas, os participantes repetiam alguns dos valores, fantasmas e ações disfuncionais relatados por outros participantes. E, na definição das metas, surgiu a oportunidade de trabalho conjunto: por exemplo, na Figura 2, caminhar em ambiente fechado foi negociada entre quatro participantes, que planejavam fazer essa atividade juntos, no horário de almoço, no terreno da instituição. Já a atividade caminhar em grupo foi negociada por duas participantes que moram próximas e planejavam se exercitar antes do trabalho.

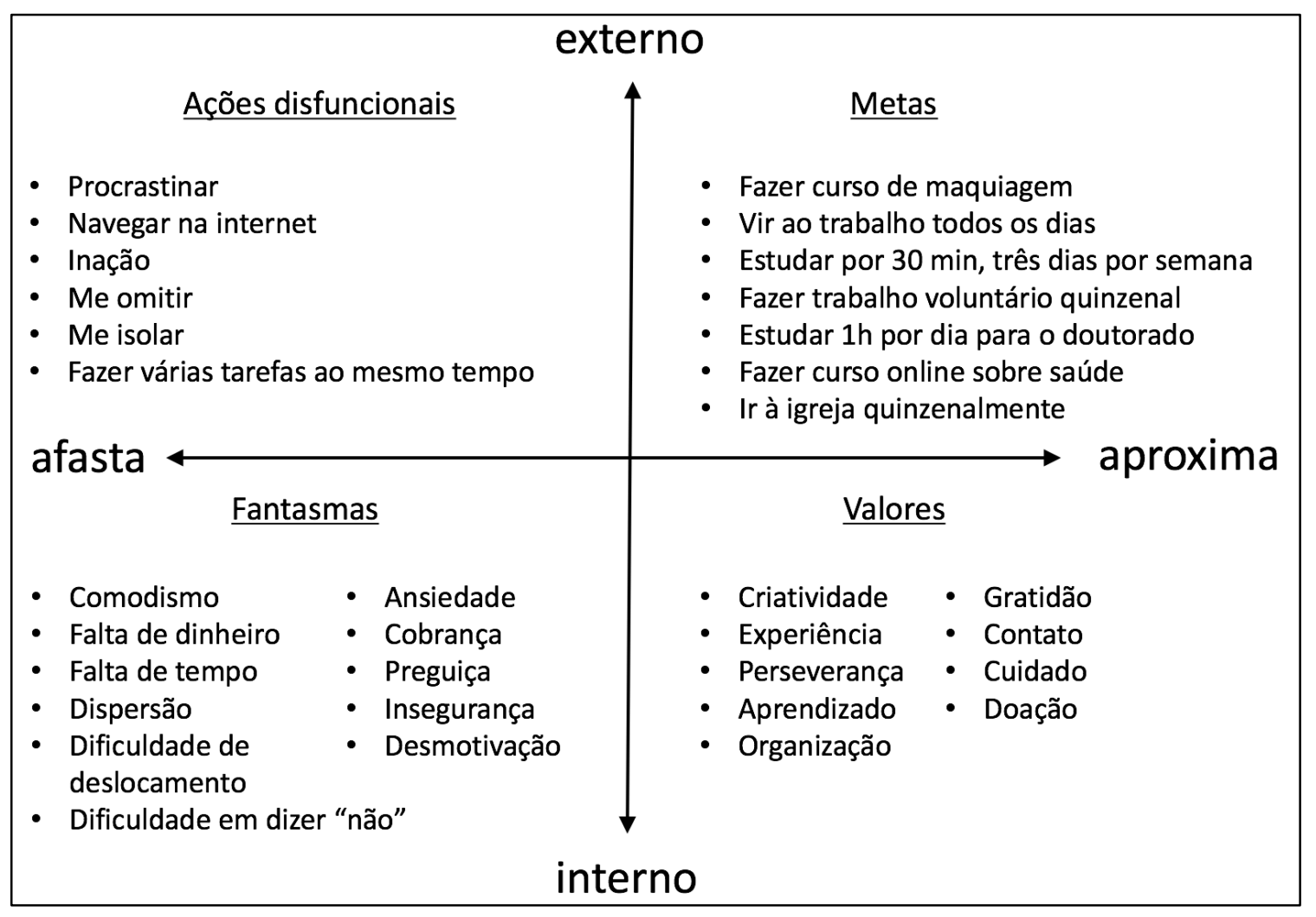

Figura 2. Matriz sobre assuntos diversos.

Os resultados das duas atividades que utilizaram a Matriz mostram que as metas da intervenção têm alta significância social. A possibilidade de individualizar a participação pessoal e de se beneficiar com o trabalho do grupo mostra que esta intervenção tem o potencial de atender às categorias apresentadas no Checklist de Lane e Beebe-Frankenberger (2004), contemplando habilidades prévias dos participantes; 
adaptando a intervenção a suas preferências, valores e metas; e promovendo habilidades relevantes em diferentes situações. Isso reitera a importância do desenvolvimento de intervenções bem fundamentadas filosófica e teoricamente, um dos princípios da CCC: a Matriz foi desenvolvida com o objetivo de promover flexibilidade psicológica, construto que contempla as dimensões apontadas na literatura (Lane \& BeebeFrankenberger, 2004).

\section{Caso 2}

O Caso 2 consistiu na segunda implementação da intervenção. A partir da experiência do Caso 1, esta intervenção foi realizada com um grupo fechado, iniciando com nove participantes, dos quais dois desistiram ao longo dos encontros. A pedido da coordenadora de recursos humanos do órgão, a intervenção foi ampliada para cinco encontros.

Para avaliar a aceitabilidade social dos procedimentos, apresentaremos os resultados da análise das avaliações qualitativas e quantitativas de satisfação realizadas ao fim dos encontros do Caso 2. A Tabela 3 mostra as categorias de aspectos positivos e negativos relatadas pelos participantes, assim como a satisfação média com cada item da intervenção.

Tabela 3

Avaliações qualitativas e quantitativas da satisfação com os encontros

\begin{tabular}{|c|c|c|c|c|c|}
\hline & \multicolumn{2}{|c|}{ Aspectos positivos } & \multicolumn{2}{|l|}{ Aspectos negativos } & \multirow[t]{2}{*}{$\begin{array}{c}\text { Satisfação } \\
\text { média }\end{array}$} \\
\hline & Categoria & $\mathbf{n}$ & Categoria & $\bar{n}$ & \\
\hline \multirow{4}{*}{ Facilitador } & Assertividade & 13 & Condução inadequada & 4 & \multirow{4}{*}{9,2} \\
\hline & Flexibilidade & 13 & Falta de clareza & 2 & \\
\hline & $\begin{array}{l}\text { Atenção ao } \\
\text { presente }\end{array}$ & 8 & Tempo insuficiente & 2 & \\
\hline & Satisfatório & 3 & & & \\
\hline \multirow{4}{*}{$\begin{array}{c}\text { Conteúdo e } \\
\text { procedimentos }\end{array}$} & Produtivo & 8 & Didática inadequada & 4 & \multirow{4}{*}{9} \\
\hline & Clareza & 6 & Tempo insuficiente & 4 & \\
\hline & Satisfatório & 3 & Falta de interação social & 1 & \\
\hline & Sob medida & 2 & & & \\
\hline \multirow{2}{*}{ Material } & Satisfatório & 10 & Aprimorar o material & 5 & \multirow{2}{*}{9} \\
\hline & Didático & 7 & Baixa integridade & 2 & \\
\hline
\end{tabular}




\begin{tabular}{llllll}
\hline & Responsivo & 2 & & \\
\hline \multirow{3}{*}{ Geral } & Satisfatório & 8 & Falta de interação social & 3 & \\
& Benefício pessoal & 5 & Procedimentos inadequados & 3 & 9,2 \\
& Interação social & 4 & Questões pessoais & 3 & \\
\hline
\end{tabular}

Nos comentários positivos sobre o Facilitador, os participantes mencionaram 37 características, que foram classificadas em quatro categorias: assertividade $(n=13 ; \mathrm{p}$. ex., “objetivo"); flexibilidade (n = 13; p. ex., "aberto para ouvir"); atenção ao presente (n = 8; p. ex., "conectado com o grupo") e satisfatório (n=3; p. ex., "gostei”). Nos comentários negativos, os participantes mencionaram oito características, que foram classificadas em três categorias: condução inadequada $(n=4$; p. ex., "estou achando o ritmo acelerado"), tempo insuficiente ( $\mathrm{n}=2$; p. ex., "pouco tempo") e falta de clareza (n $=2$; p. ex., "às vezes não compreendo onde a atividade vai dar").

Nos comentários positivos sobre Conteúdo e Procedimentos, os participantes mencionaram 19 características, que foram classificadas em quatro categorias: produtivo (n = 8; p. ex., "permitiu uma introspecção"), clareza (n = 6; p. ex., "realçou o objetivo do programa"), satisfatório ( $\mathrm{n}=3$; p. ex., "adequado"), sob medida ( $\mathrm{n}=2 ; \mathrm{p}$. ex., "focado no ritmo do grupo"). Nos comentários negativos, os participantes mencionaram nove características, que foram agrupadas em três categorias: didática inadequada ( $\mathrm{n}=4$; p. ex., "ter mais exemplos práticos"), tempo insuficiente $(\mathrm{n}=4$; “ficou prejudicado pelo pouco tempo") e baixa interação social (n = 1; "os colegas ausentes poderiam ter acrescentado bastante").

Nos comentários positivos sobre o Material, os participantes mencionaram 19 características, que foram classificadas em três categorias: satisfatório $(n=10 ; p$. ex., “gostei”), didática ( $\mathrm{n}=7$; p. ex., "didático") e responsividade $(\mathrm{n}=2$; “minha queixa anterior já foi atendida"). Nos comentários negativos, os participantes mencionaram sete características, que foram agrupadas em duas categorias: aprimorar o material $(\mathrm{n}=$ 
5; p. ex., "a falta de numeração atrapalha o manuseio do material durante o encontro") e baixa integridade ( $\mathrm{n}=2$; p. ex., "queria ver mais do que o facilitador trouxe").

Nos comentários positivos da avaliação em Geral, os participantes mencionaram 17 características, que foram classificadas em três categorias: satisfatório $(n=7$; p. ex., “muito bom"), benefício pessoal ( $\mathrm{n}=4$; "fiquei feliz por ter elencado as sugestões e respondido") e interação social ( $\mathrm{n}=2$; "muito bom o trabalho em grupo"). Nos comentários negativos, os participantes mencionaram nove características, que foram agrupadas em três categorias: falta de interação social $(n=3$; p. ex., "muitas pessoas ausentes"), procedimentos gerais ( $\mathrm{n}=3$; p. ex., “equilibrar a parte expositiva") e questões pessoais ( $n=3$; p. ex., "estou em um momento de vida de foco na sombra"). No total, houve 88 comentários positivos e 33 comentários negativos.

A relevância atribuída à atuação do facilitador é compatível com evidências sobre implementação de intervenções (Berkel, Mauricio, Schoenfelder, \& Sandler, 2011; Santos \& Murta, 2015), que indicam a influência do comportamento do facilitador sobre o desfecho da intervenção. Também é importante que o conteúdo favoreça reflexões pessoais significativas e que o material seja organizado, diversificado e didático. Para aprimorar a validade da intervenção, no entanto, é necessário resolver duas importantes deficiências: didática inadequada e adequação do conteúdo ao tempo. Em parte, a didática pode ser melhorada pelo uso de métodos dinâmicos, como vídeos ou exercícios experienciais; adequação do material, inserindo sumário e numeração de página; e pela apresentação clara do conteúdo e dos objetivos das atividades. No entanto, parte da didática depende da adequação do conteúdo ao tempo disponível. Problemas como exposição parcial do material escrito ou visual e poucas oportunidades de discussão entre os participantes resultaram da insuficiência do tempo. 
Também é importante destacar outros procedimentos que se mostraram inadequados. Primeiro, no Caso 1, a intervenção permaneceu aberta para a entrada de novos participantes em todos os encontros. Por isso, foi necessário reapresentar a intervenção a cada encontro, dificultando a consolidação do grupo e a continuidade do trabalho. Para evitar esse problema, as intervenções posteriores foram realizadas com grupos definidos nos primeiros encontros. Segundo, nos Casos 1 e 2, a intervenção aconteceu no ambiente de trabalho dos participantes. Aparentemente a realização de demandas profissionais no horário da intervenção favoreceu a ocorrência de faltas. Por outro lado, a realização da intervenção na própria instituição favorece o acesso dos participantes. Essa característica parece mais uma condição a ser observada do que um problema a ser resolvido. Terceiro, no Caso 2, a coordenadora divulgou a intervenção apenas aos colegas que já haviam participado de outros programas de qualidade de vida, incluindo uma intervenção de longa duração de preparação para a aposentadoria. Para evitar esse problema, o recrutamento deve ser realizado pelo pesquisador ou planejado em conjunto com o responsável institucional.

\section{Caso 3}

O Caso 3 apresenta a última implementação da intervenção, realizada com três participantes selecionados por conveniência. Para favorecer a abordagem de mais áreas da vida, foram acrescentados mais dois encontros, totalizando sete. E, para evitar uma grande variação na carga-horária, a duração de cada encontro foi reduzida para 1h30m. Assim, enquanto o Caso 2 teve carga-horária de 10h, com cinco encontros de $2 \mathrm{~h}$, a carga-horária do Caso 3 foi de 10h30m, com sete encontros de $1 \mathrm{~h} 30 \mathrm{~m}$.

Para avaliar a importância social dos efeitos, apresentaremos os efeitos comportamentais resultantes dos encontros do Caso 3. A Tabela 3 apresenta os comportamentos de cada participante durante a primeira semana da intervenção, antes 
do início das atividades para promoção de novos comportamentos. Além da prática regular de atividade física, os participantes apresentaram padrões distintos de quantidade e variedade de atividades. Embora a participante 1 esteja aposentada da sua primeira carreira (médica), ela desempenha regularmente atividades na sua carreira pósaposentadoria (professora). Observa-se também que a participante 3 não realizou atividades com amigos e que todas as suas atividades de lazer são solitárias. Foram apresentadas apenas as atividades nas áreas que os participantes abordaram durante a intervenção. Por isso, as atividades nas áreas Amizades (participantes 1 e 2) e Relacionamento íntimo (participante 3) foram omitidas. Na Tabela 4, são apresentadas apenas as atividades relativas às áreas da vida trabalhadas durante a intervenção.

Tabela 4

Tipo e frequência de atividades durante a primeira semana

\begin{tabular}{|c|c|c|c|}
\hline $\begin{array}{l}\text { Área da } \\
\text { vida }\end{array}$ & P1 & P2 & P3 \\
\hline Saúde & $\begin{array}{l}\text { - Fisioterapia }\left(5^{*}\right) \\
\text { - Exercício (6) } \\
\text { - Meditação (6) } \\
\text { - Alimentação saudável }\end{array}$ & $\begin{array}{l}\text { - Exercício (6) } \\
\text { - Medicamentos (7) }\end{array}$ & $\begin{array}{l}\text { - Exercício } \\
\text { - Fisioterapia (3) }\end{array}$ \\
\hline Carreira & $\begin{array}{l}\text { - Aula de ioga (2) } \\
\text { - Estudos sobre ioga (3) } \\
\text { - Curso de mantras } \\
\end{array}$ & - Atividades regulares (6) & $\begin{array}{l}\text { - } \text { Atividades } \\
\text { regulares (5) }\end{array}$ \\
\hline Lazer & $\begin{array}{l}\text { - Café da manhã na padaria } \\
\text { - Leitura (4) } \\
\text { - Música } \\
\text { - Piscina (2) } \\
\text { - Sauna } \\
\text { - Jornal (2) } \\
\text { - Tarde com toda a família } \\
\text { - TV (2) } \\
\text { - Tocar gongo } \\
\text { - Cinema } \\
\text { - Almoço com parentes } \\
\text { - Cuidar do jardim }\end{array}$ & $\begin{array}{l}\text { - Ouvir rádio no carro (2) } \\
\text { - Conversa com filho } \\
\text { - Pedalar com o filho } \\
\text { - Supermercado } \\
\text { - TV } \\
\text { - Visita a parentes } \\
\text { - Assistir jogo de basquete } \\
\text { do filho (3) }\end{array}$ & $\begin{array}{l}\text { - TV (5) } \\
\text { - Compras } \\
\text { - Almoço } \\
\text { - Jantar } \\
\text { - Shopping } \\
\text { - Viagem }\end{array}$ \\
\hline Amizades & N/A & N/A & --- \\
\hline $\begin{array}{l}\text { Relação } \\
\text { íntima }\end{array}$ & $\begin{array}{l}\text { - Café da manhã } \\
\text { - Almoço (2) } \\
\text { - } \mathrm{AF} \\
\text { - Shopping } \\
\text { - Tarde com filhas } \\
\text { - Diálogo durante a refeição }\end{array}$ & $\begin{array}{l}\text { - Diálogo durante as } \\
\text { refeições (5) } \\
\text { - Assistir jogo de basquete } \\
\text { do filho } \\
\text { - Organizar a sala } \\
\text { - Visita a parentes }\end{array}$ & N/A \\
\hline
\end{tabular}


* Os números entre parênteses indicam o número de dias em que o participante realizou a atividade. As atividades sem esta indicação foram realizadas apenas uma vez.

As Tabelas 5, 6 e 7 apresentam as expectativas, efeitos e avaliação dos efeitos da intervenção, por participante. Na seção Expectativas iniciais, constam o motivo pelo qual os participantes procuraram a intervenção e o que esperavam alcançar ao seu fimambas as respostas informadas no início do primeiro encontro. Na seção Mudanças comportamentais, as colunas numeradas indicam o intervalo entre o encontro em que os participantes estabeleceram as metas e o encontro em que checaram seu cumprimento. E, na seção Avaliação final, respondida no último encontro, consta a avaliação dos participantes sobre os efeitos da intervenção.

Tabela 5

Novos comportamentos, expectativas e avaliação da Participante 1

\begin{tabular}{|c|c|c|c|c|c|c|}
\hline \multirow{2}{*}{ Atividade } & \multicolumn{6}{|c|}{ Tema do encontro } \\
\hline & $\begin{array}{c}1-2 \\
\text { abertura }\end{array}$ & $\begin{array}{c}2-3 \\
\text { saúde }\end{array}$ & $\begin{array}{c}3-4 \\
\text { carreira }\end{array}$ & $\begin{array}{c}\text { 4-5 } \\
\text { lazer }\end{array}$ & $\begin{array}{c}5-6 \\
\text { carreira }\end{array}$ & $\begin{array}{c}\text { 6-7 } \\
\text { casal }\end{array}$ \\
\hline $\begin{array}{lr}\text { Diário } & \text { de } \\
\text { comportamentos } & \text { nas } \\
\text { áreas da vida } & \\
\end{array}$ & $\operatorname{sim}$ & & & & & \\
\hline $\begin{array}{l}\text { Meditar } 5 \text { dias na } \\
\text { semana, às } 5 \mathrm{~h}\end{array}$ & & $\operatorname{sim}$ & $<^{1}$ & $\operatorname{sim}$ & $\operatorname{sim}$ & $\operatorname{sim}$ \\
\hline $\begin{array}{l}\text { Ligar para colegas } \\
\text { médica e psicóloga }\end{array}$ & & & $>^{2}$ & & & \\
\hline $\begin{array}{ll}\text { Conversar } & \text { com } \\
\text { marido sobre lazer } \\
\text { conjunto }\end{array}$ & & & & não & & \\
\hline $\begin{array}{l}\text { Ler um tópico do } \\
\text { seminário }\end{array}$ & & & & & $\operatorname{sim}$ & \\
\hline $\begin{array}{l}\text { Desligar-se de alguns } \\
\text { projetos profissionais }\end{array}$ & & & & & $\operatorname{sim}$ & \\
\hline
\end{tabular}

\section{Expectativas Iniciais}

\begin{tabular}{ll}
\hline \multicolumn{1}{c}{ Questão } & \multicolumn{1}{c}{ Resposta do participante } \\
\hline $\begin{array}{l}\text { Por que } \\
\text { procurei essa } \\
\text { atividade? }\end{array}$ & $\begin{array}{l}\text { Preciso de mais foco, mais realidade, mais "chão" e me instrumentalizar } \\
\text { melhor em relação ao tempo; oportunidade de conversar, trabalhar, ordenar e } \\
\text { operacionalizar o que quero fazer daqui para a frente; conversar e lidar com } \\
\text { o medo do novo e diferente caminho. }\end{array}$ \\
\hline $\begin{array}{l}\text { O que espero } \\
\text { conseguir ao }\end{array}$ & $\begin{array}{l}\text { Ter colocado mais ordem e prioridade no que quero fazer; ter diretrizes do } \\
\text { como farei o que quero fazer; ter adquirido alguma "capacitação" ou }\end{array}$ \\
fim dessa & $\begin{array}{l}\text { instrumentos para lidar com a insegurança e medo - que isto não me } \\
\text { atividade? }\end{array}$ \\
\hline
\end{tabular}

Avaliação Final

\section{Questão}

Resposta do participante 


\begin{tabular}{ll}
\hline Ao comparar & Vi realmente a necessidade de priorizar e iniciei o processo de seleção de \\
minhas & prioridades entre os cursos que fiz e nas áreas em que posso atuar. Conheci \\
expectativas e & um instrumento - Matriz - que me ajudará a caminhar neste processo. \\
meus & Aprendi a importância do grupo (qualquer tipo de grupo) no meu projeto \\
resultados, & pessoal. Projeto pessoal não significa isolamento nem que será efetivado me \\
penso que: & isolando.
\end{tabular}

${ }^{1}$ Meditou 4 dias na semana; ${ }^{2}$ Também fez inscrição em congresso sobre luto.

A Tabela 5 mostra que, à exceção da meditação diária, todas as metas da Participante 1 envolviam comportamentos novos (não realizados na primeira semana da intervenção). No intervalo entre os Encontros 3 e 4, superou a meta profissional: além de ligar para duas colegas que trabalham com o assunto que pretende trabalhar, também se inscreveu em um congresso da área. Entre as oito metas propostas, a participante descumpriu apenas uma meta: não conversou com o marido sobre lazer. No Encontro 6, emocionada, ela relatou que se sentia incapaz de agir em relação ao marido. Com a colaboração do grupo, ela manteve seu compromisso com a relação conjugal por meio de uma meta que se julgava apta a realizar: refletir sobre sua relação diariamente, por 10 min. Comparando-se as expectativas iniciais à avaliação final, observa-se que a participante alcançou seus objetivos: aprendeu a se organizar melhor, aprendeu uma técnica para conduzir sua preparação e compreendeu que o trabalho em grupo pode facilitar seu projeto pessoal.

Tabela 6

Novos comportamentos, expectativas e avaliação do Participante 2

\begin{tabular}{|c|c|c|c|c|c|c|}
\hline \multirow{2}{*}{ Atividade } & \multicolumn{6}{|c|}{ Tema do encontro } \\
\hline & $\begin{array}{c}1-2 \\
\text { abertura }\end{array}$ & $\begin{array}{c}2-3 \\
\text { saúde }\end{array}$ & $\begin{array}{c}3-4 \\
\text { carreira }\end{array}$ & $\begin{array}{c}4-5 \\
\text { lazer }\end{array}$ & $\begin{array}{c}\text { 5-6 } \\
\text { carreira }\end{array}$ & $\begin{array}{c}6-7 \\
\text { casal }\end{array}$ \\
\hline $\begin{array}{l}\text { Registro diário de } \\
\text { comportamentos }\end{array}$ & $\operatorname{sim}$ & & & & & $\operatorname{sim}$ \\
\hline $\begin{array}{l}\text { Comer até } 3 \text { fatias de } \\
\text { pão integral por dia }\end{array}$ & & $>^{1}$ & $\operatorname{sim}$ & $\operatorname{sim}$ & $\operatorname{sim}$ & $\operatorname{sim}$ \\
\hline $\begin{array}{l}\text { Tomar até } 2 \text { cafés por } \\
\text { dia }\end{array}$ & & $\operatorname{sim}$ & $\operatorname{sim}$ & $<^{2}$ & $\operatorname{sim}$ & $\operatorname{sim}$ \\
\hline $\begin{array}{l}\text { Listar } 5 \text { opções de } \\
\text { atividades profissionais } \\
\text { futuras }\end{array}$ & & & $>^{3}$ & & & $\operatorname{sim}$ \\
\hline $\begin{array}{l}\text { Fazer } 2 \text { atividades de } \\
\text { lazer com a esposa }\end{array}$ & & & & $>^{4,5}$ & & $\operatorname{sim}$ \\
\hline Estruturar $\mathrm{e}$ redigir & & & & & $\operatorname{sim}$ & $\operatorname{sim}$ \\
\hline
\end{tabular}




\begin{tabular}{ll}
\hline plano de negócios & \\
\hline $\begin{array}{l}\text { Cuidar do horário de } \\
\text { dormir do filho }\end{array}$ & $\operatorname{sim}$ \\
\hline
\end{tabular}

\begin{tabular}{ll}
\hline \multicolumn{1}{c}{ Expectativas Iniciais } \\
\hline \multicolumn{1}{c}{ Questão } & \multicolumn{1}{c}{ Resposta do participante } \\
\hline $\begin{array}{l}\text { Por que } \\
\text { procurei essa } \\
\text { atividade? }\end{array}$ & $\begin{array}{l}\text { Estou há 46 anos no serviço público; nunca atuei sem estar empregado; está } \\
\text { na hora de pensar o que fazer nos próximos anos. Não quero desperdiçar o } \\
\text { que aprendi. Sei ajudar pessoas e quero continuar. }\end{array}$ \\
\hline $\begin{array}{l}\text { O que espero } \\
\text { conseguir ao } \\
\text { fim dessa } \\
\text { atividade? }\end{array}$ & $\begin{array}{l}\text { Um plano para atividades a serem desenvolvidas como autônomo. Algumas } \\
\text { possibilidades de trabalho. Conhecer mais sobre a vida depois da }\end{array}$ \\
\hline
\end{tabular}

\begin{tabular}{|c|c|}
\hline \multicolumn{2}{|r|}{ Avaliação final } \\
\hline Questão & Resposta do participante \\
\hline $\begin{array}{l}\text { Ao comparar } \\
\text { minhas } \\
\text { expectativas e } \\
\text { meus } \\
\text { resultados, } \\
\text { penso que: }\end{array}$ & $\begin{array}{l}\text { Os resultados superaram em muito as expectativas. Aprendi com os colegas } \\
\text { do grupo a pensar, planejar e compartilhar as ideias sobre o futuro. Tenho } \\
\text { que ter metas desafiadoras, mas factíveis. Os encontros serviram para } \\
\text { reforçar a necessidade de planejar o futuro com base nos fatores psicológicos } \\
\text { e sociais (os preditores) que interferem no ajuste das pessoas, no meu ajuste, } \\
\text { quando me aposentar. }\end{array}$ \\
\hline
\end{tabular}

${ }^{1}$ Reduziu a meta para até duas fatias de pão integral por dia; ${ }^{2}$ Ultrapassou a meta em um dos dias; ${ }^{3}$ Listou 10 opções; ${ }^{4}$ Happy hour, 2 filmes no cinema, compras no mercado, preparar almoço, andar de bicicleta; ${ }^{5}$ Relatou outras mudanças iniciadas após o início da intervenção: lanche vespertino; reduziu alimentação noturna; emagreceu 4k; no trabalho, faz críticas mais amenas e age com mais calma.

A Tabela 6 mostra que o Participante 2 cumpriu todas as metas, que incluíam apenas comportamentos novos. Apenas no intervalo entre o Encontros 4 e 5 seu desempenho foi ligeiramente inferior ao planejado: por um dia, excedeu o limite diário de ingestão de café. Por outro lado, ao trabalhar as áreas saúde, profíssão e relação conjugal, ele superou as próprias metas: implementou quatro mudanças alimentares (ele reduziu a ingestão de café em "solidariedade" à Participante 3, que sugeriu essa meta), que resultaram no emagrecimento de $4 \mathrm{~kg}$ depois de um mês de intervenção; listou o dobro do número planejado de possibilidades profissionais futuras; passou a interagir com os colegas de trabalho com mais calma; e fez quatro atividades com a esposa, embora tivesse planejado apenas uma. Comparando-se as expectativas iniciais à avaliação final, observa-se que os efeitos atenderam suas expectativas: o participante discutiu em grupo a vida na aposentadoria, identificou possibilidades de atuação, 
escolheu uma possibilidade e iniciou a construção de um plano de negócios. Além disso, reconheceu a importância de se preparar para a aposentadoria e aprendeu a planejar metas mais produtivas.

Tabela 7

Novos comportamentos, expectativas e avaliação da Participante 3

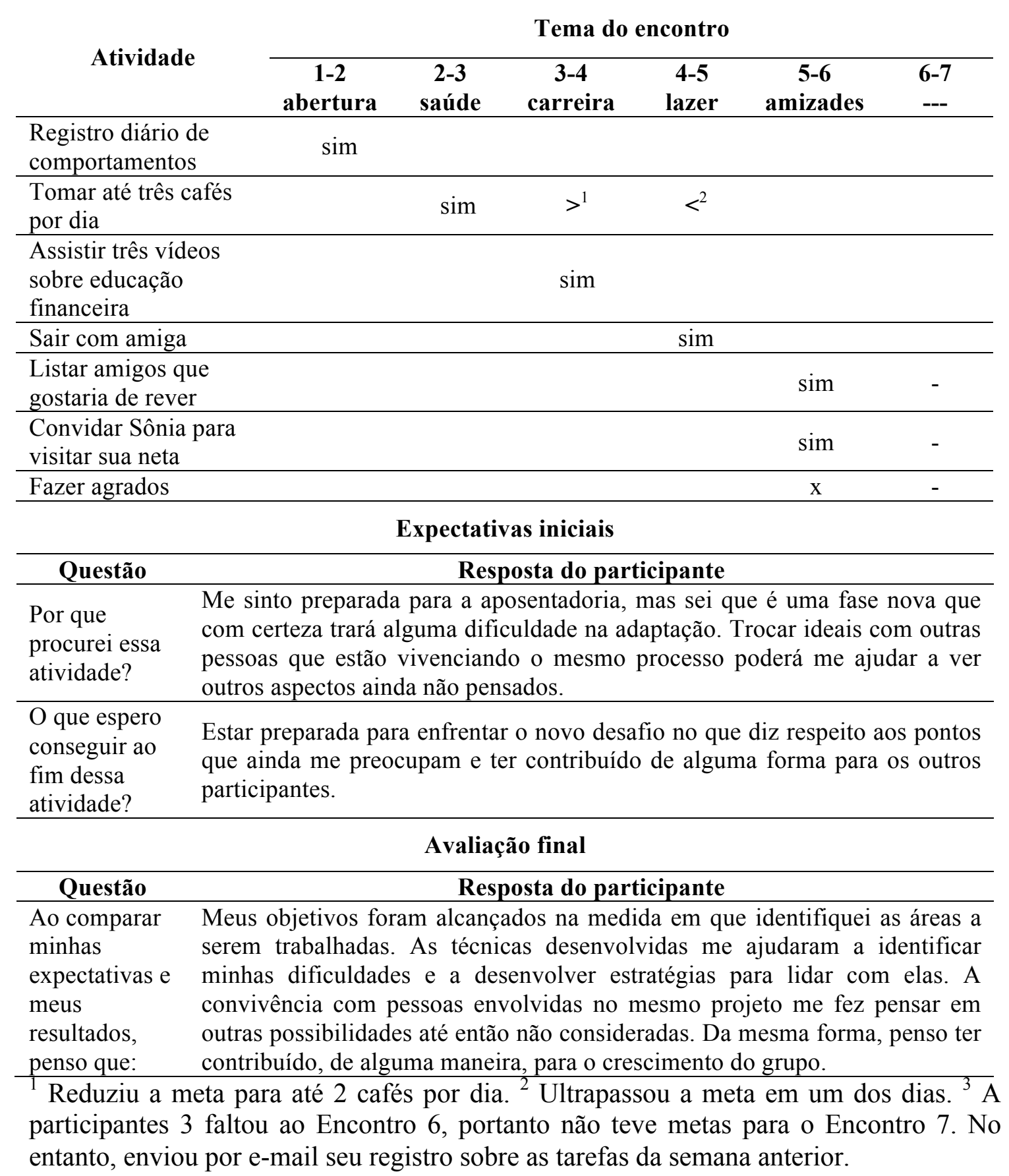


A Tabela 7 mostra que a Participante 3 cumpriu seis das metas propostas, sendo que todas incluíam comportamentos novos. No intervalo entre os Encontros 3 e 4, ingeriu menos café do que o planejado, mas na semana seguinte excedeu o limite diário em um dia. No intervalo entre os Encontros 5 e 6, propôs três metas e cumpriu duas. Comparando-se as expectativas iniciais à avaliação final, observa-se que os efeitos da intervenção atenderam suas demandas: a participante identificou áreas da vida de interesse e escolheu uma atividade para se dedicar na aposentadoria - uma sugestão do Participante 2. Além disso, dedicou-se à vida social, sua área de maior interesse, tanto na interação com os colegas de intervenção como na interação com amigos.

Também é importante destacar outras características que influenciaram a validade social da intervenção. Nos três casos, não houve dificuldades na adesão à Matriz. Tanto para o desenvolvimento das áreas da vida, quanto para a revisão de tarefas, a Matriz foi repetidamente utilizada sem queixas ou perda de adesão. Também nos três casos, o compartilhamento de valores, eventos internos aversivos e comportamentos disfuncionais ocorreu de maneira natural, crescendo ao longo da intervenção. Durante a atividade de estabelecer metas, houve situações em que os participantes ofereciam ou solicitavam sugestões aos pares.

O modelo prossocial foi pensado como um componente promotor da coesão e cooperação do grupo. O princípio de identificação de propósito e identidade comuns foi implementado em todos os casos, mas apenas no Caso 3 foram implementados os três princípios que compõem o modelo prossocial. Entre os resultados, o grupo do Caso 3 apresentou maior coesão, interação e ajuda mútua. Por exemplo, os participantes interagiam no intervalo entre os encontros, compartilhando a realização de metas por meio de mensagens de celular. No entanto, além da implementação completa do modelo prossocial, o Caso 3 também foi o único ocorrido fora do ambiente institucional, em 
horário complementar ao turno de trabalho e com participantes recrutados por meio da rede de contatos dos pesquisadores. Além disso, a não-realização de follow-up não permite avaliar a manutenção dos novos comportamentos, um dos efeitos esperados do aumento da cooperação entre os membros do grupo. Assim, não foi possível identificar o efeito diferencial do modelo prossocial.

\section{Conclusão}

O estudo de casos múltiplos descrito nesta pesquisafoi realizado com o objetivo de examinar a validade social de uma intervenção para EPA baseada na CCC. A intervenção apresentou metas socialmente relevantes, estimulando os participantes a escolherem metas de interesse pessoal e permitindo adaptar aspectos da intervenção, atendendo suas preferências e valores; as metas valorizavam habilidades prévias e promoviam novas habilidades comuns entre pares e relevantes para o desempenho em diferentes contextos. Boa parte dessas características pode ser atribuída à Matriz, que promove a identificação de valores e o compromisso com as metas pessoais. O cuidado com a significância social das metas tem relevância especial porque é a dimensão da validade social menos pesquisada (Fawcett, 1991).

Os procedimentos utilizados, em geral, foram bem recebidos, com destaque para a importância do papel do facilitador. A literatura mostra que este é um fator terapêutico importante (Budd \& Hughes, 2009) e poderia aprimorar a qualidade dos serviços em saúde mental (Laska, Gurman, \& Wampold, 2014). No entanto, ainda são necessários ajustes operacionais, como aprimorar o recrutamento, adequar o conteúdo à cargahorária e usar métodos mais dinâmicos.

Por fim, a intervenção promoveu efeitos socialmente importantes por meio de mudanças comportamentais sequenciais, de acordo com a área trabalhada, e compatíveis com as expectativas iniciais dos participantes. Esse resultado reforça o 
potencial das intervenções para EPA (Leandro-França et al., 2016), embora derive de uma intervenção baseada em teoria e procedimentos distintos. Os participantes tiveram metas bastante diversas e, algumas vezes, abordaram áreas da vida distintas em um mesmo encontro. No entanto, o foco em valores apresentou um eixo comum, favorecendo o trabalho em grupo e permitindo o desenvolvimento de interesses distintos.

Este estudo oferece três contribuições principais. A primeira se refere à aplicação da CCC como guia para o desenvolvimento de intervenções (Hayes et al., 2013). A construção da intervenção a partir de premissas filosóficas, teorias e métodos compatíveis com a CCC mostra a integração entre pressupostos e aplicação. A promoção do comprometimento com valores, levando a novos comportamentos protetivos, mostra a ênfase da intervenção em processos funcionais e manipuláveis. A simplicidade da intervenção, baseada em um instrumento de aplicação simples e com metas individualizadas, pode facilitar sua implementação e disseminação. A construção de uma intervenção preventiva, em grupo e que com objetivos flexíveis é compatível com a praticidade necessária em demandas de saúde pública. A implementação de versões com um (flexibilidade psicológica) ou dois componentes (flexibilidade e cooperação) mostrou que os dois componentes apresentam efeito diferencial: a promoção de flexibilidade levou à realização de metas pessoais, mas a inclusão do modelo prossocial aumentou a interação e a contribuição entre os participantes, além do interesse em prolongar a intervenção. $\mathrm{O}$ monitoramento semanal das metas mostrou o elevado comprometimento dos participantes, um sinal positivo da efetividade da intervenção. Por fim, a promoção de novos comportamentos em diferentes áreas da vida mostra que a intervenção teve alcance transversal. Enfim, estes estudos exploratórios 
reforçam a expectativa de que o argumento estratégico proposto pela $\mathrm{CCC}$ é um chamado para ação promissor (Hayes et al., 2012).

A segunda contribuição se refere à aplicação da CCC como guia para o desenvolvimento de uma intervenção de EPA. A própria natureza preventiva desta intervenção é uma característica distintiva. Considerando os 144 estudos clínicos baseados em ACT e publicados entre 1986 e 2015, por exemplo, apenas sete mencionam prevenção de desfechos negativos ou promoção em saúde mental nos títulos (ACBS Publications, 2016). E não há registros de estudos clínicos baseados em ACT ou de publicações afins à CCC que abordam o ajustamento à aposentadoria (ACBS Publications, 2016). Além disso, a mensuração do resultado por meio do registro diário de comportamentos, e não por entrevistas ou escalas, é inédita entre intervenções de preparação para a aposentadoria (Leandro-França et al., 2016). Portanto, a ciência da prevenção e a prática de preparação para a aposentadoria também podem se beneficiar da estrutura e do pensamento contextual da CCC.

Por fim, a terceira contribuição se refere à avaliação da validade social da intervenção. Embora a validação social possa favorecer a adoção e a disseminação de uma intervenção, o tema é incomum no contexto da aposentadoria. Entre os 11 estudos de preparação para a aposentadoria revisados por Leandro-França et al. (2016), a validade social não foi abordada em nenhum dos casos. Ao todo, somente cinco estudos avaliaram a percepção de satisfação, e apenas três realizaram levantamento prévio de necessidades. Por outro lado, a relevância da validade social é clara: a efetividade de uma intervenção não é suficiente para assegurar sua aceitação pelos usuários, assim como intervenções igualmente efetivas podem não ser igualmente aceitas (Carter, 2010). Embora a validade social não seja suficiente para garantir os resultados, ela é um 
requisito importante para a implementação e disseminação de uma intervenção em ambiente natural.

A intervenção avaliada neste estudo também apresenta duas limitações importantes. A primeira se refere à independência do avaliador: programas preventivos cujas avaliações são realizadas pelos próprios criadores do programa tendem a produzir resultados mais favoráveis (Eisner, 2009). Em função das condições de realização dos estudos, no entanto, a avaliação externa era inviável. A segunda limitação importante se refere à ausência de avaliação de follow-up para verificar a validade social dos efeitos. Embora a avaliação de efetividade exceda o objetivo destes estudos-piloto, intervenções preventivas devem conduzir pelo menos um follow-up de longo prazo para avaliar a manutenção dos resultados (Flay et al., 2005). Portanto, a estabilidade dos novos comportamentos não foi avaliada.

A partir das conclusões que os três casos analisados embasam, é possível delinear alguns próximos passos para a pesquisa sobre desenvolvimento de intervenções para preparação para a aposentadoria. Os resultados foram promissores, ensejando a realização de avaliações de eficácia para testar com rigor o potencial da intervenção para promover compromisso com os valores pessoais. Pensando em uma perspectiva de saúde pública, a etapa de seleção dos participantes deve ser realizada de maneira sistemática pelos pesquisadores, minimizando o viés amostral e favorecendo a validade externa nos dados. Para favorecer qualidade da implementação, permitindo uma mensuração confiável dos efeitos, é importante trabalhar com grupos fechados. Considerando os benefícios da coesão e da cooperação para a eficácia do grupo, é importante avaliar a contribuição diferencial do modelo prossocial para a qualidade e a manutenção dos efeitos. Por fim, avaliar moderadores e mediadores, como a coesão 
grupal e a flexibilidade psicológica, em estudos de eficácia pode esclarecer as características do contexto que interferem no funcionamento da intervenção.

A produção de conhecimento sólido e socialmente relevante pode favorecer o desenvolvimento científico e social. A CCC apresenta uma estratégia que organiza e dá sentido ao conhecimento disponível, o que parece retroagir favoravelmente sobre a qualidade do novo conhecimento produzido. E a validade social complementa esse processo, atribuindo mais sentido à pesquisa. Para muitos que vivenciam o mundo acadêmico, a discrepância entre o esforço envolvido na produção de conhecimento e seu baixo impacto social é frustrante. A avaliação da validade social pode funcionar como um indicativo desse risco, sinalizando com antecedência a receptividade a uma nova intervenção. Em princípio, isso permitiria modificações que favorecem a disseminação da intervenção, completando o ciclo da pesquisa em prevenção e promoção em saúde mental e promovendo qualidade de vida. 


\section{Referências}

ACBS Publications (2016). Association for Contextual Behavioral Science. Retirado de https://contextualscience.org/publications

Baer, D. M., \& Wolf, M. M. (1987). Some still-current dimensions of applied behavior analysis. Journal of Applied Behavior Analysis, 20(4), 313-327. doi:

10.1901/jaba.1987.20-313

Barbosa, L. M., Monteiro, B., \& Murta, S. G. (2016). Retirement adjustment predictors - A systematic review. Work, Aging and Retirement. Publicação online. waw008. doi: 10.1093/workar/waw008

Barbosa, L. M., \& Murta, S. G. (2014). Terapia de aceitação e compromisso: História, fundamentos, modelo e evidências. Revista Brasileira de Terapia Comportamental e Cognitiva, 16(3), 34-49.

Bartholomew, L. K., \& Mullen, P. D. (2011). Five roles for using theory and evidence in the design and testing of behavior change interventions. Journal of Public Health Dentistry, 71, Suppl 1, S20-S33. doi: 10.1111/j.1752-7325.2011.00223.x

Berkel, C., Mauricio, A. M., Schoenfelder, E., \& Sandler, I. N. (2011). Putting the pieces together: An integrated model of program implementation. Prevention Science, 12, 23-33.

Biglan, A., Ciarrochi, J., Hayes, S. C., Holnick, A., Miller, J., Polk, K., \& Wilson, D. S. (2014). Training and Assessment Manual for PROSOCIAL Group Facilitators. Retirado de http://www.prosocialgroups.org/

Biglan, A., \& Hayes, S. C. (1996). Should the behavioral sciences become more pragmatic? The case for functional contextualism in research on human behavior. 
Applied \& Preventive Psychology, 5, 47-57.

Bonsang, E., \& Klein, T. J. (2012). Retirement and subjective well-being. Journal of Economic Behavior \& Organization, 83(3), 311-329. doi:

10.1016/j.jebo.2012.06.002

Braun, V., \& Clarke, V. (2006). Using thematic analysis in psychology. Qualitative Research in Psychology, 3, 77-101. doi: 10.1191/1478088706qp063oa

Budd, R., \& Hughes, I. (2009). The dodo bird veredict - Controversial, inevitable and important: A commentary on 30 years of meta-analyses. Clinical Psychology and Psychotherapy, 16, 510-522. doi: 10.1002/cpp

Carter, S. L. (2010). The social validity manual. San Diego, CA: Academic Press.

Ciarrochi, J., \& Bailey, A. (2008). A CBT-Practitioner's Guide to ACT: How to bridge the gap between cognitive behavioral therapy and acceptance and commitment therapy. Oakland, CA: New Harbinger Publications, Inc.

Durlak, J. A., \& DuPre, E. P. (2008). Implementation matters: A review of research on the influence of implementation on program outcomes and the factors affecting implementation. American Journal of Community Psychology, 41, 327-350. doi: $10.1007 / \mathrm{s} 10464-008-9165-0$

Eisner, M. (2009). No effects in independent prevention trials: Can we reject the cynical view? Journal of Experimental Criminology, 5(2), 163-183. doi: 10.1007/s11292009-9071-y

Fawcett, S. B. (1991). Social validity: A note on methodology. Journal of Applied Behavior Analysis, 24(2), 235-9. doi: 10.1901/jaba.1991.24-235

Flay, B. R., Biglan, A., Boruch, R. F., Castro, F. G., Gottfredson, D., Kellam, S., ... Ji, 
P. (2005). Standards of evidence: Criteria for efficacy, effectiveness and dissemination. Prevention Science, 6(3), 151-175.

Frögéli, E., Djordjevic, A., Rudman, A., Livheim, F., \& Gustavsson, P. (2016). A randomized controlled pilot trial of acceptance and commitment training (ACT) for preventing stress-related ill health among future nurses. Anxiety, Stress, and Coping, 29, 202-218. doi: 10.1080/10615806.2015.1025765.

Hayes, S. C., Barnes-Holmes, D., \& Roche, B. (2001). Relational frame theory - A postskinnerian account of human language and cognition. New York: Kluwer Academic/Plenum Publishers.

Hayes, S. C., Barnes-Holmes, D., \& Wilson, K. G. (2012). Contextual behavioral science: Creating a science more adequate to the challenge of human condition. Journal of Contextual Behavioral Science. doi: 10.1016/j.jcbs.2012.09.004

Hayes, S. C., \& Brownstein, A. J. (1986). Mentalism, behavior-behavior relations, and a behavior-analytic view of the purposes of science. The Behavior Analyst, 9, 175190.

Hayes, S. C., Hayes, L. J., \& Reese, H. W. (1988). Finding the philosophical core: A review of Stephen C. Pepper's world hypotheses: A study in evidence. Journal of the Experimental Analysis of Behavior, 50(1), 97-111.

Hayes, S. C., Long, D. M., Levin, M. E., \& Follette, W. C. (2013). Treatment development: Can we find a better way? Clinical Psychology Review, 33(7), 87082. doi: 10.1016/j.cpr.2012.09.009

Hayes, S. C., Luoma, J. B., Bond, F. W., Masuda, A., \& Lillis, J. (2006). Acceptance and commitment therapy: Model, processes and outcomes. Behaviour Research 
and Therapy, 44(1), 1-25.

Hayes, S. C., Strosahl, K. D., \& Wilson, K. G. (2012). Acceptance and Commitment Therapy: The process and practice of mindful change ( $2^{\mathrm{a}}$ ed.). New York: Guilford Press.

Herbert, J. D., Gaudiano, B. A., \& Forman, E. M. (2013). The Importance of Theory in Cognitive Behavior Therapy: A Perspective of Contextual Behavioral Science. Behavior Therapy. doi: 10.1016/j.beth.2013.03.001

Kämpfen, F., \& Maurer, J. (2016). Time to burn (calories)? The impact of retirement on physical activity among mature Americans. Journal of Health Economics, 45, 91102. doi: 10.1016/j.jhealeco.2015.12.001

Kanter, J. W., Busch, A. M., \& Rusch, L. C. (2009). Behavioral activation: Distinctive features. New York: Routledge.

Lane, K. L., \& Beebe-Frankenberger, M. (2004). Social validity: Goals, procedures, and outcomes. In School-based interventions - The tools you need to succeed (pp. 85127). Boston: Pearson.

Laska, K. M., Gurman, A. S., \& Wampold, B. E. (2014). Expanding the lens of evidence-based practice in psychotherapy: A common factors perspective. Psychotherapy, 51(4), 467-481. doi: 10.1037/a0034332

Leandro-França, C., Giardini Murta, S., Hershey, D. A., \& Barbosa, L. M. (2016). Evaluation of retirement planning programs: A qualitative analysis of methodologies and efficacy. Educational Gerontology, 1-16. doi: $10.1080 / 03601277.2016 .1156380$

Lewin, K. (1951). Problems of research in social psychology. In D. Cartwright (Ed.), 
Field theory in social science: Selected theoretical papers (pp. 155-169). New York, NY: Harper \& Row.

Muñoz, R. F., Mrazek, P. J., \& Haggerty, R. J. (1996). Institute of Medicine Report on Prevention of Mental Disorders. American Psychologist, 51(11), 1116-1122.

Murta, S. G., Moura, S. A., França, C. L., Pedralho, M., Seidl, J., Lira, N. de P. M., ... Gunther, I. de A. (2014). Preparação para a aposentadoria: Implementação e avaliação do programa Viva Mais! Revista Psicologia: Reflexão E Crítica, 27(1), 1-9. doi: 10.1590/S0102-79722014000100001

Murta, S. G., \& Santos, K. B. dos. (2015). Desenvolvimento de programas preventivos e de promoção em saúde mental. In S. G. Murta, C. Leandro-França, K. B. dos Santos, \& L. Polejack (Eds.), Prevenção e promoção em saúde mental: Fundamentos, planejamento e estratégias de intervenção (pp. 168-191). Novo Hamburgo: Sinopsys.

Nimrod, G., Janke, M. C., \& Kleiber, D. A. (2008). Retirement, activity, and subjective well-being in lsrael and the Unites States. World Leisure, 1, 18-32. doi: $10.1080 / 04419057.2008 .9674524$

Pepper, S. C. (1942). World hypotheses: A study in evidence. Berkeley: University of California.

Polk, K., \& Schoendorff, B. (2014). The ACT Matrix: A new approach to building psychological flexibility across settings and populations. Oakland, CA: Context Press.

Rohrbach, L. A. (2014). Design of prevention interventions. In Z. Sloboda \& H. Petras (Eds.), Defining prevention science (pp. 275-291). New York: Springer. 
Santos, K. B. dos, \& Murta, S. G. (2015). A implementação de programas de prevenção e promoção no âmbito da saúde mental. In S. G. Murta, C. Leandro-França, K. B. dos Santos, \& L. Polejak (Eds.), Prevenção e promoção em saúde mental: Fundamentos, planejamento e estratégias de intervenção (pp. 192-211). Novo Hamburgo: Sinopsys.

Szinovacz, M. E., \& Davey, A. (2001). Retirement Effects on Parent-Adult Child Contacts. The Gerontologist, 41(2), 191. doi: 10.1093/geront/41.2.191

Szinovacz, M. E., \& Davey, A. (2005). Retirement and marital decision making: Effects on retirement satisfaction. Journal of Marriage and Family, 67(2), 387-398. doi: $10.1111 / \mathrm{j} .0022-2445.2005 .00123 . \mathrm{x}$

van der Heide, I., van Rijn, R. M., Robroek, S. J. W., Burdorf, A., \& Proper, K. I. (2013). Is retirement good for your health? A systematic review of longitudinal studies. BMC Public Health, 13, 1180. doi: 10.1186/1471-2458-13-1180

Vilardaga, R., Hayes, S. C., Levin, M. E., \& Muto, T. (2009). Creating a strategy for progress: A contextual behavioral science approach. The Behavior Analyst, 32(1), 105-33.

Wang, M., Henkens, K., \& van Solinge, H. (2011). Retirement adjustment: A review of theoretical and empirical advancements. The American Psychologist, 66(3), 20413. doi: $10.1037 / \mathrm{a} 0022414$

Wilson, D. S. (2012). Consilience: Making contextual behavioral science part of the united ivory archipelago. Journal of Contextual Behavioral Science, 1(1-2), 39-42. doi: $10.1016 /$ j.jcbs.2012.09.005

Wilson, D. S., Kauffman, R. A, \& Purdy, M. S. (2011). A program for at-risk high 
school students informed by evolutionary science. PloS One, 6(11), e27826. doi: 10.1371/journal.pone.0027826

Wilson, D. S., Ostrom, E., \& Cox, M. E. (2013). Generalizing the core design principles for the efficacy of groups. Journal of Economic Behavior \& Organization, 90, S21-S32. doi: 10.1016/j.jebo.2012.12.010

Wilson, K. G., Sandoz, E. K., Kitchens, J., \& Roberts, M. (2010). The valued living questionnaire: Defining and measuring valued action within a behavioral framework. The Psychological Record, 60, 249-272.

Wolf, M. M. (1978). Social validity: The case for subjective measurement or how applied behavior analysis is finding its heart. Journal of Applied Behavior Analysis, 11(2), 203-214. doi: 10.1901/jaba.1978.11-203

Yin, R. K. (2013). Case Study Research: Design and Methods (5ª ed.). Thousand Oaks, CA: Sage. 